\begin{tabular}{|c|c|}
\hline $\begin{array}{l}\text { IAN } 61990 \% \text { ENGINEERING DATA TRANSMITTAL } \\
\text { Sta, } 37 \text {, }\end{array}$ & 1. Е०T 622747 \\
\hline
\end{tabular}

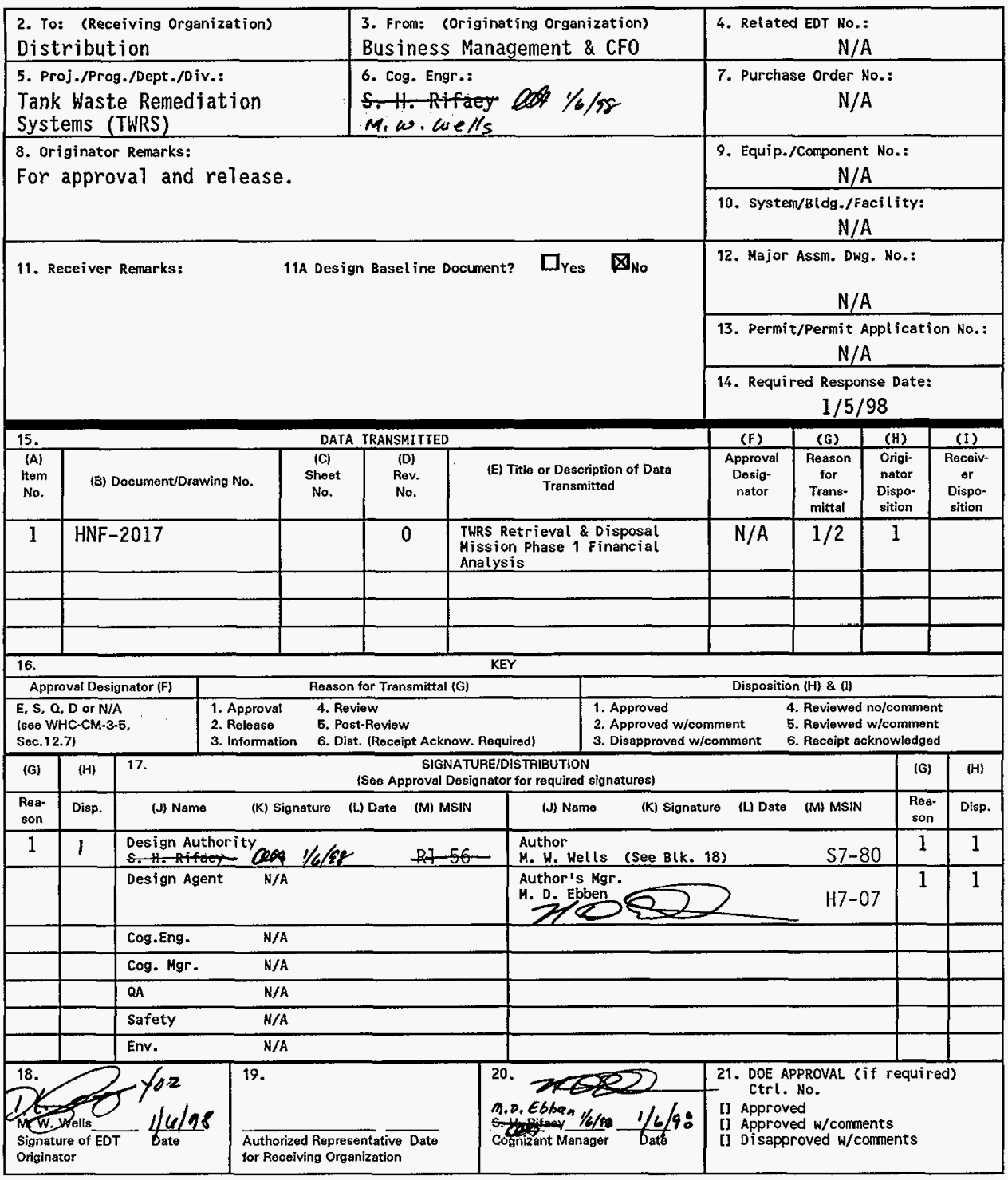




\title{
Tank Waste Remediation System Retrieval and Disposal Mission Phase 1 Financial Analysis
}

\author{
M.W. We11s \\ Lockheed Martin Hanford Company, Richland, WA 99352 \\ U.S. Department of Energy Contract DE-AC06-96RL13200
}

EDT/ECN: $622747 \quad$ UC: 2030

Org Code: $72200 \quad$ Charge Code: D215P

B\&R Code: EW3130010 Total Pages: 112 fea

Key Words: TWRS, Retrieval and Disposal Mission, Phase 1,Financial Analysis

Abstract: The purpose of the Tank Waste Retrieval and Disposal Mission Phase 1 Financial Analysis is to provide a third-party quantitative and qualitative cost and schedule risk analysis of HNF-1946.

TRADEMARK DISCLAIMER. Reference herein to any specific comercial product, process, or service by trade name, tradenark, manufacturer, or otherwise, does not necessarily constitute or imply its endorsement, recommendation, or favoring by the United States Government or any agency thereof or its contractors or subcontractors.

Printed in the United States of America. To obtain copies of this document, contact: Document Control Services, P.0. Box 950, Mailstop H6-08, Richland WA 99352, Phone (509) 372-2420;

Fax (509) 376-4989.
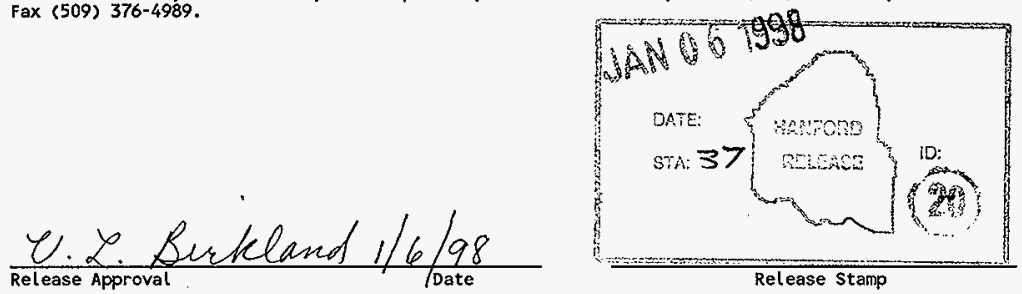


\section{Tank Waste Remediation System Retrieval and Disposal Mission Phase 1 Financial Analysis}

M. W. Wells

Lockheed Martin Hanford Corporation

Date Published

January 1998

Prepared by Lockheed Martin Hanford Corporation

Richland, Washington

Prepared for the U.S. Department of Energy

Fluor Daniel Hanford, Inc.

P.O. Box 1000

Richland, Washington

Hanford Management and Integration Contractor for the

U.S. Department of Energy under Contract DE-AC-0696-RL13200 
HNF-2017 Rev 0

This page intentionally left blank. 
HNF-2017 Rev 0

Document Title: $\quad$ Tank Waste Remediation System Retrieval and Disposal Mission Phase 1 Financial Analysis

Approved by:
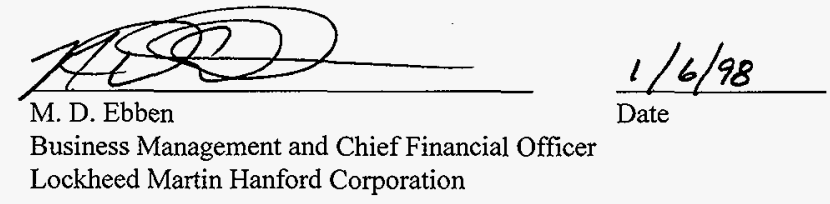

Date

Business Management and Chief Financial Officer Lockheed Martin Hanford Corporation 
HNF-2017 Rev 0

This page intentionally left blank. 


\section{CONTENTS}

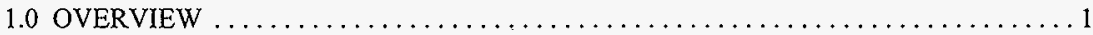

2.0 APPROACH $\ldots \ldots \ldots \ldots \ldots \ldots \ldots \ldots \ldots \ldots \ldots \ldots \ldots \ldots \ldots \ldots \ldots \ldots \ldots \ldots$

2.1 BASELINE DEVELOPMENT APPROACH $\ldots \ldots \ldots \ldots \ldots \ldots \ldots \ldots \ldots 7$

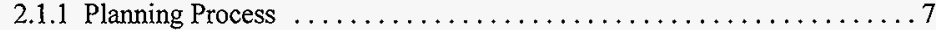

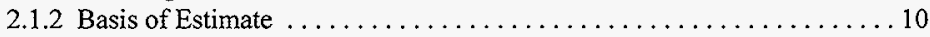

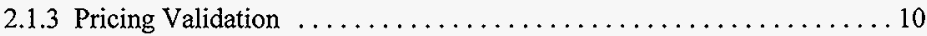

2.2 FINANCIAL RISK ANALYSIS APPROACH - PHASE $1 \mathrm{~B} \ldots \ldots \ldots \ldots \ldots \ldots 12$

2.2.1 Technical Basis Review Risk Assessment Process . . . . . . . . . . . 12

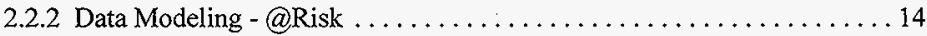

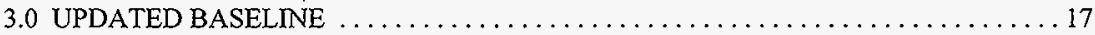

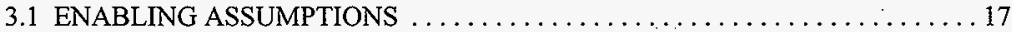

3.2 BASELINE DESCRIPTION $\ldots \ldots \ldots \ldots \ldots \ldots \ldots \ldots \ldots \ldots \ldots \ldots \ldots \ldots 17$

3.3 TIME PHASED COST BY PROJECT BASELINE SUMMARY $\ldots \ldots \ldots \ldots 18$

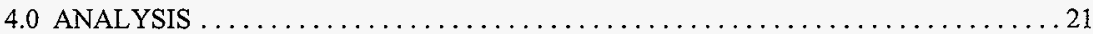

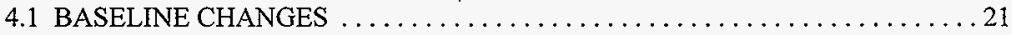

4.1.1 Phase 1B Scope Not in Logics . . . . . . . . . . . . . . . 21

4.1.2 Updated Baseline to Meet Critical Path . . . . . . . . . . . 22

4.1.3 Other TWRS Phase 1B Support . . . . . . . . . . . . . . . . . 22

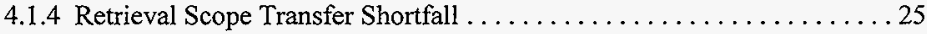

4.2 RISK ANALYSIS - PHASE 1B - PROJECT SPECIFIC . . . . . . . . . 27

4.2.1 High-Level Waste Feed Delivery Risk Analysis . . . . . . . . . . . 30

4.2.2 Low-Activity Waste Feed Delivery Risk Analysis . . . . . . . . . . 31

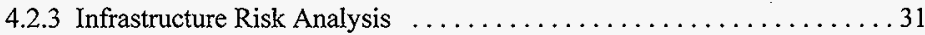

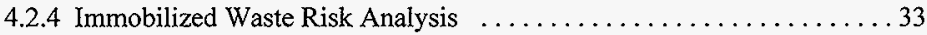

4.3 RISK ANALYSIS - PHASE $1 B$ - INTEGRATED PROJECT $\ldots \ldots \ldots \ldots \ldots$

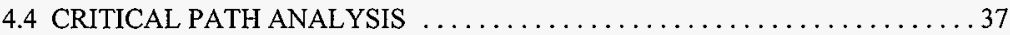

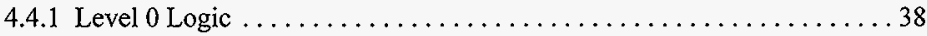

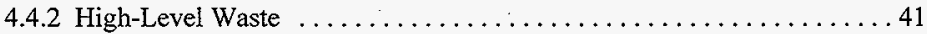

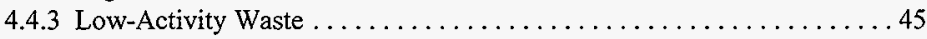

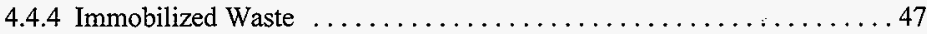

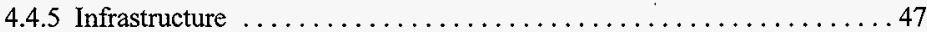

4.5 PROGRAMMATIC RISKS $\ldots \ldots \ldots \ldots \ldots \ldots \ldots \ldots \ldots \ldots \ldots \ldots \ldots \ldots \ldots$

4.6 FY 1998 AND FY 1999 TARGET FUNDING ANALYSIS . . . . . . . . . . 51

4.7 COST REDUCTION OPPORTUNITIES $\ldots \ldots \ldots \ldots \ldots \ldots \ldots \ldots \ldots \ldots \ldots$

4.8 COMMON OCCUPATIONAL CODE STRUCTURE ANALYSIS $\ldots \ldots \ldots \ldots 53$

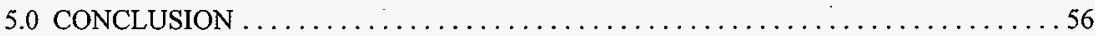


HNF-2017 Rev 0

CONTENTS (Continued)

6.0 REFERENCES 60

\section{APPENDICES}

A FINANCIAL DETAILS $\ldots \ldots \ldots \ldots \ldots \ldots \ldots \ldots \ldots \ldots \ldots \ldots \ldots \ldots \ldots \ldots \ldots \ldots$

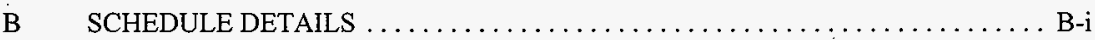

C GUIDANCE AND REQUIREMENTS TO DELIVERABLES CROSSWALK TWRS RETRIEVAL AND DISPOSAL MISSION PHASE 1 FINANCIAL

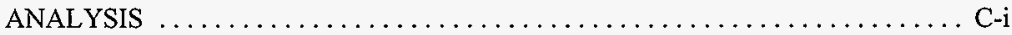




\section{LIST OF FIGURES}

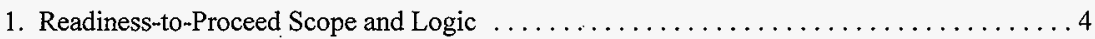

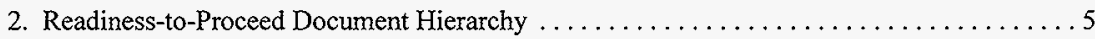

3. Lockheed Martin Hanford Corporation Integrated Baseline Development Model . . . . . 8 8

4. Tank Waste Remediation System Top Level Document Relationships .............9

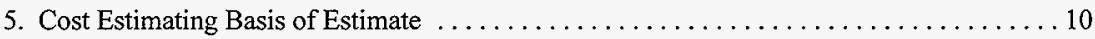

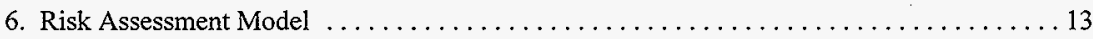

7. Readiness-to-Proceed cost Profile by Project Baseline Summary $\ldots \ldots \ldots \ldots \ldots \ldots$

8. Phase 1B to Multi-Year Work Plan Baseline cumulative cost Comparison ........... 23

9. Phase 1B to Multi-Year Work Plan Baseline Cost Comparison . . . . . . . . . . . 24

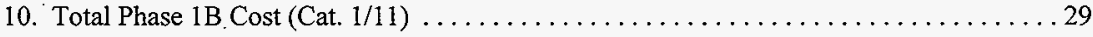

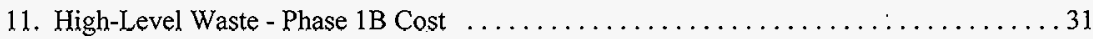

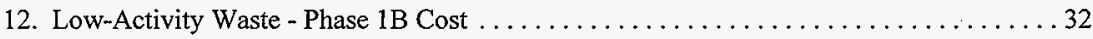

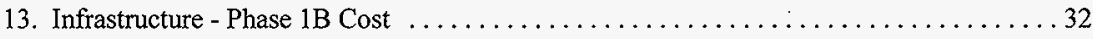

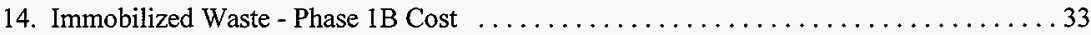

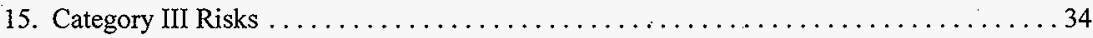

16. Tank Waste Remediation System Program Logic ......................... 39

17. Readiness-to-Proceed Site Master Baseline Schedule $\ldots \ldots \ldots \ldots \ldots \ldots \ldots \ldots 42$

18. High-Level Waste Batches 1 and 2 Critical Path Schedule $\ldots \ldots \ldots \ldots \ldots \ldots \ldots$

19. Low-Activity Waste Batch 1 Critical Path Schedule $\ldots \ldots \ldots \ldots \ldots \ldots \ldots \ldots$

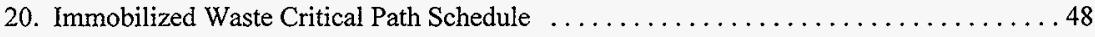

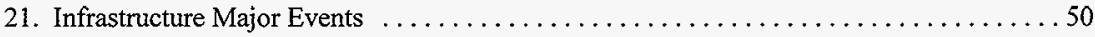




\section{LIST OF FIGURES (Continued)}

22. Phase 1B Resource-Load Schedules by Common Occupational Code Structure

55

\section{LIST OF TABLES}

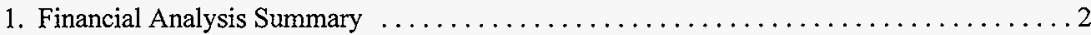

2. Update Phase $1 \mathrm{~B}$ Baseline. ................................. 18

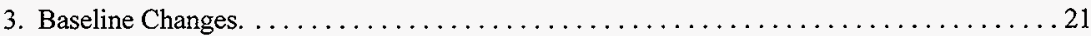

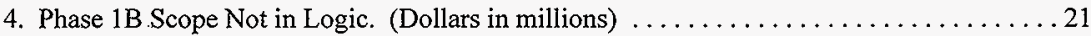

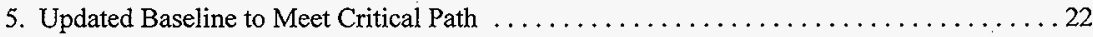

6. Other Tank Waste Remediation System Phase 1B Support Scope $\ldots \ldots \ldots \ldots \ldots \ldots 25$

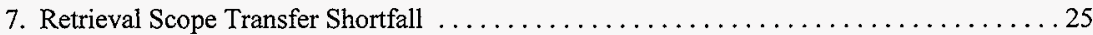

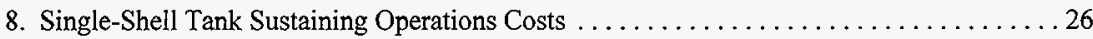

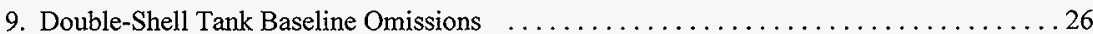

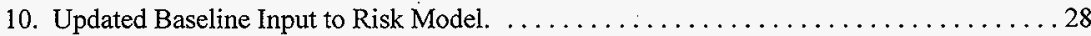

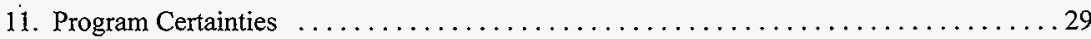

12. Time Phasing of Project Specific Risk Allocations. .................... 30

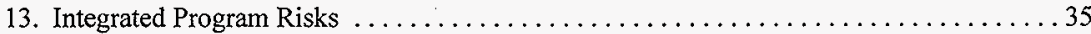

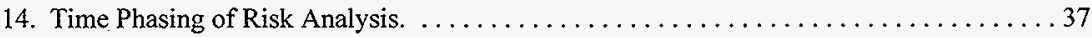

15. Critical Path Analysis Risk Allowance $\ldots \ldots \ldots \ldots \ldots \ldots \ldots \ldots \ldots \ldots \ldots \ldots \ldots \ldots \ldots \ldots$

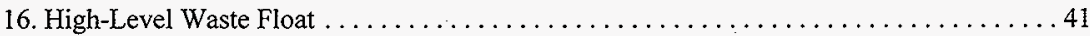

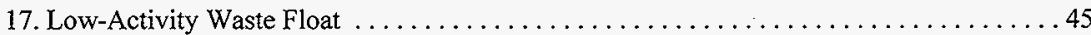


HNF-2017 Rev 0

\section{LIST OF TABLES (Continued)}

18. Fiscal Year 1998 and Fiscal Year 1999 Summary ..................... 51

19. Updated FY 1998 - FY 1999 Baseline to Meet Critical Path. .................52

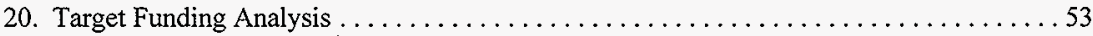

21. Pre-Phase $1 \mathrm{~B}$ Analysis Budget Requirements Increases $\ldots \ldots \ldots \ldots \ldots \ldots \ldots 6$

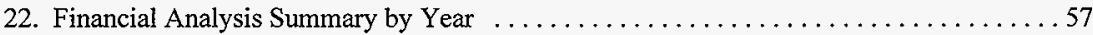


HNF-2017 Rev 0

\section{LIST OF TERMS}

CEIS

DOE

DST

Ecology

EPA

ES\&H

FDH

FY

HLW

IHLW

ILAW

LAW

LMHC

MYWP

PBS

PHMC

RTP

SST

TBR

TWRS

USQ

WBS

WIT cost estimating input sheet

U.S. Department of Energy

double-shell tank

Washington State Department of Ecology

U.S. Environmental Protection Agency

environment, safety, and health

Fluor Daniel Hanford, Inc.

fiscal year

high-level waste

immobilized high-level waste

immobilized low-activity waste

low-activity waste

Lockheed Martin Hanford Corporation

multi-year work plan

Project Baseline Summary

Project Hanford Management Contract

readiness to proceed

single-shell tank

technical basis review

Tank Waste Remediation System

unreviewed safety question

work breakdown structure

Waste Integration Team 


\section{TANK WASTE REMEDIATION SYSTEM \\ RETRIEVAL AND DISPOSAL MISSION \\ PHASE 1 FINANCIAL ANALYSIS}

\subsection{OVERVIEW}

The purpose of the Tank Waste Remediation System (TWRS) Retrieval and Disposal Mission Phase 1 Financial Analysis is to provide a quantitative and qualitative cost and schedule risk analysis of HNF-1946, Tank Waste Remediation System Retrieval and Disposal Mission Initial Updated Baseline (Swita et al. 1998). The Updated Baseline (Section 3.0) is compared to the current TWRS Project Multi-Year Work Plan (MYWP) for fiscal year (FY) 1998 and target budgets for FY 1999 through FY 2011 (Section 4.1). The analysis then evaluates the executability of HNF-1946 (Swita et al. 1998) (Sections 4.2 through 4.5) and recommends a path forward for risk mitigation (Sections $4.6,4.7$, and 5.0).

A sound systems engineering approach was applied to understand and analyze the Phase 1B Retrieval and Disposal mission. Program and Level 1 Logics were decomposed to Level 8 of the Work Breakdown Structure (WBS) where logic was detailed, scope was defined, detail durations and estimates prepared, and resource loaded schedules developed. Technical Basis Review (TBR) packages were prepared which include this information and, in addition, defined the enabling assumptions for each task, and the risks associated with performance. This process is discussed in Section 2.1.

Detailed reviews at the subactivity within the Level 1 Logic TBR levels were conducted to provide the recommended solution to the Phase 1B Retrieval and Disposal Mission. Independent cost analysis and risk assessments were performed by members of the Lockheed Martin Hanford Corporation (LMHC) Business Management and Chief Financial Officer organization along with specialists in risk analysis from TRW, Inc. and Lockheed Martin Energy Systems. The process evaluated technical, schedule, and cost risk by category (program specific fixed and variable, integrated program, and programmatic) based on risk certainty from high probability well defined to very low probability that is not bounded or priceable as discussed in Section 2.2. The results have been modeled using a Monte Carlo type simulation and are included in Section 4.0 Analysis. The modeling was focused on low-activity waste (LAW) and high-level waste (HLW) feed delivery, infrastructure, and immobilized waste storage and disposal, and compiled at the total Phase 1B Retrieval and Disposal program.

An independent review appraisal of technical plans and processes was also conducted utilizing experienced senior personnel both active and retired from Fluor Daniel Hanford, Inc. (FDH), Lockheed Martin Hanford Corporation, U.S. Department of Energy (DOE), and previous Hanford contractors. 
The results were merged with the output from other evaluations to form HNF-1945, Tank Waste Remediation System Retrieval and Disposal Mission Key Enabling Assumptions (Baldwin et al. 1998), and the Tank Waste Remediation System Retrieval and Disposal Critical Risk List as identified in HNF-2019, Tank Waste Remediation System Retrieval and Disposal Mission Readiness-to-Proceed Memorandum (Boston and Jordan 1998), which support the basis of this analysis.

A detailed analysis (Section 4.0) of the overall costs to prepare for and perform the Project Hanford Management Contractor (PHMC) team portion of Phase 1B was completed. In general, the updated TWRS cost baseline for the period FY 1998 through FY 2011 is $\$ 5.4$ billion or $\$ 458$ million above (less than $10 \%$ ) the current target baseline. The Phase 1B Retrieval and Disposal portion of the $\$ 5.4$ billion is $\$ 2.4$ billion as shown in Table 1 . The risk analysis suggests an execution probability of $80 \%$ at this value. The $\$ 458$ million in growth consists of approximately $\$ 210$ million in scope adjustments shown by an asterisk on Table 1 and an allowance for risk of $\$ 248$ million to increase the program certainty to $80 \%$. Some near-term noncritical path adjustments of $\$ 5$ million in FY 1998 and $\$ 10$ million of additional funds in FY 1999 are required to ensure retrieval and disposal critical path activities are fully funded (Section 4.6).

Table 1. Financial Analysis Summary.

\begin{tabular}{|l|r|r|}
\hline & $\begin{array}{c}\text { Retrieval and } \\
\text { disposal } \\
\text { (millions) }\end{array}$ & $\begin{array}{c}\text { TWRS } \\
\text { (millions) }\end{array}$ \\
\hline Budget Requirements (MYWP) & $\$ 1857$ & $\$ 4954$ \\
- Existing Shortfall (Section 4.6) & -- & $13 *$ \\
Budget Requirements (Pre-Analysis) & 1857 & 4967 \\
- Updated baseline to meet critical path (Section 4.1.2) & 159 & $159 *$ \\
Updated Phase 1B Baseline & $\$ 2016$ & $\$ 5126$ \\
- Retrieval Scope Transfer Shortfall (Section 4.1.4) & 46 & $46 *$ \\
Subtotal & 2062 & 5172 \\
- Other TWRS Phase 1B Support (Section 4.1.3) & 117 & -- \\
Requirements & 2179 & 5172 \\
- Allowances for Risk (Section 4.2 and Section 4.3) & 248 & 248 \\
Requirements @ 80\% Certainty & 2427 & 5420 \\
- Recommended Actions (Section 4.6) & -- & $(8) *$ \\
Updated Budget Requirements & $\$ 2427$ & $\$ 5412$ \\
\hline Total Added Requirements (Section 5.0) & & $\$ 458$ \\
Cost Reduction Opportunities (Section 4.7). & & $\$(200)$ \\
\hline
\end{tabular}

*Scope adjustments equaling $\$ 210$ million.

MYWP = multi-year work plan.

TWRS $=$ Tank Waste Remediation System. 
Cost reduction opportunities (Section 4.7) have been identified which could partially offset the $\$ 458$ million growth and the known risks. These include the impacts of FDHsponsored reductions in site indirect and benefits program costs of $\$ 140$ million and realization of Enterprise Resource Planning system-related efficiencies of $\$ 60$ million.

Both HNF-1946 (Swita et al. 1998) and this Financial Analysis have been developed as a part of the PHMC team's assessment in support of HNF-2021, Management Assessment of Tank Waste Remediation System Contractor Readiness to Proceed with Phase 13 Privatization (Payne et al. 1998). Figure 1, Readiness-to-Proceed Scope and Logic, shows how the Financial Analysis fits in the overall readiness-to-proceed (RTP) process. Figure 2, Readiness-to-Proceed Document Hierarchy, identifies the top-down flow of Tank Waste Retrieval and Disposal documents related to RTP including HNF-1946 (Swita et al. 1998) and the Financial Analysis. 
Figure 1. Readiness-to-Proceed Scope and Logic.

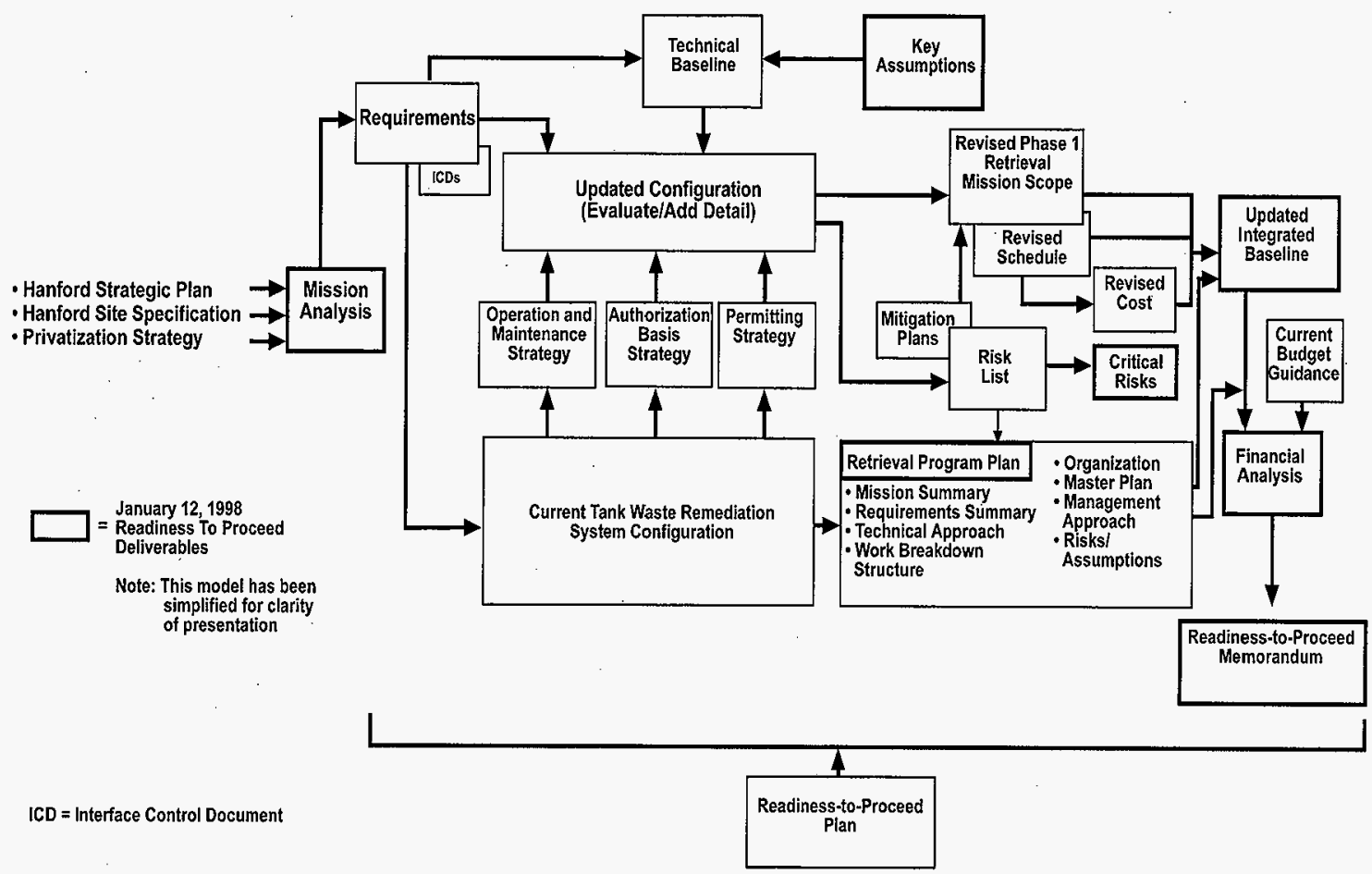


HNF-2017 Rev 0

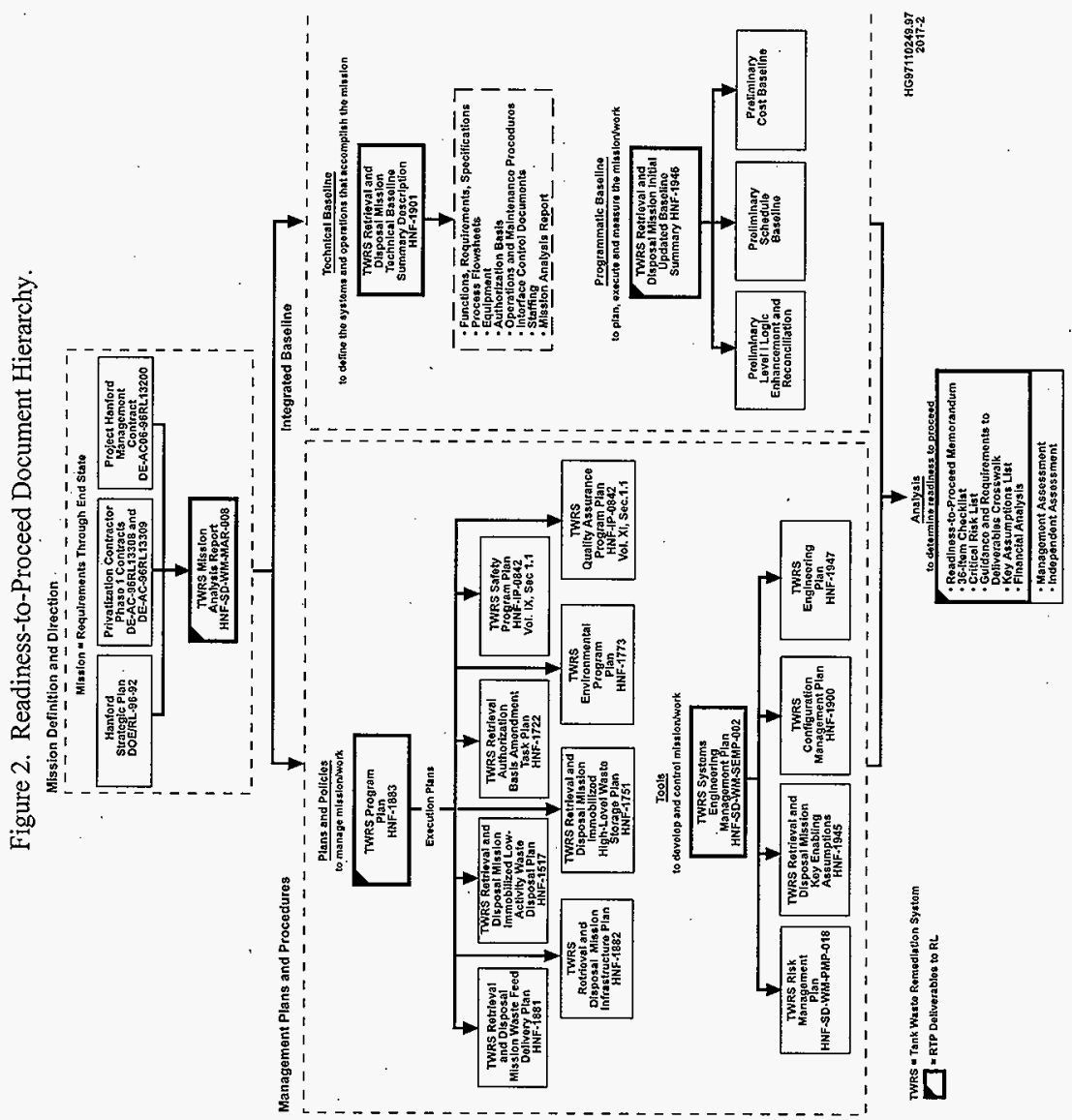


HNF-2017 Rev 0

This page intentionally left blank. 


\subsection{APPROACH}

This section is a brief description of the Baseline Development Approach used for RTP including the planning process, basis of estimate and pricing validation. The financial and programmatic risk analysis approach is also described including data development/collection, assessment and probabilistic modeling using the @ Risk ${ }^{1}$ software.

\subsection{BASELINE DEVELOPMENT APPROACH}

This section includes a discussion of the planning, estimating, and cost validation processes employed in this analysis.

\subsubsection{Planning Process}

The planning process used to develop HNF-1946 (Swita et al. 1998) is based on Figure 3, LMHC Integrated Baseline Development Model. This Model is fully integrated with Figure 4, TWRS Top Level Document Relationships. These products reflect a systems engineering management approach to top-down development of requirements and technical scope which define the WBS, logics, schedules and costs necessary for a viable program baseline and MYWP.

Key to preparation of HNF-1946 (Swita et al. 1998) was development of Level 1 Logics and TBR Packages to define scope, schedule and resources necessary to prepare the logic driven, resource loaded, critical path baseline schedules. The WBS and Level 1 Logics are traceable, integrated and coded accordingly in the schedules.

The TBR Packages were developed through the efforts of multi-disciplined RTP planning teams. The TBR packages were built for each Level 1 logic activity with primary activity owners assigned for each Level 1 Logic. The TBR packages consist of TBR sheets, decomposed subactivity logic networks (Level 2 Logic) and cost estimating input sheets (CEIS) for each subactivity. The TBR package components (Level 2 Logic [WBS Level 8]) are activity-based, define the scope of work at an executable task level and provide a well documented basis for the schedule and cost commensurate with the stage of the project work and the level of scope definition available. The data from the TBR packages was used to develop the baseline schedule in Primavera ${ }^{2}$ used for this Financial Analysis. All pricing of resources was done in Primavera. Costs for activities not included in the Level 1 logics were obtained from the FY 1998 MYWP.

${ }^{1}$ @Risk is a trademark of Parker Brothers, Division of Tonka Corporation.

${ }^{2}$ Primavera is a trademark of Primavera Systems, Inc. 
Figure 3. Lockheed Martin Hanford Corporation Integrated Baseline Development Model.

\section{Hanford}

Site

Technical

Database

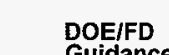

I TWRs

Definition, Waste

| Volume, Project

Traceability$$
\text { 孪 }
$$

Traceability I Integrated

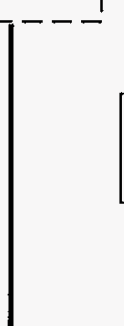

Technical
Summary
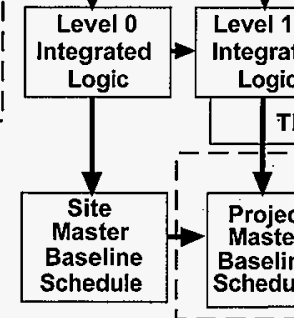

evel 1

Integrated

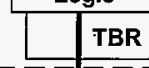

TBR

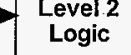

$-=-7--$

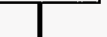

roject

Master

Baseline

L -

Scope,

Schedule

and Cost

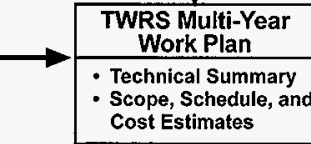

ACWP = Actual Cost of Work Performed

BCWP = Budgeted Cost of Work Perfomed

BCWS = Budgeted Cost of Work Scheduled

DOE = U.S. Department of Energy

FDH = Fluor Daniel Hanford, Inc.

TBR = Technical Basis Reveiw

TWRS = Tank Waste Remediation System

\section{Definitized Contract}

(Execution Year Data)

udget and

Schedule Checks
Multi-Year

Reporting

\footnotetext{
Primavera is a trademark of Primavera Systems, Inc.
} 
Figure 4. Tank Waste Remediation System Top Level Document Relationships.

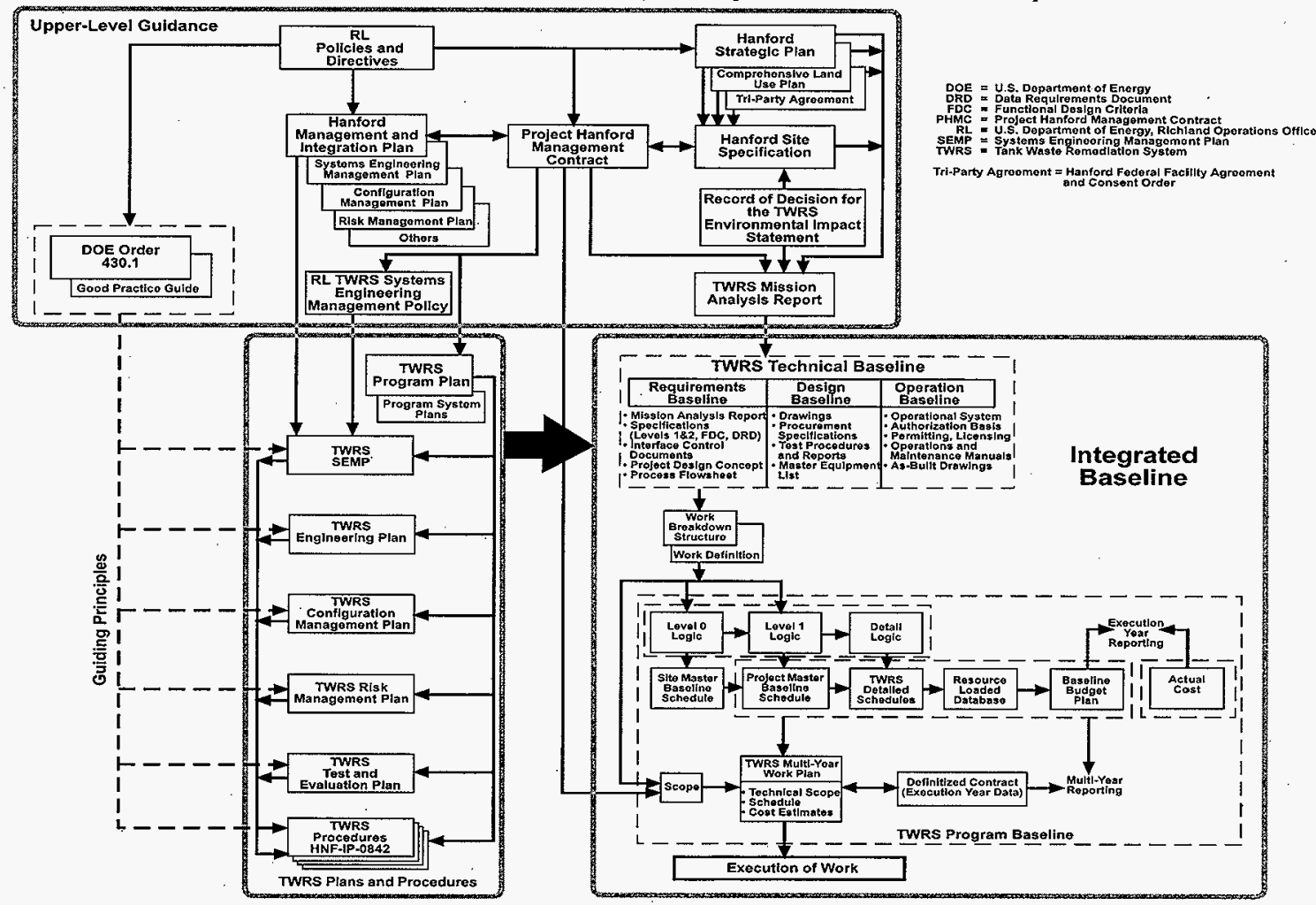


TBR packages were not prepared for activities not in Level 1 logics, such as level-of-effort management and support related activities.

Key to this Financial Analysis is the fact that enabling assumptions, risk issues, risk mitigation actions and estimating assumptions/exclusions/risks for each activity were documented in the TBRs and CEISs. The risk analysis approach was based on this planning input at the TBR level. The data has been similarly used to develop HNF-1945 (Baldwin et al. 1998) and the TWRS Retrieval and Disposal Mission Critical Risk List as identified in HNF-2019 (Boston and Jordan 1998).

\subsubsection{Basis of Estimate}

Figure 5, Cost Estimating Basis of Estimate, provides a summary of how the basis of estimate is developed and utilized in the logic/TBR/baseline development/risk analysis process. Basis of estimates for activities documented in TBR packages are contained in the CEISs which were prepared according to written guidelines and instructions prepared for the RTP assessment. Basis of estimates have been developed to the lowest level of detail practical (generally the executable task Level 8 of the work breakdown structure) commensurate with the stage of the project work and the level of scope definition available. The TBR package estimates have been prepared with integrated planning team support from professional cost estimators and schedulers. Expense funded activities have been estimated using engineering judgement and significant historical experience with similar work. Existing Authorized Line Item Projects were not reestimated; however, costs are based on existing validated baselines. Future projects were estimated based on historical costs for similar efforts adjusted for planned work scope. Other activities not included in the logics are documented in the FY 1998 MYWP and supporting documentation. The pricing of resources specified in the CEIS was accomplished in Primavera using rates and factors approved by FDH and DOE including standard labor rate tables, burdens, pools and assessment factors and escalation as found in HNF-1946 (Swita et al, 1998).

\subsubsection{Pricing Validation}

The bottoms-up estimate prepared for RTP and documented in the TBR packages has been reviewed and approved by members of the multi-disciplined, integrated planning teams. These estimates are bottoms-up, activity based and were prepared with the assistance of professional cost estimators provided by Fluor Daniel Northwest. These estimates and associated schedules have received an independent assessment of risk and Monte Carlo analysis with the support of TRW, Inc. and Lockheed Martin Energy Systems. 
Figure 5. Cost Estimating Basis of Estimate.
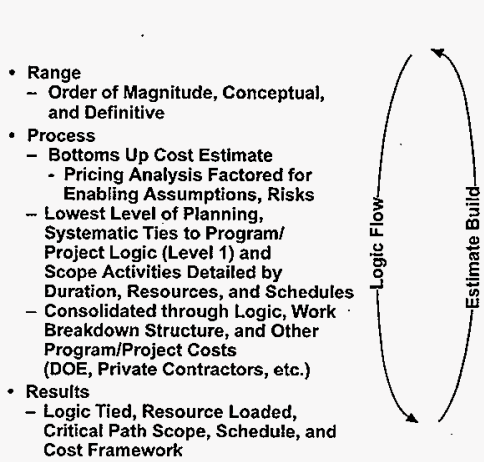

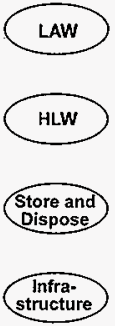

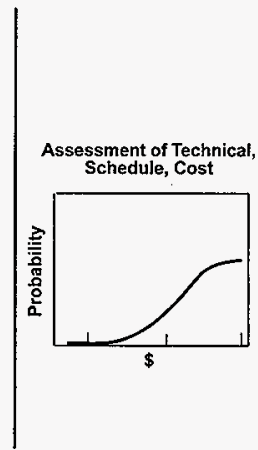

H97110249.119

HLW $=$ High-level waste

LAW = Low-actlvity waste

Existing MYWP cost estimates that have been utilized have received significant review and analysis in recent years. Life Cycle Activity Based Cost estimates were prepared for the entire Tank Waste Remediation System Project and received a favorable Independent Cost Estimate Review and validation by. DOE Headquarters Financial Management Organization (FM-20) in FY 1996. Most recently, FDH has conducted an independent review of the MYWP basis of estimates, without significant findings.

A specific review of the development, estimating, and analysis process was conducted by Lockheed Martin senior management. Comparisons were made to the techniques and rigor applied in development of fixed-price competitive projects. Lessons learned from analyzing other Lockheed Martin DOE and U.S. Department of Defense projects were considered. The estimating approach was found to be thorough, complete, and structured to provide an estimate with a high degree of confidence.

The Tank Waste Retrieval and Disposal Updated Baseline has received third party review and revision by the RTP integrated planning teams, senior management within LMHC, and by the PHMC Team. The focus of the these optimization reviews was to identify duplicate or missing activities, evaluate activities for soundness, logic flow and appropriate schedule float. In addition the logic was crosswalked to the WBS to assure all scope was included, and to analyze transfer of work tasks from Operations WBS elements to Retrieval and Disposal WBS elements. 


\subsection{FINANCIAL RISK ANALYSIS APPROACH - PHASE 1B}

This section includes a discussion of the quantification and qualification process using the TBR risk assessment format and a description of the data modeling approach using the @Risk software.

\subsubsection{Technical Basis Review Risk Assessment Process}

The TBR package as previously discussed is the summarization of RTP task package work scope activities that capture specific technical scope. A network of interrelated logics sequence the tasks and dictate schedule durations as well as cost for resources and materials. For each TBR package, the Risk Assessment Model (Figure 6) was the process to be used to prepare a TBR risk assessment form (Example shown in Appendix A). The TBR sample population utilized to ascertain the execution risk of the Phase 1B Baseline included over 200 of the one-ofa-kind and first-of-a-multiple activities from a total activity population of over 600 at the Level 7 of the WBS (equivalent to Level 1 Logics). The TBR Risk assessment for the one-of-a-kind activities was decomposed to Level 8 of the WBS (Level 2 Logic) to assess discrete technical risk. The TBR Risk assessment is a systematic, controlled method of describing and quantifying the risk associated with a particular activity, determining a mitigation plan, identifying any remaining residual risk that is certain to occur, and then determining a probability of the residual risk occurring. Activity owners further summarized the TBR assumption(s), documented the assumption basis as well as the resulting baseline risk and again determined the probability of the assumption(s)/risk(s) occurring. Finally, the activity owners assigned the overall TBR confidence of performing the scope.

The recommended plan to proceed must consider the cost, schedule, and technical allowances that are proposed to deal with risk events. The detailed task package risks are categorized as described in Section 2.2.2 and the Retrieval and Disposal Mission and Tank Waste Remediation System are considered for the total network of activities that must be performed to meet the mission requirements. The financial analysis risk assessment quantifies the achievability of the mission at the target budget and schedule, and focuses on the bandwidth of increasing the certainty of achieving the mission by compensating for the risk events.

The risk assessment is consolidated at two different schedule logic levels. First, it is performed on the Level 2 Logic activities and then is summarized to the Level 1 Logic package. This first consolidation captures the lowest level of planning in a logical sequence, summarized to an element of the Level 1 Logic, and the risk items are evaluated in a controlled, understandable fashion. Second, integrated program risks are considered for Level 0 Logic activities that are significant or crosscut through Retrieval and Disposal Mission and the balance of the TWRS Project. This is accomplished by using the TBR risk assessment basis to build up the ground work for assessing integrated program risks. This second level of risk assessment ensures that the base level of detailed work is understood. This two-level focus also assures that 
Figure 6. Risk Assessment Model.
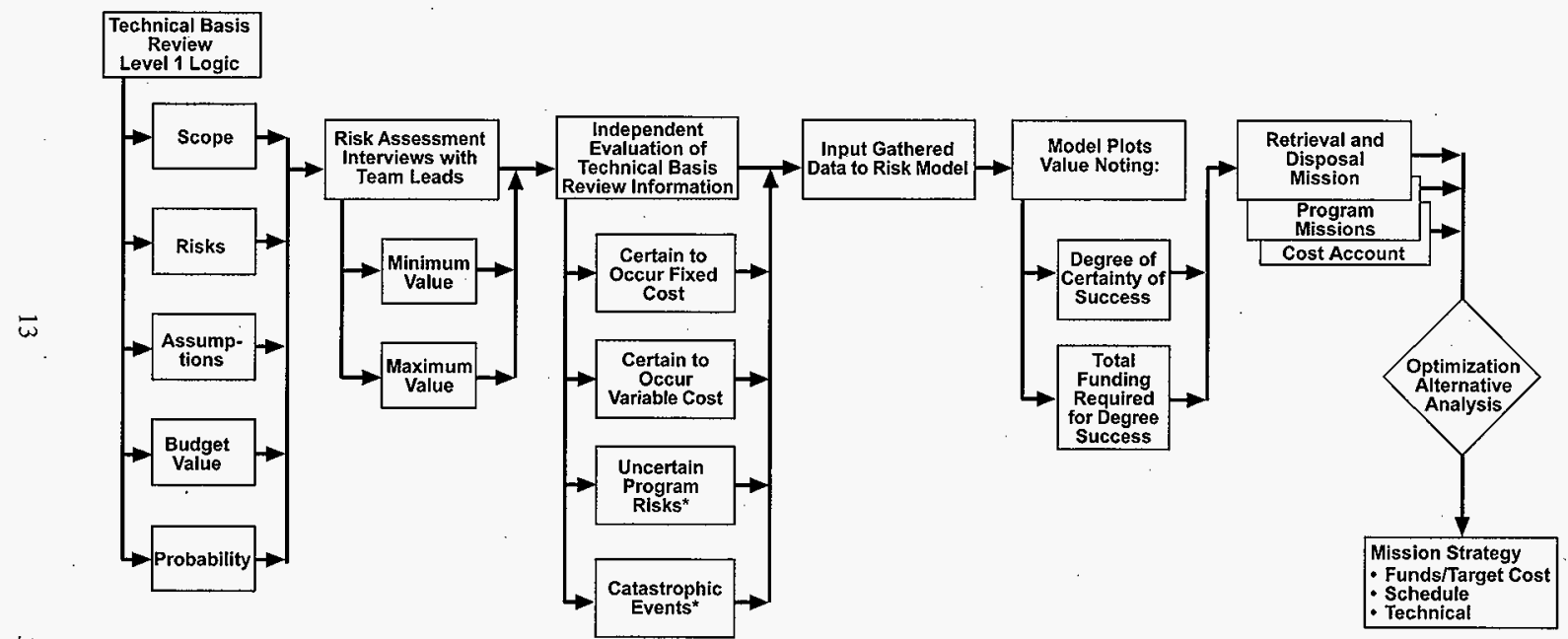
all known risk considerations are evaluated as part of a sound business approach to meet the desired end points of the RTP.

The risk assessment considers the inherent variabilities and risks that are embodied in the TBR detailed work packages activities and quantifies the risk in specific terms, outlines the current mitigation plan, establishes a bandwidth of factors for the risk, and assigns the probability of the risk occurring. Each TBR package is assigned, by the activity owner, the probability of accomplishing all of the work activities. This probability establishes the basis for the risk modeling activity.

\subsubsection{Data Modeling - @Risk}

Data modeling produces a view of the entire spectrum of cost or schedule outcomes, quantifying the likelihood of successfully completing the program or project within a given funding level or time frame. This analysis integrates input in a structured risk assessment process from: requirements definition, methods of accomplishment, cost estimates, expert judgement/experience, and commercial/government data.

This type of analysis has been employed in a wide variety of applications, such as: environmental restoration projects, waste management projects, surveillance/maintenance operations, facility/process operations, capital project prioritization, software package implementation, workload forecasting, and contract liability.

In addition to providing an independent perspective on financial risk, the process has proven invaluable as a tool to improve understanding and management of cost and schedule risks and has become an essential part of the conduct of business wherever it has been implemented.

The analysis process uses a Monte Carlo statistically-based risk evaluation technique for assessing cost/schedule impacts due to technical/programmatic/management uncertainties and . other variables. The process is based on the concepts that the impact of any risk can be translated into terms of cost and that any cost element can be characterized as one of four basic types:

Category 1. Project Specific - Fixed -- event which is certain to occur or item which is certain to be required and cost or quality is firmly known.

Category 2. Project Specific - Variable -- event which is certain to occur or item which is certain to be required and whose cost or quantity varies over some finite range.

Category 3. Integrated Program -- event that could happen or item that could be required but may not occur or be required at all; if such an event occurs, then a cost or schedule impact which varies over some finite range results. 
Category 4. Technical Issues for Programmatic Risk -- event driven by a technical issue which has a very small probability of occurrence; if such an event occurs, then a significant cost or schedule impact results.

The model is populated with the TBR risk assessment data points of budget cost, minimum expected cost, maximum expected cost, and the confidence of performing the TBR scope. An example of the detailed TBR risk assessments, outlining summary risks and minimum, maximum and nominal budget values is found in Appendix A. The TBR risk assessment modeling uses triangular distribution to calculate and project the likelihood of performing the composite TBR at the budgeted value. The modeling software used is @Risk, a commercially available risk analysis and simulation software system for analysis of business and technical situations impacted by risk. An example of the results of the modeling and the calculated probability distribution in dollars is found in Appendix A. In summary, the financial analysis risk assessment provides the preview of the RTP likelihood of success and the allowances required to improve the certainty of success. 
HNF-2017 Rev 0

This page intentionally left blank. 


\subsection{UPDATED BASELINE}

This section outlines the major assumptions in the development of the Phase 1B decomposed logics, describes the baseline from the current MYWP basis, and graphically portrays the output of the detailed resource loaded schedules segregated by Project Baseline Summary (PBS).

\subsection{ENABLING ASSUMPTIONS}

Several enabling assumptions were utilized in the development of the Phase $1 \mathrm{~B}$ logics as detailed in HNF-1942 (Baldwin et al. 1998). The focus of the Phase 1B Retrieval and Disposal Mission begins with the current MYWP of $\$ 1857$ million as shown in Table 1. The total TWRS project MYWP of \$4954 million includes the costs for: (1) the Retrieval and Disposal Mission of $\$ 1857$ million, (2) Base Operations including Characterization and Safety Issue Resolution projects, (3) support to Phase 2 private contractor operations, and (4) Tank Farm Closure. The Regulatory Unit and Phase 1B operations of the private contractors facilities costs are excluded from both figures.

Interfaces with the Waste Management Facilities have been coordinated and integrated with the Waste Management Project. The costs for these facilities are not included herein but are funded and supported through the Waste Management Project as follows: (1) the 222-S Laboratory base operations costs support to tank characterization is supported through Phase $1 \mathrm{~B}$, (2) the 242-A Evaporator required to support AY/AZ Farm sludge washing dilute wastes is supported through Phase 1B, (3) the Effluent Treatment Facility which is required to support treatment of the 242-A Evaporator condensate is supported through Phase 1B, (4) the Liquid Effluent Retention Facility which is required for treatment of radioactive or dangerous liquid effluents generated by the private contractors is supported through Phase 1B, and (5) the Treated Effluent Disposal Facility is required to provide treatment of non-radioactive, non-dangerous liquid effluents generated by private contractors is supported through Phase $1 \mathrm{~B}$.

\subsection{BASELINE DESCRIPTION}

The current MYWP baseline for the Retrieval and Disposal Mission as it resides in Primavera is $\$ 1,275$ million as shown in Table 2 . This was adjusted by adding the $\$ 39$ million Retrieval and Disposal reserve. The sum of $\$ 1,314$ million forms the basis in the MYWP from which adjustments were made.

Section 4.1.1, "Phase 1B Scope Not in Logics," includes $\$ 543$ million of Phase 1B level of effort activities contained in the multi-year work plan that were not included in the decomposed logics as specific activities, and therefore are not in the RTP schedule baseline 
(i.e., Waste Integration Team/Management Systems, and Retrieval Project Management/ Administration).

Section 4.1.2, "Updated Phase 1B Baseline to Meet the Critical Path," represents activities planned in the resource-loaded schedule baseline tied to the decomposed logics. Values include escalation through FY 2006 and are in constant FY 2006 dollars thereafter. This results in an increase of $\$ 159$ million to $\$ 2,016$ million.

Table 2 summarizes these costs, and included in Appendix A is the TWRS Baseline Analysis Summary detailed by year.

Table 2. Update Phase 1B Baseline.

\begin{tabular}{|l|r|}
\hline \multicolumn{1}{|c|}{ Section } & $\begin{array}{r}\text { Retrieval and disposal } \\
\text { (millions) }\end{array}$ \\
\hline Current MYWP Primavera Baseline & $\$ 1275$ \\
Retrieval \& Disposal Reserve & -39 \\
Baseline in MYWP & $\$ 1314$ \\
Phase 1B Scope Not in Logics (Section 4.1.1) & 543 \\
Budget Requirements (MYWP) & \\
Updated Baseline to Meet Critical Path (Section 4.1.2) & \\
Updated Phase 1B Baseline & 159 \\
\hline $\begin{array}{l}\text { HLW }=\text { high-level waste. } \\
\text { LAW }=\text { low-activity waste. } \\
\text { MYWP }=\text { multi-year work plan. }\end{array}$ & $\$ 2016$ \\
\hline
\end{tabular}

\subsection{TIME PHASED COST BY PROJECT BASELINE SUMMARY}

The cost summary included herein is a time phased presentation of the updated Phase $1 \mathrm{~B}$ logic baseline of $\$ 2,016$ million as shown in Table 2 . Cost breakouts are by PBS.

Figure 7 displays the Phase $1 \mathrm{~B}$ budgets on a cumulative basis. The figure depicts the impacts of near-term tank retrieval system installations. Infrastructure construction is conducted in FY 2000 to FY 2002. Infrastructure costs in FY 2003 to FY 2011 are driven by electrical utilities furnished to the private contractors and the processing of liquid effluent. The process waste support costs are attributable to requirements for the Waste Integration Team and the transfer of the Management Support Project to the Retrieval Project commencing in FY 2006. The significant expenditures for Immobilized Waste in FY 2000 to FY 2004 are the construction of the immobilized low-activity waste (ILAW) disposal and immobilized high-level waste (IHLW) storage facilities. 
S.OONヨ S30ก7ONI OHW7.

\begin{tabular}{|c|c|c|c|c|c|c|c|c|c|c|c|c|c|c|}
\hline $006^{\prime} S 10^{\prime} 2$ & $198^{\circ}+16^{\prime} 1$ & $b 80^{\prime} 06 L^{\prime} !$ & $t 16^{\prime} 999^{\prime} 1$ & $669^{\prime} \angle \varepsilon G^{\prime} \mid$ & $96 L^{\prime} 600^{\prime \prime}$ & $\varepsilon 18^{\prime} 69 z^{\prime} \downarrow$ & $0 \varepsilon \varepsilon^{\prime} \varepsilon \mapsto l^{\prime} l$ & 0201006 & $00 L^{\prime} Z 0 L$ & LZE' $9 \varepsilon S$ & $\varepsilon 98^{\prime} 888$ & $958^{\prime} 6 \varepsilon z$ & $66 \varepsilon^{\prime \prime}+0 \downarrow$ & T $\forall \perp 01$ \\
\hline $269^{\prime} 800^{\circ} \mathrm{L}$ & $90 \varepsilon^{\prime} \angle 96$ & pL9'816 & $19 \varepsilon^{\top} L 28$ & $909^{\prime} 128$ & $\overline{8 \varepsilon 60 L L}$ & $\overline{Z g Z^{\prime}+L}$ & $\overline{\text { S6L'St59 }}$ & DEL'Z8म & $\overline{9 Z 8^{\prime} 0 \angle \varepsilon}$ & $\overline{Z l F L 6 Z}$ & $\overline{092602}$ & $\overline{\text { OSL'GZL }}$ & $867^{\prime} 09$ & \\
\hline S66'เป & $00 \varepsilon^{\prime} 80 \varepsilon$ & $898^{\prime} \varepsilon 0 \varepsilon$ & $\varepsilon \angle 6^{\prime} 66 z$ & $999^{\prime} 962$ & $\angle 0 \varepsilon^{\prime} \varepsilon 6 Z$ & $98 L^{\prime}<82$ & $86 \angle ' g L Z$ & $1 \angle t^{\prime} Z s z$ & $0 Z L^{\prime} 80 Z$ & $210 ' 891$ & $09 L^{\prime} 6 Z L$ & $661 ' 82$ & $s z^{\prime} L z$ & \\
\hline $6 L L^{\prime} l$ & $6 \angle L^{\prime}$ & $6 L L^{\prime} L$ & $6 L L^{\prime} !$ & $6 \angle L^{\prime} L$ & $9 L L^{\prime} L$ & DSL't & $20 L^{\circ} b$ & Ess'! & $8 \mathrm{bs}^{\prime} \mathrm{L}$ & $60 S^{\prime} \mathrm{L}$ & $08 \nabla^{\circ}$ & $6 \varepsilon \varepsilon^{\prime} b$ & SQL & \\
\hline $8+9^{\prime} \angle 0 b$ & $z 8 S^{\prime} \mathrm{\varepsilon OL}$ & $\varepsilon 86^{\prime} \angle 6$ & $S t S^{\prime}+6$ & $16 l^{\prime}+8$ & $990 ' 91$ & $96 z^{\prime} 99$ & $\varepsilon \angle t^{\prime} 8 S$ & $89 t^{\prime} 0 \mathrm{~g}$ & $86 \varepsilon^{\prime} \varepsilon b$ & $z 9 b^{\prime} \varepsilon z$ & $\downarrow \nabla \varepsilon^{\prime} z !$ & $\varepsilon \angle 6^{\prime} G$ & $86 s^{\prime} t$ & \\
\hline$I Z B^{\prime} \varepsilon \not Z$ & $9 b z^{\prime} 2 z z$ & $\$ 81 ' z 0 z$ & 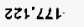 & $\angle \nabla S^{\prime} L S i$ & $09 p^{\prime} s z 1$ & $950^{\circ} 66$ & $t+\theta^{\prime} \varepsilon 2$ & $899^{\circ} \angle b$ & $89 \varepsilon^{\circ} \varepsilon z$ & $+9 t^{\prime} 6$ & $86 L^{\circ} 8$ & $\log 9$ & $996^{\circ}$ & SaW \\
\hline$z L L S$ & $z L L^{\prime} s$ & ZLL'S & ILL'S & LLL'S & OLL'S & $O L L^{\prime} \mathrm{S}$ & $\varepsilon 9 L^{\prime} \mathrm{g}$ & $9 \varepsilon \varepsilon^{\prime} \varsigma$ & $0 \angle 0^{\circ} S$ & $Z \angle I ' b$ & $9 \tau t^{\prime} \varepsilon$ & $\triangleright 98^{\prime} z$ & $1<\varepsilon^{*} \mid$ & \\
\hline $8 \nabla Z^{\prime} \downarrow \triangleright \varepsilon$ & $9 \varepsilon 8^{\circ} 00 \varepsilon$ & $+\angle L ' B g Z$ & $\varepsilon 9 \varepsilon^{\prime} \& 1 z$ & $0+1 ' 9<1$ & $688^{\prime} \mathrm{S} \&$ & $005^{\prime} \mathrm{s} 6$ & $0 s L^{\prime} Z 8$ & $008^{\prime} 99$ & $008^{2} 60$ & $008^{\prime} z \varepsilon$ & $000^{\circ} \triangleright 2$ & ooz's b & $008^{\circ} 2$ & $\mathrm{~T}^{1} \mathrm{~N}$ \\
\hline
\end{tabular}

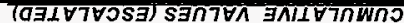

\begin{tabular}{|c|c|c|c|c|c|c|c|c|c|c|c|}
\hline IL 서 & $\overline{0 \mathrm{OLA}}$ & $\overline{60 \lambda=}$ & $\overline{80 \lambda}$ & $\overline{20 \lambda=}$ & $\overline{90 \lambda \bar{A}}$ & $\overline{90 K}$ & $\overline{70 \lambda=}$ & $\overline{80 \lambda A}$ & 201 & $\overline{0 \lambda}$ & 861 \\
\hline
\end{tabular}

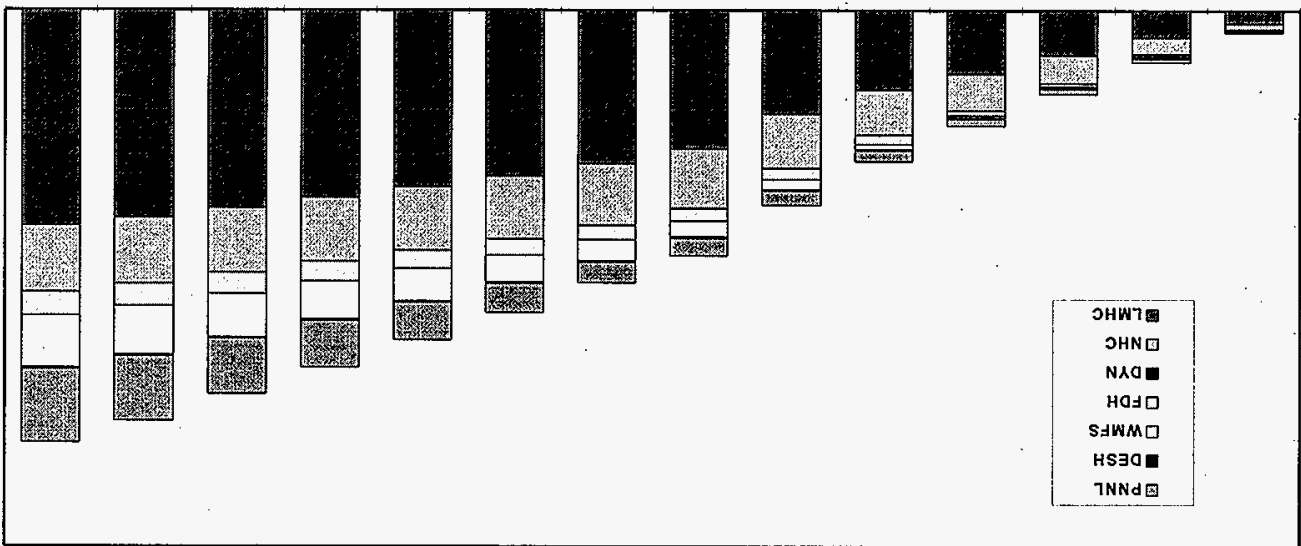

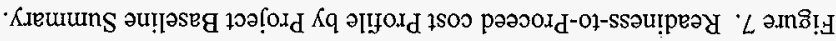


HNF-2017 Rev 0

This page intentionally left blank. 
HNF-2017 Rev 0

\subsection{ANALYSIS}

This section presents the analysis which includes changes to the MYWP baseline, the project specific and integrated program risk analysis, critical path schedule analysis, FY 1998 and FY 1999 target funding analysis, staffing analysis, and cost reduction opportunities.

\subsection{BASELINE CHANGES}

This is a summary level discussion of the scope, schedule, and cost changes from the FY 1998 MYWP baseline to the Phase 1B baseline. Table 3 presents a walkdown of these changes and sections where discussed.

Table 3. Baseline Changes. (Dollars in millions)

\begin{tabular}{|l|r|}
\hline Baseline in MYWP & $\$ 1314$ \\
\hline Phase 1B Scope Not in Logics (Section 4.1.1) & 543 \\
Updated Baseline to meet Critical Path (Section 4.1.2) & 159 \\
Other TWRS Phase IB Support (Section 4.1.3) & 117 \\
Retrieval Scope Transfer Shortfall (Section 4.1.4) & 46 \\
\hline Phase 1B Baseline (requirements @ 50\% certainty) & $\$ 2179$ \\
\hline \multicolumn{2}{|c|}{ MYWP = multi-year work plan. } \\
TWRS = Tank Waste Remediation System.
\end{tabular}

\subsubsection{Phase 1B Scope Not in Logics}

The TWRS Program Logics were developed to include only the discrete Phase 1B scope not in logics activities required to meet specified deliverables. The activities are contained in the MYWP baseline but were not reestimated as part of the Phase 1B logics. Table 4 lists these efforts and associated values. Appendix A provides detailed costs by year.

Table 4. Phase 1B Scope Not in Logic. (Dollars in millions)

\begin{tabular}{|l|r|}
\hline Project Management/Administration & $\$ 73$ \\
Feed Process Systems Definition & 7 \\
Retrieval Systems Definition & 17 \\
Retrieval Operations & 69 \\
Future DST Retrieval Operations & 6 \\
Retrieval Operations/Characterization & 1 \\
WIT/Management Systems & 284 \\
Escalation & 86 \\
\multicolumn{1}{|c|}{ Total } & $\$ 543$ \\
\hline \multicolumn{1}{|c|}{ DST $=$ double-shell tank. } & \\
WIT = Waste Integration Team. &
\end{tabular}




\subsubsection{Updated Baseline to Meet Critical Path}

As shown in Table 2, the updated baseline to meet the critical path is $\$ 159$ million above the budget requirements. Table 5 outlines the increase by major focus area.

Table 5. Updated Baseline to Meet Critical Path. (Dollars in millions)

\begin{tabular}{|l|r|}
\hline New Phase 1B Logic Estimates & $\$ 84$ \\
Original Unfunded Utilities & 85 \\
Original Unfunded Private Contractor Training & 29 \\
Retrieval \& Disposal Reserve & $(39)$ \\
\multicolumn{1}{|c|}{ Total } & $\$ 159$ \\
\hline
\end{tabular}

From a project perspective, the new Phase 1B estimates increased $\$ 84$ million which were primarily driven by the two feed batches to meet the maximum order quantity. Infrastructure increased $\$ 114$ million driven by the previously identified shortfalls in the MYWP for utilities of $\$ 85$ million for the private contractor in FY 2003/2004 and training of private contractor operators for $\$ 29$ million in FY 2001/2002. Retrieval and disposal reserves of $\$ 39$ Million were removed from the MYWP estimates. Appendix A provides detailed costs by year.

Cumulative and annual graphs of costs are shown in Figures 8 and 9. Analysis of the annual difference denotes acceleration of expenditures in the Phase $1 \mathrm{~B}$ planning document. The acceleration results from the scheduling of scope to meet the Phase $1 \mathrm{~B}$ mission requirements. Specifically, a significant construction period extends through FY 2006 which installs multiple retrieval systems in support of waste staging for the private contractors including extensive activities beginning in FY 2002 and extending through FY 2004 in support of waste retrieval systems for tanks SY-101, AN-107, AN-102, and AN-106. Additional Infrastructure unfunded utilities and training further drive the FY 2000 through 2004 cost increases.

\subsubsection{Other TWRS Phase 1B Support}

The other TWRS Phase 1B Support Scope section represents the Retrieval and Disposal share of the Management Support System Project based on a business volume allocation totaling $\$ 117$ Million. These activities are listed in Table 6 and are contained in the MYWP baseline but were not reestimated as part of the Phase $1 \mathrm{~B}$ logics. Appendix A provides detailed costs by year. 
Figure 8. Phase 1B to Multi-Year Work Plan Baseline cumulative cost Comparison.

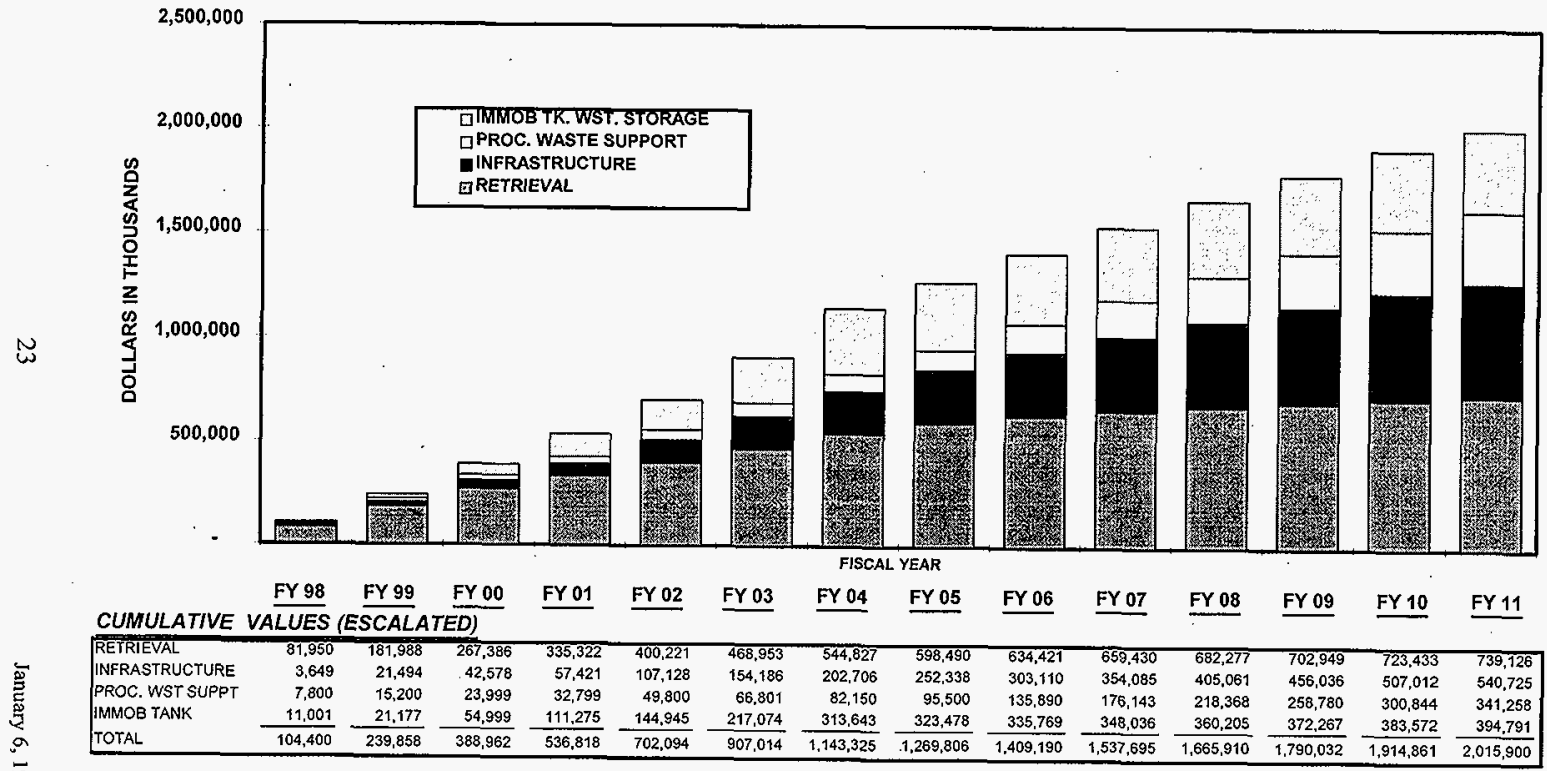


Figure 9. Phase 1B to Multi-Year Work Plan Baseline Cost Comparison.

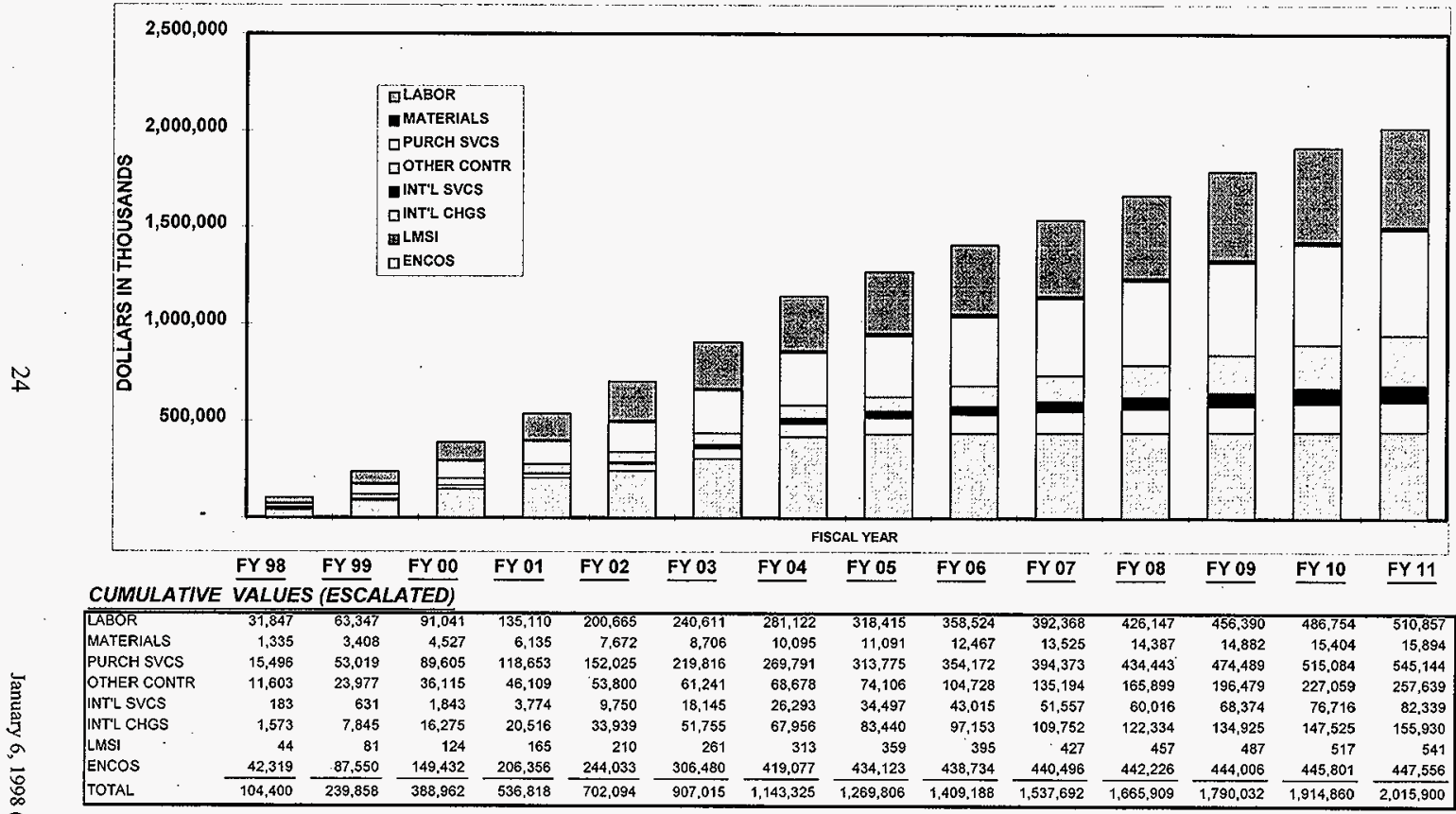


Table 6. Other Tank Waste Remediation System Phase 1B Support Scope.

(Dollars in millions)

\begin{tabular}{|l|r|}
\hline ESH/QA Business Volume & $\$ 6$ \\
Performance Fee & 75 \\
Characterization Support & 4 \\
Central Instrument Control Facility & 2 \\
Cross Site Transfer Line & 3 \\
Management Support Program Planning & 22 \\
Management Support Systems Engineering & 5 \\
\multicolumn{1}{|c|}{ Total } & $\$ 117$ \\
\hline
\end{tabular}

ESH/QA = Environmental, Safety, Health, and Quality Assurance.

\subsubsection{Retrieval Scope Transfer Shortfall}

The Retrieval Scope Transfer Shortfall Section outlines an additional $\$ 46$ million required to execute the TWRS baseline driven by transition of Operations, Characterization, and the Safety Authorization Basis scope to the Retrieval and Disposal WBS.

The cost increase is partially offset by the deletion of the Liquid Effluent Processing costs already included in the Waste Management project baseline. These anomalies were identified during the detailed Phase 1B analysis and with the exception of the Liquid Effluent Processing costs, existed when the MYWP was submitted. These estimates are considered preliminary and may be reduced upon further analysis. The primary drivers for the additional system shortfall are noted in Table 7. Appendix A provides detailed costs by year.

Table 7. Retrieval Scope Transfer Shortfall. (Dollars in millions)

\begin{tabular}{|l|r|}
\hline SST Sustaining Operations (Section 4.1.4.1) & $\$ 14$ \\
Characterization Base Load Support (Section 4.1.4.2) & $(13)$ \\
DST Baseline Omission (Section 4.1.4.3) & 146 \\
Characterization Sustaining Operations (Section 4.1.4.4) & 7 \\
Safety Authorization Basis Sustaining Operations (Section 4.1.4.5) & 47 \\
Liquid Effluent Processing (Section 4.1.4.6) & $(155)$ \\
$\quad$ Total & $\$ 46$ \\
\hline DST = double-shell tank. & \\
SST = single-shell tank. &
\end{tabular}

4.1.4.1 Single-Shell Tank Sustaining Operations. Based on the planning assumptions, the Retrieval and Disposal Mission WBS assumes the responsibility for ensuring safe minimum operations of the single-shell tank (SST) farms, commencing in FY 2002. To meet this requirement, the MYWP baseline contains scope within WBS element 1.1.3.1.01.09, Phase 1 Retrieval Operations, to maintain, monitor, and operate the SST farms including ancillary equipment after interim stabilization is achieved. This scope was estimated at approximately $\$ 7.0$ million per year. Revised estimates from Operations indicate the required cost to sustain 
SST operations is $\$ 12.0$ million per year. This has resulted in a $\$ 5.0$ million per year shortfall starting in FY 2005 as noted in Table 8.

Table 8. Single-Shell Tank Sustaining Operations Costs (TW03).

\begin{tabular}{|r|r|r|r|r|}
\hline \multicolumn{5}{|c|}{ Dollars in millions } \\
\hline $\begin{array}{c}\text { FY 2002 } \\
\text { unescalated }\end{array}$ & $\begin{array}{c}\text { FY 2003 } \\
\text { unescalated }\end{array}$ & $\begin{array}{c}\text { FY 2004 } \\
\text { unescalated }\end{array}$ & $\begin{array}{c}\text { FY 2005 - FY 2011 } \\
\text { unescalated }\end{array}$ & Total \\
\hline$\$(7.0)$ & $\$(7.0)$ & $\$(7.0)$ & $\$ 5.0$ per year & $\$ 14.0$ \\
\hline
\end{tabular}

Cost credits in FY 2002 - FY 2004 are driven by Operations continuing to manage SSTs through FY 2004 due to salt well pumping moratorium per the MYWP while Retrieval had planned the handoff in FY 2002 per original baseline assumption. The duplication was eliminated resulting in a net increase of $\$ 14$ million.

4.1.4.2 Characterization Base Load Support . This credit entry of $\$ 13$ Million represents the difference between the total Retrieval Data Quality Objective sampling requirements estimated in the Phase $1 \mathrm{~B}$ resource loaded schedules compared to what support can be funded by the base Characterization project. The baseline duplication was eliminated as shown in Appendix A.

4.1.4.3 DST Baseline Omission. Based on the planning assumptions, the Retrieval and Disposal Mission WBS assumes the responsibility for ensuring safe minimum operations of the double-shell tank (DST) farms, commencing in FY 2006. To meet this requirements, the MYWP baseline contains scope within WBS element 1.1.3.1.01.09, Phase 1 Retrieval Operations, to maintain, monitor, and operate the DST farms and related facilities and perform regulator compliance actions.

The shortfalls in FY 2001 - 2005 are due to DST activity omissions in the initial MYWP. The DST operations were understated by those values. Estimates by Operations to sustain base operations is $\$ 40$ million per year, resulting in a $\$ 10$ million per year shortfall commencing in FY 2006. These adjustments result in a $\$ 146$ million increase as noted in Table 9.

Table 9. Double-Shell Tank Baseline Omissions (TW03).

\begin{tabular}{|r|r|r|r|r|r|r|}
\hline \multicolumn{7}{|c|}{ Dollars in millions } \\
\hline $\begin{array}{r}\text { FY 2001 } \\
\text { unescalated }\end{array}$ & $\begin{array}{c}\text { FY 2002 } \\
\text { unescalated }\end{array}$ & $\begin{array}{c}\text { FY 2003 } \\
\text { unescalated }\end{array}$ & $\begin{array}{c}\text { FY 2004 } \\
\text { unescalated }\end{array}$ & $\begin{array}{c}\text { FY 2005 } \\
\text { unescalated }\end{array}$ & $\begin{array}{c}\text { FY 2006 - } \\
\text { FY 2011 } \\
\text { unescalated }\end{array}$ & Total \\
\hline$\$ 17.6$ & $\$ 17.1$ & $\$ 17.0$ & $\$ 16.9$ & $\$ 16.9$ & $\$ 10.0$ per year & $\$ 145.5$ \\
\hline
\end{tabular}


4.1.4.4 Characterization Sustaining Operations. The Retrieval Project assumed responsibility for tank sampling and analysis from FY 2003 through FY 2011. To meet this requirement, the MYWP baseline contains scope within WBS element 1.1.3.1.01.09, Phase 1 Retrieval Operations to provide sustaining Characterization Operations for feed delivery and disposal process tests starting in FY 2003 amounting to $\$ 7.0$ million to $\$ 7.3$ million per year.

The anomaly is related to the fact that the Characterization Project currently ends in FY 2001 per a recently approved Hanford Federal Facility Agreement and Consent Order (Tri-Party Agreement) (Ecology et 1. 1996) change request while Retrieval assumed takeover in FY 2003' per the original assumption, resulting in a $\$ 7.2$ million sustaining operations shortfall in FY 2002 as shown in Appendix A.

4.1.4.5 Safety Authorization Basis. Based on the planning guidance, the Waste Retrieval Project has responsibility for conducting safety studies to support the installation of mixer pumps in AP-102, AP-104, and AN-105 as well as all tanks identified for Phase 1B feed. To meet this requirement, the Waste Retrieval MYWP baseline contains scope/funding within WBS element 1.1.3.1.01.02, Feed Process Systems Definition, to update/maintain the Authorization Basis for waste feed delivery.

Guidance did not direct the Retrieval and Disposal Mission to include safety project scope/funding. It was assumed that the waste feed delivery Authorization Basis being developed in FY 1998 and FY 1999 would provide the safety basis for waste feed delivery during Phase 1B operations and extensive unreviewed safety question (USQ) evaluations would not be required after the Authorization Basis has been developed. Upon further analysis, this assumption was not correct. The estimate to maintain the Authorization Basis current is $\$ 5.1$ million per year resulting in a \$4.8 million annual shortfall in FY 2006 through FY 2011. The total adjustment is $\$ 47$ million and is shown time phased in Appendix A.

4.1.4.6 Liquid Effluent Processing. The detailed Phase 1B planning estimates included costs to process the liquid waste that is planned to be generated through the operation of the private contractors vitrification facilities. Subsequent analysis has determined that adequate scope and funding has already been included in the Waste Management Project. This credit entry of $\$ 155$ million as shown in Appendix A eliminates the duplication of planning for the effort.

\subsection{RISK ANALYSIS - PHASE 1B - PROJECT SPECIFIC}

Included herein are the results of the modeling of project specific fixed (category I) and variable (category II) risks as defined in Section 2.2.2. Table 10 takes the Updated Phase 1B Baseline and walks it down to the Phase 1B logic base or TBR scope and compares it to the input data used as the cost basis for modeling risk. The minor differences were caused by updates to the final baseline product after completion of the analysis and do not effect the outcome. 
Table 10. Updated Baseline Input to Risk Model.

\begin{tabular}{|c|c|c|}
\hline $\begin{array}{l}\text { Updated Phase 1B Baseline } \\
\text { Phase 1B Scope not in Logics } \\
\text { Phase 1B Logics (escalated) } \\
\text { Escalation }\end{array}$ & $\begin{array}{r}\$ 2016 \\
(543) \\
\$ 1473 \\
(179)\end{array}$ & $\begin{array}{l}\text { Cost Basis for } \\
\text { Modeling Risk }\end{array}$ \\
\hline Phase 1B Logics (TBR Scope) & $\$ 1294$ & $\$ 1261$ \\
\hline $\begin{array}{r}\text { HLW Feed Delivery } \\
\text { LAW Feed Delivery } \\
\text { Infrastructure } \\
\text { Immobilized Waste }\end{array}$ & $\begin{array}{l}492 \\
456 \\
346\end{array}$ & $\begin{array}{r}60 \\
375 \\
469 \\
357\end{array}$ \\
\hline
\end{tabular}

HLW = high-level waste.

LAW $=$ low-activity waste.

A Monte Carlo simulation was performed on inputs to the cost estimate and expressed as ranges of possible values. HLW Feed Delivery and LAW Feed Delivery (Section 4.2.2), Infrastructure (Section 4.2.3), and Immobilized Waste (Section 4.2.4) are treated separately in the analysis.

In aggregate, the analysis as shown in Figure 10 suggests a program certainty of $50 \%$ for project specific risk. The recommended program certainty is $80 \%$ to provide a conservative estimate of costs to achieve each TBR goal. This would require an increase of $\$ 24.5$ million when evaluated by each program area and summed as shown in Table 11.

Care and reason should be used in interpreting each curve and comparing it to the total cost curve, which is basically the summation of the four categories of costs mentioned above. Specifically, the $80 \%$ confidence interval on the "total" cost curve cannot be compared directly to the summation of the $80 \%$ confidence intervals from the four category curves. This is because one or more of the cost areas (HLW, LAW, Infrastructure, and Immobilized Waste) is more dominant in determining the total cost of the project. Thus, the variation in the HLW curve may prove to have little impact on the summary curve, which might be driven by the variation and absolute values associated with the more dominant (and more uncertain) Immobilized Waste cost curve. Thus, it is not uncommon for the sum of several cost categories at a given confidence interval NOT to equal the summary curve at the same confidence interval.

The relatively small spread suggests the program is well understood, there are no new technologies or breakthroughs required or planned, and the estimates of resources required to perform each task are fairly precise. 
HNF-2017 Rev 0

Figure 10. Total Phase 1B Cost (Cat. 1/11).

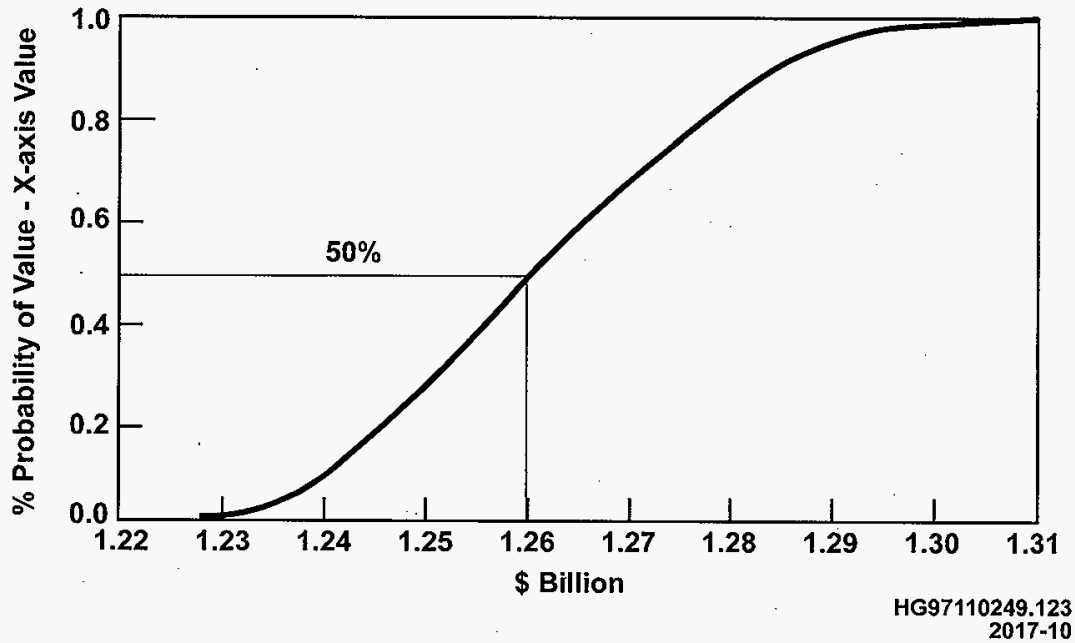

Table 11. Program Certainties.

RTP Level 1 Logic - technical basis review packages and technical basis review risk assessment form

\begin{tabular}{|c|c|c|c|c|c|c|}
\hline Item & $\begin{array}{c}\text { Probability } \\
\%\end{array}$ & $\begin{array}{c}\text { @Risk } \\
\text { budget \$M }\end{array}$ & $\begin{array}{c}\text { Probability } \\
\%\end{array}$ & $\begin{array}{c}\$ M \\
\text { @ } 80 \%\end{array}$ & Change & $\begin{array}{c}\% \\
\text { Change }\end{array}$ \\
\hline $\begin{array}{l}\text { HLW Feed Delivery } \\
\text { (Section 4.2.1) }\end{array}$ & 40 & 60.0 & 80 & $6 \mathrm{I} .5$ & 1.5 & 2.5 \\
\hline $\begin{array}{l}\text { LAW Feed Delivery } \\
\text { (Section } 4.2 .2 \text { ) }\end{array}$ & 35 & 375.0 & 80 & 379.0 & 4.0 & 1.1 \\
\hline $\begin{array}{l}\text { Infrastructure } \\
\text { (Section 4.2.3) }\end{array}$ & 55 & 469.0 & 80 & 477.0 & 8.0 & 1.7 \\
\hline $\begin{array}{l}\text { Immobilized Waste } \\
\text { (Section 4.2.4) }\end{array}$ & 40 & 357.0 & 80 & 368.0 & 11.0 & 3.1 \\
\hline Total above & 50 & 1261.0 & 80 & 1285.5 & $\$ 24.5$ & 1.9 \\
\hline (a) Risk Curve, Figure 10 & 50 & 1261.0 & 80 & 1277.0 & 15.0 & 1.2 \\
\hline
\end{tabular}

HLW $=$ high-level waste.

$\mathrm{LAW}=$ low-activity waste 
Examples of specific drivers are discussed in subsequent sections. As previously stated individual TBR Risk Assessments have been prepared and are available which detail the specific risks, ranges, and confidence levels. These have been compiled into the TWRS Retrieval and Disposed Mission Risk List and will be managed according to HNF-SD-WM-PMP-018, Tank Waste Remediation System Risk Management Plan (Zimmerman 1998b) and represented in the Management Assessment of TWRS contractor RTP with Phase 1B privatization (HNF-2021) (Payne et al. 1998).

The time-phasing of the project specific risk allocations shown in Table 12 was made based on known risks associated with construction of the HLW Storage facilities, potential additional requirements for Characterization Laboratory methods for complex HLW analysis and the potential that the Nuclear Regulatory Commission could rule that ILAW could not be disposed on site. Also included is the potential for increased infrastructure costs due to construction delays and the variability of electrical and waste disposal rates.

Table 12. Time Phasing of Project Specific Risk Allocations.

\begin{tabular}{|c|c|c|c|c|c|c|}
\hline \multicolumn{7}{|c|}{ Dollars in millions } \\
\hline FY 1998 & FY 1999 & FY 2000 & FY 2001 & FY 2002 & $\begin{array}{c}\text { FY 2003- } \\
2011\end{array}$ & Total \\
\hline \$-- & \$- & $\$-$ & $\$-$ & $\$ 17.5$ & $\$ 7.0$ & $\$ 24.5$ \\
\hline
\end{tabular}

Additional risk analyses will be performed to quantify and adjust the risk on an annual basis.

\subsubsection{High-Level Waste Feed Delivery Risk Analysis}

The major cost risks and drivers are as follows:

- An in-tank waste mixer or retrieval pump failure (W-320 and AZ-101 installations, W-211 retrieval systems) impacting feed delivery

- Additional requirements for characterization laboratory methods for complex HLW analysis.

The risk analysis modeling shown in Figure 11 suggests a $40 \%$ program certainty at the updated baseline cost of $\$ 60$ million. At the recommended program certainty of $80 \%$, a $\$ 1.5$ million increase to a total of $\$ 61.5$ million is required to compensate for the specific major cost risks and drivers and other activities for the overall HLW program. 
Figure 11. High-Level Waste - Phase 1B Cost (Category I/AI).

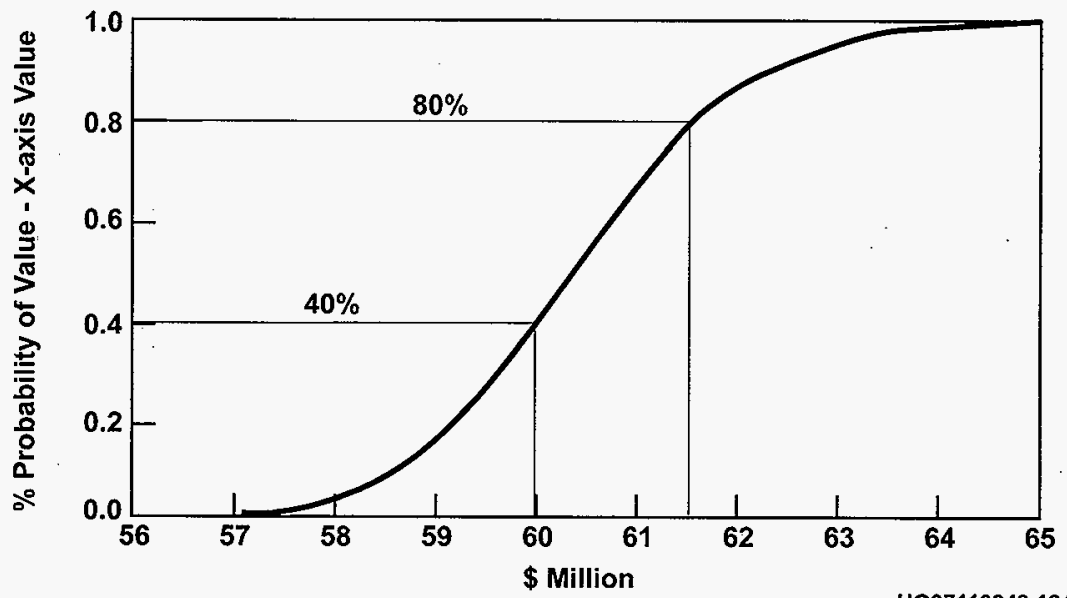

HG97110249.124

2017-11

\subsubsection{Low-Activity Waste Feed Delivery Risk Analysis}

The risk modeling suggests a $35 \%$ program certainty that the project can be executed for the $\$ 375$ million budgeted level. As shown in Figure 12, the major cost risk and driver is the possibility of additional requirements for characterization laboratory methods for complex $\mathrm{LAW}$ analysis.

At the recommended program certainty of $80 \%$, a $\$ 4$ million increase for a total of $\$ 379$ million is required to compensate for the specific major cost risks and drivers and other activities for the overall LAW program.

\subsubsection{Infrastructure Risk Analysis}

Utility and other infrastructure costs added if HLW, LAW, and Immobilized Waste project items experience delays in construction and electrical and waste disposal rates variability are the major areas of concern. At the updated baseline budget of $\$ 469$ million, there is $55 \%$ program certainty as determined by the risk analysis modeling. An $\$ 8$ million increase to compensate for these major cost risks and drivers will increase the recommended program certainty to $80 \%$ or $\$ 477$ million. This is shown in Figure 13. 
HNF-2017 Rev 0

Figure 12. Low-Activity Waste - Phase 1B Cost (Category I/II).

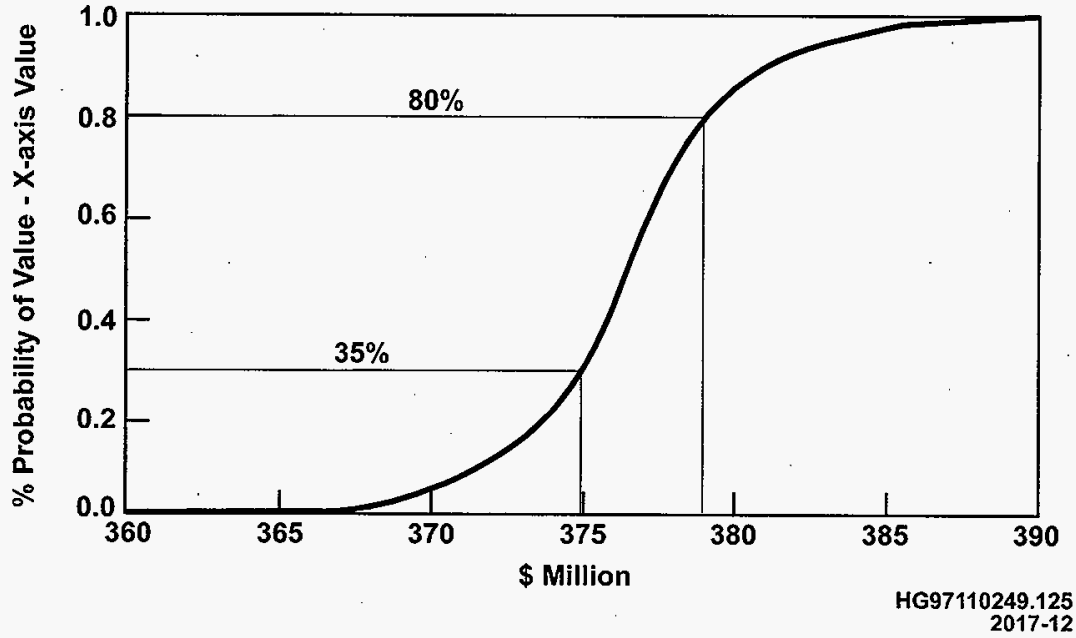

Figure 13. Infrastructure - Phase 1B Cost (Category I/II).

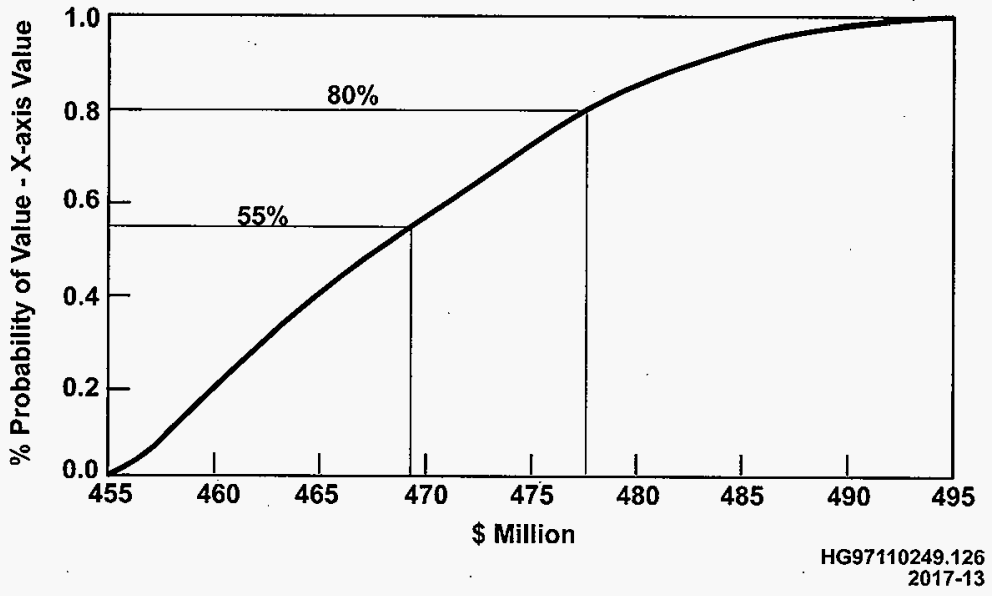




\subsubsection{Immobilized Waste Risk Analysis}

Risks are driven by the first-of-a-kind nature of interim IHLW and ILAW facilities. The construction, equipment procurement and installation, and start up operations have potentials to increase costs above project budgeted values. As shown in Figure 14, the program certainty as modeled is $40 \%$ at budgeted level of $\$ 357$ million. At the recommended program certainty of $80 \%$, an $\$ 11$ million increase is required or $\$ 368$ million.

Figure 14. Immobilized Waste - Phase 1B Cost (Category I/II).

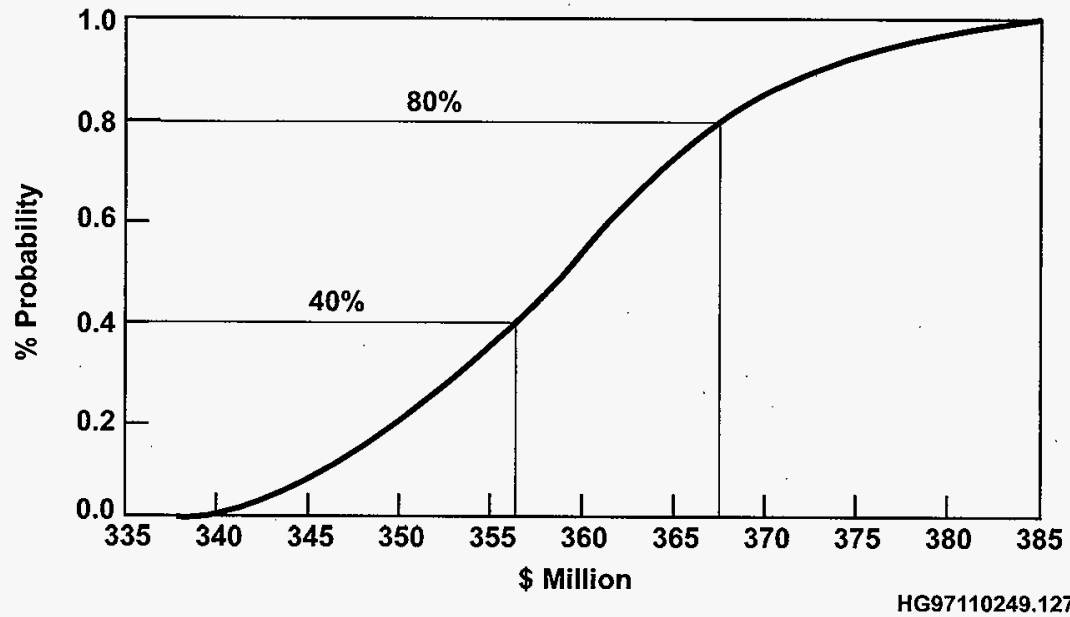

2017-14

\subsection{RISK ANALYSIS - PHASE 1B - INTEGRATED PROJECT}

There are risk issues of an uncertain and integrated nature (category III) as defined in Section 2.2.2. that were analyzed to assure reasonable project execution success. The major areas of risk that were evaluated are Process, Sampling, Authorization Basis, Equipment, Operation Readiness Reviews, Facilities, and External Issues. The significant risks include the following:

- The DST transfer systems have many common mode failures. Reliability, availability, and maintainability analysis is not yet complete.

- Major components of the retrieval and transfer systems may encounter unexpected problems during operation. The problems could be due to failure of the equipment or due to the equipment not meeting the project requirements. 
- Unplanned radiological exposures may occur during removal of existing equipment from the tanks or transfer systems or installation of new components or system.

- Plugging of transfer pipelines is a potential risk.

These risks are described in greater detail in TWRS Retrieval and Disposal Mission Critical Risk List as identified in HNF-2019 (Boston and Jordan 1998) and within HNF-2021 (Payne et al. 1998) and are being managed.

The overall Phase 1B Retrieval and Disposal Project needs to be increased by $\$ 162$ million to reach a $50 \%$ program certainty consistent with the baseline plan, as shown in Figure 15. To reach the recommended program certainty of $80 \%$, an additional $\$ 62$ million is required for a total of $\$ 224$ million. All of this is an increase to the allowance for project specifics risks of $\$ 24.5$ million in Section 4.2 .

Table 13 provides a sample of risks identified and considered in the analysis.

Figure 15. Category III Risks.

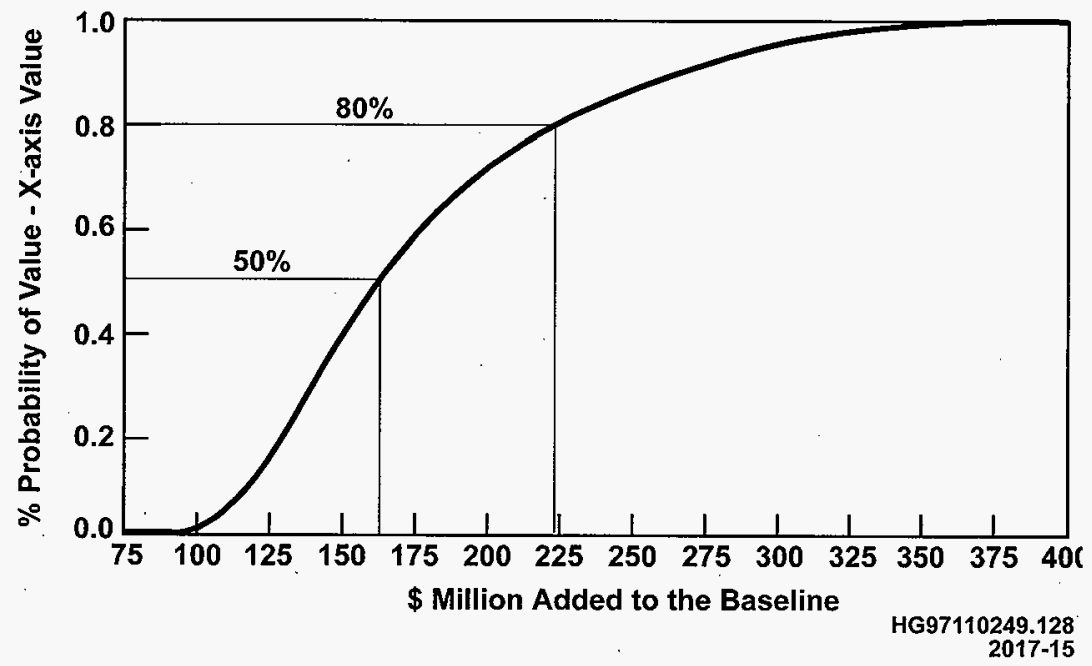


Table 13. Integrated Program Risks (Category III). (3 Sheets)

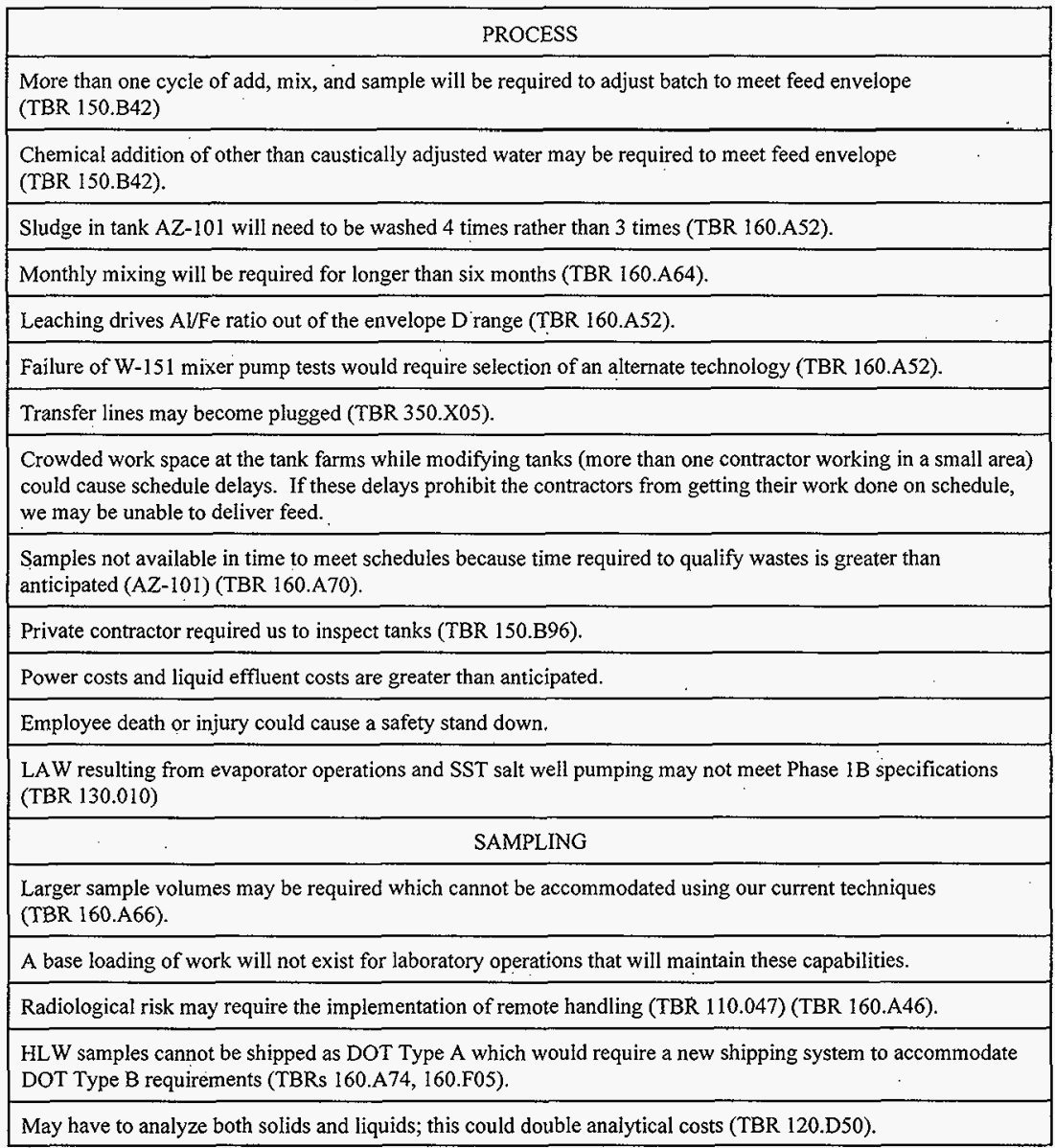


HNF-2017 Rev 0

Table 13. Integrated Program Risks (Category III). (3 Sheets)

\begin{tabular}{|c|}
\hline AUTHORIZATION BASIS \\
\hline Insufficient DST space is available to receive return streams if compatibility issues arise A15 (TBR 350.X05). \\
\hline Authorization Basis issue regarding transfer to waste from tank 102-SY to 105-AW (TBR 130.P50). \\
\hline Other Authorization Basis delays by RL. \\
\hline Unanticipated USQ discoveries: \\
\hline EQUIPMENT \\
\hline Spare transfer pump not suitable; need to purchase a new one (TBR 120.C30). \\
\hline Capacitor bank upgrade required for project W-519. \\
\hline Mixer pump not adequate to mobilize solids for either washing and leaching or retrieval (TBR 160.A52). \\
\hline $\begin{array}{l}\text { Operations and/or maintenance plans. are not adequate and a maintenance related condition occurs that cause loss } \\
\text { of use of critical equipment (TBR 130.B15). }\end{array}$ \\
\hline $\begin{array}{l}\text { Outyear maintenance execution: staffing levels and material needs to support feed delivery mission are } \\
\text { insufficient to meet feed delivery schedule (TBR } 130 . \mathrm{B} 16 \text { ). }\end{array}$ \\
\hline Note: The previous two issues will be combined. \\
\hline $\begin{array}{l}\text { Evaporator fails or is not funded resulting in insufficient DST space for staging, etc. (DOE decisions to fund or } \\
\text { not). Feed delivery schedule cannot be met (TBR 130.B40). }\end{array}$ \\
\hline $\begin{array}{l}\text { Project W-211 is not providing spares; critical safety related spares are not identified and are not planned to be } \\
\text { provided (TBR 120.B58). }\end{array}$ \\
\hline OPERATION READINESS REVIEW \\
\hline $\begin{array}{l}\text { All Operation Readiness Reviews will not be completed within allotted schedule time of } 30 \text { days; may take } \\
45 \text { days. }\end{array}$ \\
\hline FACILITIES \\
\hline $\begin{array}{l}\text { The schedule for canister storage building operations may conflict with TWRS activities to modify and utilize the } \\
\text { CSB for IHLW storage. (entire TBR } 440 \text { series). }\end{array}$ \\
\hline Change from 3 meter canister to 4.5 meter canister requiring new facilities (entire TBR 440 series). \\
\hline $\begin{array}{l}\text { We have been asked by DOE to convert LAW storage facilities to disposal facilities (letter has been prepared for } \\
\text { DOE signature) (TBR } 460.065 \text { ). }\end{array}$ \\
\hline
\end{tabular}


Table 13. Integrated Program Risks (Category III). (3 Sheets)

\begin{tabular}{|l|}
\hline \multicolumn{1}{|c|}{ EXTERNAL ISSUES } \\
\hline Other stand downs, i.e., Defense Nuclear Facilities Safety Board \\
\hline Price Anderson Considerations \\
\hline Fines and Penalties associated with ES\&H non-compliances. \\
\hline $\begin{array}{l}\text { Other unplanned initiatives by DOE - new Orders, Secretarial Initiatives, etc. (e.g., Chemical Vulnerability, } \\
\text { Emergency Preparedness). }\end{array}$ \\
\hline
\end{tabular}

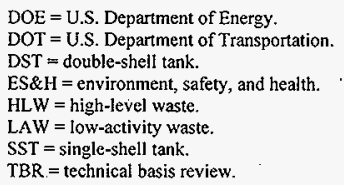

The time-phasing of the risk allowance $(\$ 224 \mathrm{M})$ was based primarily on the overall funding profile for the TWR Project, with the intent of establishing a constant funding profile that would provide for stability of planning and execution. This is shown in Table 14. basis.

Additional risk analysis will be performed to quantify and adjust the risk on an annual

Table 14. Time Phasing of Risk Analysis.

\begin{tabular}{|c|c|c|c|c|c|c|}
\hline \multicolumn{7}{|c|}{ Dollars in millions } \\
\hline FY 1998 & FY 1999 & FY 2000 & FY 2001 & FY 2002 & $\begin{array}{c}\text { FY 2003- } \\
2011\end{array}$ & Total \\
\hline$\$-$ & $\$-$ & $\$ 10$ & $\$ 40$ & $\$ 40$ & $\$ 134$ & $\$ 224$ \\
\hline
\end{tabular}

\subsection{CRITICAL PATH ANALYSIS}

The delivery of both HLW (Section 4.4.2) and LAW (Section 4.4.3) feed is a medium to high risk. The waste feed delivery prior to June 2002 appears to be achievable with a minimal near term investment in the area of HLW feed delivery and a replanning in the next PBS cycle for the W-211 acceleration to support LAW feed delivery.

Immobilized Waste Projects (Section 4.4.5) have a medium to high risk since there are challenges for the DOE to break down barriers and streamline the project authorization as well as the congressional appropriations process. 
The completion of the site development portion of the Infrastructure Project (Section 4.4.5) is a medium risk.' This will need to be closely monitored so that the project has a timely response to work around plans for site development.

Overall, the TWRS Phase $1 \mathrm{~B}$ schedule is a medium to high risk since there is minimal float on the activities associated baselined.

Schedule acceleration initiatives are offered in each project area which could modify the risk assessment to low to medium. An acceleration of efforts adding $\$ 0.5$ million to FY 1998 , $\$ 7.0$ million to FY 1999 , and $\$ 14.8$ million to FY 2000 would provide an additional float in each of the project areas. The time phased costs are shown in Table 15.

Table 15. Critical Path Analysis Risk Allowance.

\begin{tabular}{|l|rrrrrrrr|r|}
\hline & \multicolumn{7}{|c|}{ Dollars in millions } \\
\cline { 2 - 10 } & FY 98 & FY 99 & FY 00 & FY 01 & FY 02 & FY 03 & Total \\
Added float for HLW AZ Feed & - & 0.5 & & $(0.5)$ & & & $\$ 0.0$ \\
Delivery & & & & & & & & \\
$\begin{array}{l}\text { Added float for LAW Feed } \\
\text { Delivery AW-101 }\end{array}$ & - & 1.2 & 1.7 & $(0.7)$ & $(1.9)$ & $(0.3)$ & 0.0 \\
$\begin{array}{l}\text { Added float for Immobilized Waste } \\
\text { Project W-464/W-465 }\end{array}$ & 0.5 & & 5.3 & 13.1 & $(8.2)$ & $(10.7)$ & & 0.0 \\
Total Allowance for Risk & 0.5 & 7.0 & 14.8 & $(9.4)$ & $(12.6)$ & $(0.3)$ & $\$ 0.0$ \\
\hline
\end{tabular}

HLW $=$ high-level waste.

$\mathrm{LAW}=$ low-activity waste.

These risks are also captured in the TWRS Retrieval and Disposal Mission Critical Risk List as identified in HNF-2019 (Boston and Jordan 1998). The most critical are discussed in detail in HNF-2021 (Payne et al. 1998).

\subsubsection{Level 0 Logic}

The TWRS Program Level 0 Logic (Figure 16) provides the road map to accomplish the entire TWRS mission, including both Phase 1 and 2 of private contractor work. The RTP activities for Phase $1 \mathrm{~B}$ will be focusing on the safe retrieval of tank waste through the installation of mixer pumps in DSTs to mobilize the waste in the tanks (W-211, initial DST retrieval system), sample the waste, characterize the contents and ultimately transfer the waste to the private contractors' feed tanks through an upgraded piping system (W-314). After processing of the waste by the private contractors, the ILAW will be disposed of at Hanford and the available. The storage function is considered to be an ongoing activity. 


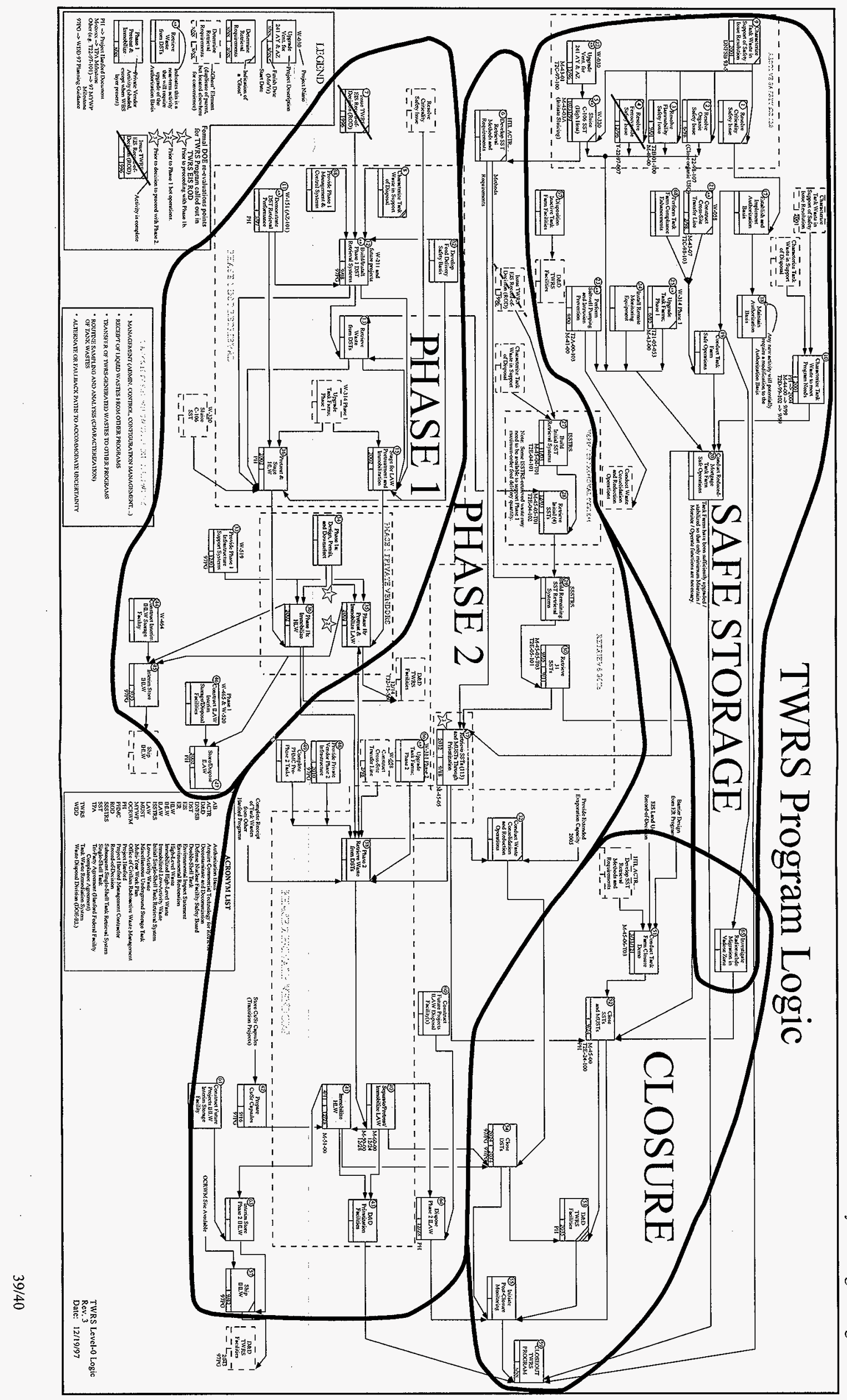

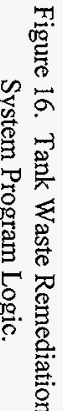


Figure 17 displays the master schedule of key events to execute the Phase 1B Level 0 logic, consistent with the detailed Primavera resource-loaded schedules.

\subsubsection{High-Level Waste}

The schedule indicates that the first batch of HLW which will be provided to the private contractors has less than three months of float as shown in Table 16.

Table 16. High-Level Waste Float.

\begin{tabular}{|l|l|c|}
\hline \multicolumn{1}{|c|}{ Batch number } & Tank & Total float (days) \\
\hline 1,2 & AZ-101 & 83 \\
\hline 3,4 & AZ-102 & 74 \\
\hline $5,6,7,8,9$ & AY-102 & 221 \\
\hline $10,11,12$ & C-104 & 461 \\
\hline
\end{tabular}

An opportunity to improve this schedule by increasing the float to six months is to conduct activities in parallel instead of executing them sequentially. These include AZ-101 construction activities in parallel with tank characterization and waste confirmation activities rather than construction following waste confirmation activities.

The cost impact would be an increase of $\$ 500 \mathrm{~K}$ in FY 1999 offset by a decrease of $\$ 500 \mathrm{~K}$ in FY 2001 as shown in Table 15. The additional float is warranted by uncertainties associated with the performance of sludge washing (washing efficiency and settling times) and waste composition.

Figure 18 summarizes pictorially the current HLW batches 1 and 2 critical path. The Primavera critical path schedule to the first feed batch delivery in FY 2002 may be found in Appendix B. 
Figure 17. Readiness-to-Proceed Site Master Baseline Schedule. (Sheet 1 of 2)

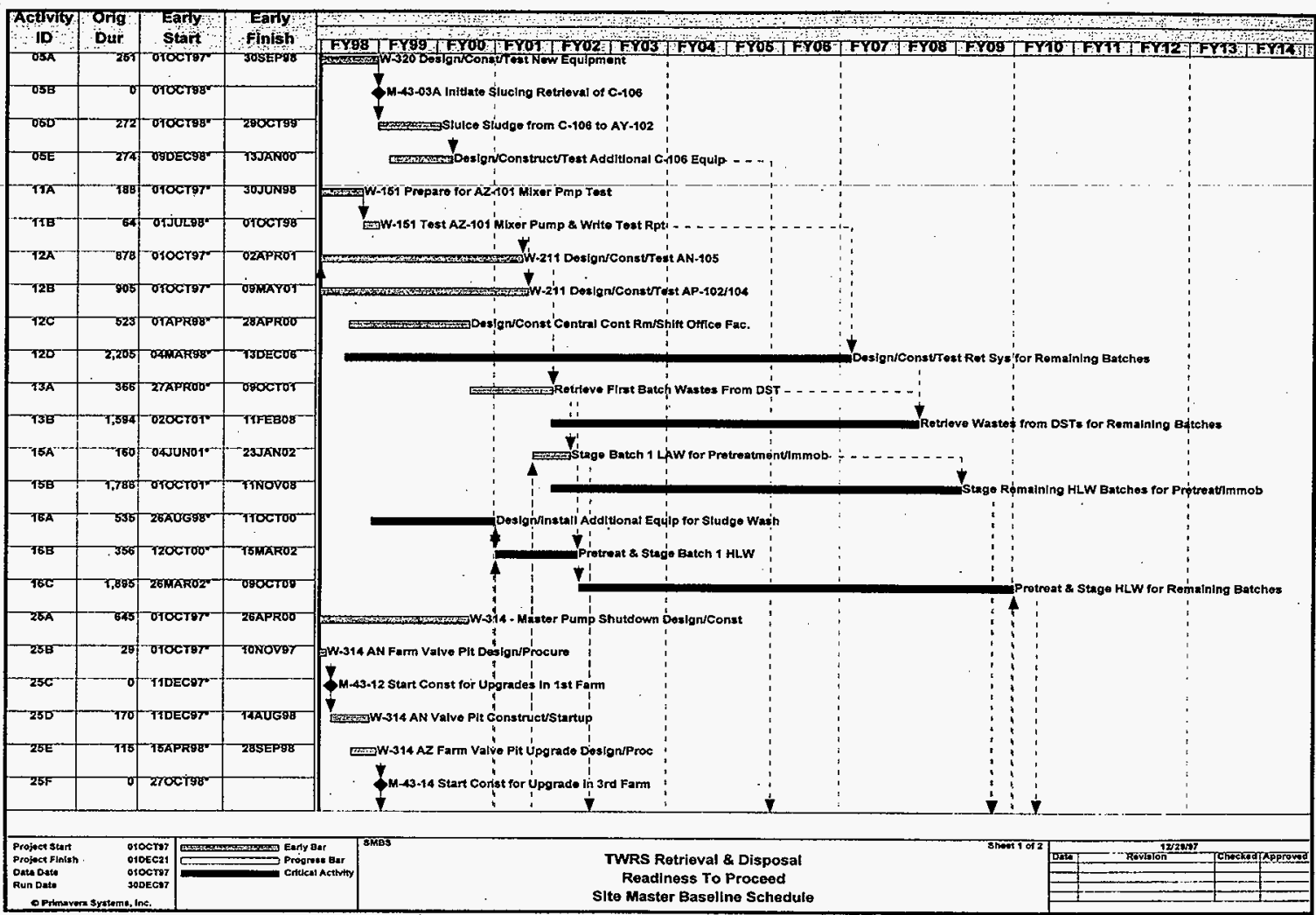


Figure 17. Readiness-to-Proceed Site Master Baseline Schedule. (Sheet 2 of 2)

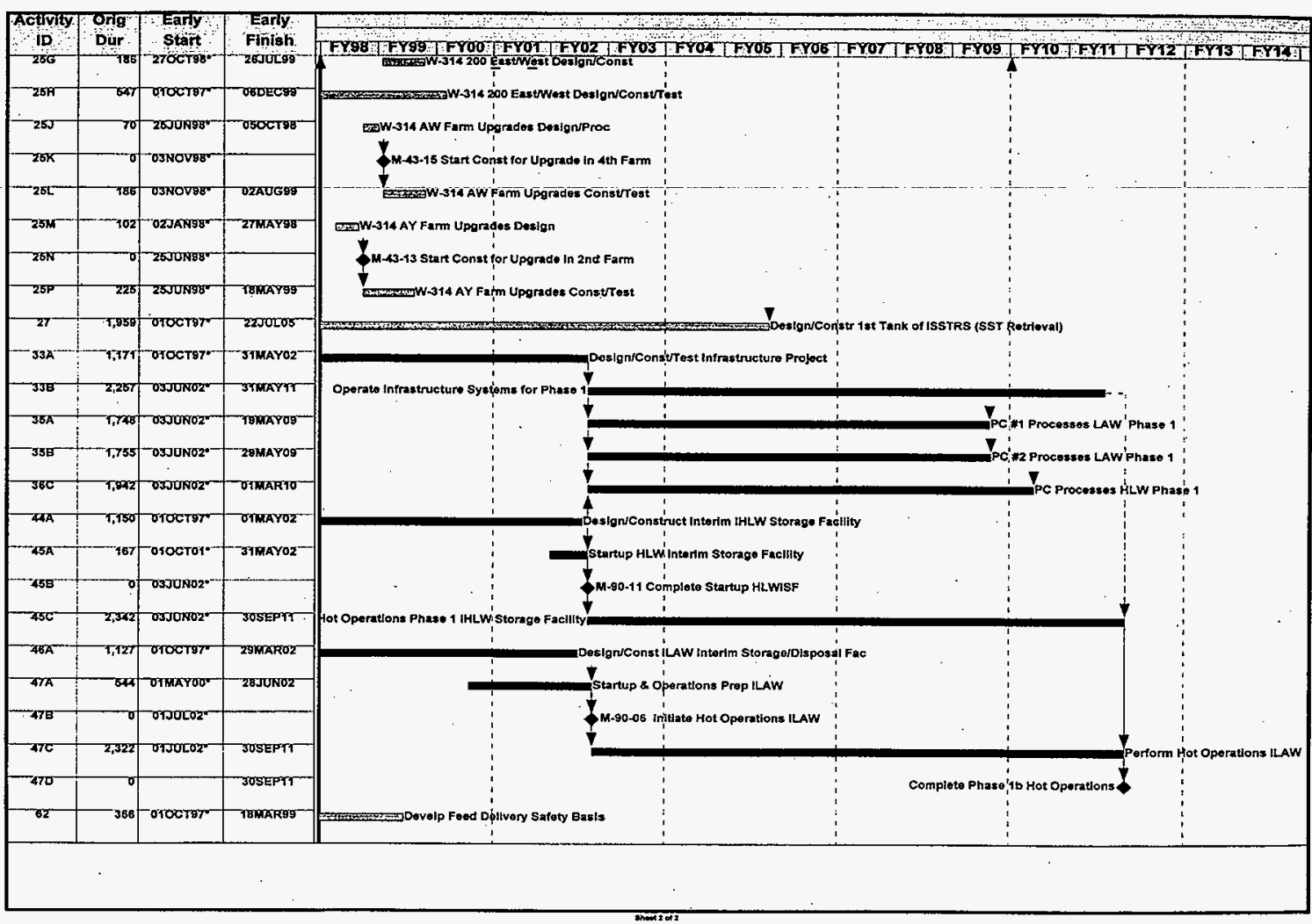


Figure 18. High-Level Waste Batches I and 2 Critical Path Schedule.

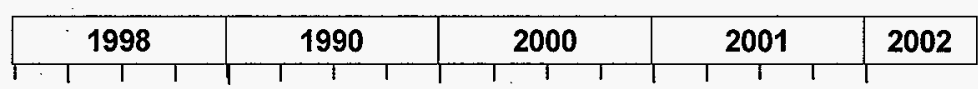

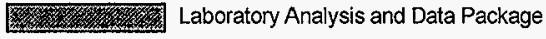

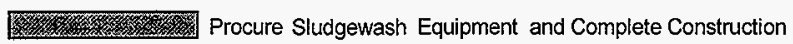

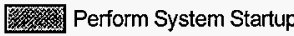

Conduct Field Assessments for ORR AZ-101

Operations and ORR Team Reconcile Findings

3.

Tank Content Feed Envelope Preparation and Samples to PC

PC Conduct Waste Form Qualification AZ-101

Transfer Batch \#1 (AZ-101 136,000 gal)

\section{- Total feed delivered for both contractors = 234 MT sodium}

\footnotetext{
DOE = U.S. Department of Energy

MT $=$ Metric tons

ORR = Operational Readiness Review

PC = Private Contractor
}

Readiness Assessment 


\subsubsection{Low-Activity Waste}

The schedule indicates that the first batch of LAW feed which will be provided to the private contractors has six months of float in the schedule as shown in Table 17. However, subsequent batches ( 3 and 4 ) have less than one month of float. An opportunity to improve the schedule may be to accelerate W-211 activities for tank AW-101 (third LAW batch) and beyond. From a cost viewpoint, the definitive design for AW-101 would be accelerated from the June 1999 start by six months which would increase FY 1999 costs approximately $\$ 1.2$ million and increase FY 2000 by $\$ 1.7$ million with reductions in the outyears to offset this acceleration, as shown in Table 15.

Table 17. Low-Activity Waste Float.

\begin{tabular}{|l|l|c|c|}
\hline $\begin{array}{c}\text { Batch } \\
\text { number }\end{array}$ & \multicolumn{1}{|c|}{ Tank(s) } & $\begin{array}{c}\text { Total float for private } \\
\text { contractor \#1 }\end{array}$ & $\begin{array}{c}\text { Total float for private } \\
\text { contractor \#2 }\end{array}$ \\
\hline 1 & AN-105 & 139 & 131 \\
\hline 2 & AN-104 & 166 & 163 \\
\hline 3 & AW-101 & 39 & 19 \\
\hline 4 & AN-103 & 43 & 34 \\
\hline 5 & AP-101/AW-104 & 134 & 134 \\
\hline 6 & AY-101 & 144 & 209 \\
\hline 7,8 & AN-107 & 63 & 88 \\
\hline 9 & AN-102 & 9 & 8 \\
\hline 10 & AN-106 & 95 & 93 \\
\hline 11 & SY-101 & 64 & 68 \\
\hline 12 & SY-103 & 161 & 164 \\
\hline
\end{tabular}

Additional tight schedules or low float for several batches ( 7 and beyond) of LAW are a result of small batches of waste feed delivered to meet minimum order quantities of waste specified in the contract, and private contractor processing rates that consume the small batches faster than the next feed batch can be delivered.

The TWRS contractor recommends providing the flexibility to deliver additional waste beyond minimum order quantities as needed to result in longer processing cycle times between feed batches. An alternative is specifying a time between specific batches to provide sufficient time to assure delivery of feed.

Figure 19 summarizes pictorially the LAW batch 1 . The Primavera critical path schedule to the first feed batch delivery in FY 2002 may be found in Appendix B. 


\begin{tabular}{|c|c|c|c|c|}
\hline 1998 & 1999 & 2000 & 2001 & 2002 \\
\hline
\end{tabular}

f

Design, Construct, Start Up AN-105 Retrieval Systems

Design, Construct, Start Up AP-102/104 DOE ORR

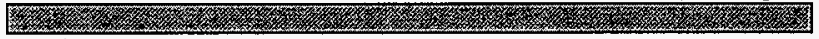

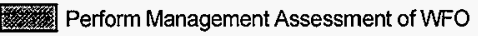

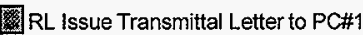

Transfer AN-105 Waste from

AP-102 to AP-106 PC\#1

RL Issue Transmittal Letter to PC\#2

Transfer AN-105 Waste from AP-104 to AP-108 to PC \#2

- Total feed delivered for both contractors $=1,207 \mathrm{MT}$ sodium

- These batch numbers are for sequential purposes only and are not tied to batch numbers as stated in the TWRS OUP

DOE = U.S. Department of Energy

MT $\quad$ Motric tons

ORR $\quad$ = Operational Readiness Review

PC = Private Contractor

RL $\quad$ = U.S. Department of Energy, Richland Operations Office

TWRS OUP $=$ TWRS Operations and Utilization Plan

TWRS = Tank Waste Remediation System

2017-19

WFO

= Work for Others 


\subsubsection{Immobilized Waste}

Immobilized waste consists of two facilities: an ILAW disposal facility and an IHLW storage facility.

The schedule for both of these facilities indicates that there is virtually no float through startup in June 2002. In addition, the delays to the Canister Storage Building, which is the preferable immobilized HLW storage facility for Phase $1 \mathrm{~B}$, will need to be evaluated and places facility startup schedules at risk.

This schedule has an opportunity to improve if two events could occur:

a. The DOE modify the process of waiting a year and a half after project validation before receiving capital funding. This would allow for both immobilized waste projects (W-464 [IHLW] and W-465 [ILAW]) to start detailed design in FY 1999 versus the current plan to start in FY 2000.

b. The budget submittal (FY 1999 Project Baseline Schedule) would be recast to accommodate this acceleration. This would be an incremental increase to FY 1998 of $\$ 0.5$ million, an increase to the current Project Baseline Schedule submittal in FY 1999 of approximately $\$ 5.3$ million and \$13.1 million in FY 2000 with an equal reduction in FY 2001 through FY 2002 as shown in Table 15.

The PHMC team recommends that the above two improvement areas be implemented to reduce the overall risk and provide increased schedule margin. Projects W-464 and W-465 should be addressed as an integral part of the FY 2000 PBS submittal for life cycle effects.

Figure 20 outlines the immobilized waste major events. The Primavera critical path schedule to support the first feed batch delivery in FY 2002 may be found in Appendix B.

\subsubsection{Infrastructure}

The site development portion of the Infrastructure Project must be completed by December 31,1999, to support the private contractor's construction start. There is virtually no float in this portion of the schedule. The remaining infrastructure elements (i.e., electricity and water) are not critical path to either cold or hot startup of the Phase $1 \mathrm{~B}$ private contractor facilities. 


\begin{tabular}{|l|l|l|l|l|l|l|ll|lll|l|l|l|}
\hline \multicolumn{2}{|c|}{1998} & & \multicolumn{2}{|c|}{1999} & & 2000 & & 2001 & & 2002 \\
\hline
\end{tabular}

图 Prepare Conceptual Design to $90 \%$

Prepare Final CDRNalidation Package
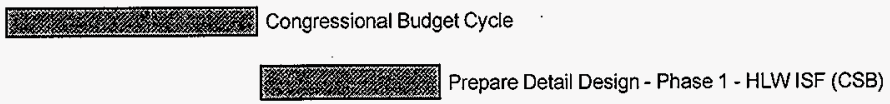
HNF-2017 Rev 0

Working double shifts on the site development activities could mitigate this risk. This may increase the project total estimated costs since the validated contingency amount may not support this double shifting plus other unplanned events.

The PHMC team recommends that the project proceed at risk with the understanding that double shifting could be used to create schedule float in FY 1999/2000 and additional capital funding required.

Figure 21 pictorially summarizes the Infrastructure major events. The Primavera critical path schedule to support the first feed batch delivery in FY 2002 may be found in Appendix B.

\subsection{PROGRAMMATIC RISKS}

Some technical risks are of a programmatic nature (Category 4) as defined in Section 2.2.2. These are events driven by a technical issue which has a small probability of occurrence, but cannot be predicted or priced without additional information or understanding (Category 4). Examples including these as discussed in HNF-2021 (Boston and Jordan 1998) are:

- $\quad$ Feed batch size and contractor processing rates may require feed delivery rates exceeding the currently defined waste qualification process.

- Expected waste volume generation and resultant DST tank inventory leave little flexibility in the use and allocation of DST space for feed storage.

- Unforseen issues may lead to additional design requirements as the authorization basis is expanded to meet the retrieval and immobilized product storage mission.

- Another major safety issue will be identified.

- The potential for significant changes in the current schedule for the fuel movement from K-Basins will affect TWRS ability to support immobilized highlevel waste receipt and storage.

- U. S. Environmental Protection Agency (EPA)/Washington State Department of Ecology (Ecology) may deny the de-listing petition.

As shown these are risks with a finite probability of occurrence but cannot be priced, thus, will be managed carefully in accordance with the TWRS Risk Management Plan (Zimmerman 1998b). 


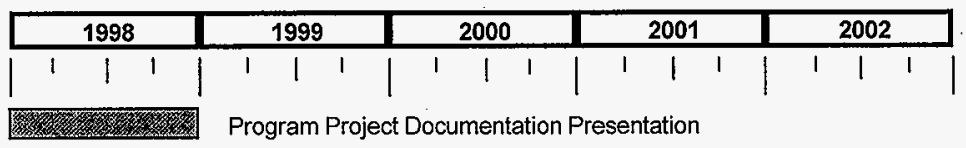

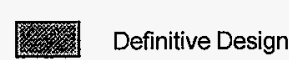

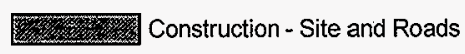

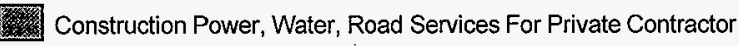

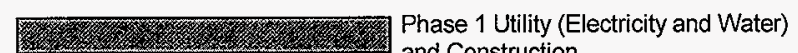
and Construction

- Commence Fuil Operations of Support

System Phase 1 Processing Facility

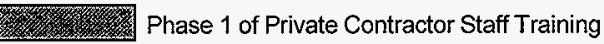


HNF-2017 Rev 0

\subsection{FY 1998 AND FY 1999 TARGET FUNDING ANALYSIS}

The analysis to this point has focused on the changes to the total Phase $1 \mathrm{~B}$ program and TWRS Project life cycle costs. Each of the areas discussed has a corresponding impact on the FY 1998 and FY 1999 budget requirements. The RTP plan as presented provides a solution which retains a balanced position or no additional funds required for FY 1998. In FY 1999, however, a need is demonstrated for $\$ 20$ million with offset opportunities of $\$ 10$ million defined yielding a net added requirement of $\$ 10$ million. Table 18 presents a summary of these changes.

Table 18. Fiscal Year 1998 and Fiscal Year 1999 Summary. (Dollars in millions)

\begin{tabular}{|c|c|c|}
\hline & FY 1998 & FY 1999 \\
\hline Budget requirements (MYWP) & $\$ 332.6$ & $\$ 339.7$ \\
\hline $\begin{array}{l}\text { Existing shortfall } \\
\text { - Compliance unfunded (Section 4.6) } \\
\text { - Vadose zone mapping/logging (Section 4.6) } \\
\text { - PBS compliance update (Section 4.6) }\end{array}$ & $\begin{array}{l}31.0 \\
4.0 \\
--\end{array}$ & $\begin{array}{l}(1.5) \\
4.0 \\
3.9\end{array}$ \\
\hline $\begin{array}{l}\text { Budget requirements (pre-Phase 1B analysis) } \\
\text { Phase 1B shortfall analysis } \\
\text { - Updated B/L to meet critical path (Section 4.1.2) } \\
\text { - Retrieval scope transfer shortfall (Section } 4.3 \text { ) } \\
\text { S/T Phase IB shortfall analysis }\end{array}$ & $\begin{array}{l}367.6 \\
8.5 \\
\frac{(3.8)}{4.7}\end{array}$ & $\begin{array}{l}346.1 \\
18.1 \\
\frac{(5.1)}{13.0}\end{array}$ \\
\hline Requirement at $50 \%$ certainty & 372.3 & 359.1 \\
\hline $\begin{array}{l}\text { - Project specific risks (Categories } 1 \text { and II) (Section 4.2) } \\
\text { - Integrated program risks (Category III) (Section 4.3) } \\
\text { - Critical path analysis (Section 4.4) } \\
\text { S/T allowance for risk }\end{array}$ & $\frac{0.5}{0.5}$ & $\frac{7.0}{7.0}$ \\
\hline Requirement at $80 \%$ certainty & 372.8 & 366.1 \\
\hline $\begin{array}{l}\text { Recommended actions } \\
\text { - Target funding analysis (Section 4.6) } \\
\text { - Vadose zone mapping/logging (Section 4.6) } \\
\text { - Compliance unfunded renegotiation (Section 4.6) }\end{array}$ & $\begin{array}{l}(5.2) \\
(4.0) \\
(31.0)\end{array}$ & $\begin{array}{l}(4.3) \\
(4.0) \\
1.5\end{array}$ \\
\hline Updated budget requirements & 332.6 & 359.3 \\
\hline Delta to MYWP & 0.0 & 19.6 \\
\hline Cost reduction opportunities & --- & $(10.0)$ \\
\hline
\end{tabular}

$\mathrm{B} / \mathrm{L}=$ baseline

$\mathrm{FY}=$ fiscal year
MYWP $=$ multi-year work plan. $\mathrm{S} / \mathrm{T}=$ subtotal

It is well documented and understood that $\$ 31.0$ million of compliance work is unfunded and that vadose zone mapping and logging is requesting an additional $\$ 4.0$ million in FY 1998 and FY 1999. This plan does not address resolution but simply acknowledges the need to 
resolve. During the process of completing the PBS submittal, $\$ 3.9$ million was added in FY 1999 as a result of incorporating a directed change notice from FDH which resulted in deferment of work scope from FY 1998 to FY 1999. The FY 1999 ( $\$ 1.5 \mathrm{M})$ compliance unfunded is a combination of moving $\$ 4.5$ million unfunded FSAR from FY 1999 to FY 1998 which is partially offset by $\$ 3$ million for As-Built drawings. This established the baseline for the Phase $1 \mathrm{~B}$ analysis.

The updated baseline to meet the critical path increases the FY 1998 and FY 1999 requirements by approximately $\$ 27$ million as shown in Table 18 . The drivers are the need to address retrieval and feed process systems definitions and planning for future projects for later waste feed batches. Table 19 provides a summary of detail costs. These costs are partially offset by an approximate $\$ 9.0$ million reduction in the Characterization base load support as discussed in Section 4.1.4.2.

Table 19. Updated FY 1998 - FY 1999 Baseline to Meet Critical Path. (Dollars in millions)

\begin{tabular}{|l|r|r|}
\hline & FY 1998 & FY 1999 \\
\hline - Project management and administration & $\$ 0.4$ & $\$ 0.4$ \\
- Feed process systems definition & 4.1 & 7.7 \\
- Retrieval systems definition & 2.1 & 2.3 \\
- ISSTRS & -- & $(1.3)$ \\
- Future DST retrieval projects & 1.0 & 2.7 \\
- Phase 1 operations - DST & 0.3 & 1.1 \\
- Phase 1 retrieval safety operation & 0.4 & 0.7 \\
- W-320/W-151/W-211/W-314 & 0.3 & 2.7 \\
Retrieval subtotal & 8.6 & 16.3 \\
Infrastructure & $(0.1)$ & 0.9 \\
Immobilized Waste & --- & 0.5 \\
- Escalation & --- & 0.5 \\
\hline Phase 1B logics adjustments & $\$ 8.5$ & $\$ 18.1$ \\
\hline
\end{tabular}

DST $=$ double-shell tank

$\mathrm{FY}=$ fiscal year.

ISSTRS $=$ initial single-shell tank retrieval system.

The critical path analysis (Section 4.4) highlighted the need to accelerate the HLW AZ-101 and LAW AW-101 feed deliveries as well as Immobilized Waste projects W-464 and $\mathrm{W}-465$. This added requirement is $\$ 7.5$ million.

Recognizing that the FY 1998/1999 congressional targets have little flexibility to change funding this target funding analysis was prepared using cost reduction opportunities and recognizing alternative strategies. Scope deferrals to FY 2000 which do not impact the feed delivery critical path events and have negligible impact on the overall level of confidence are proposed and summarized in Table 20. 
Table 20. Target Funding Analysis. (Dollars in millions)

\begin{tabular}{|l|r|r|r|}
\hline & FY 1998 & FY 1.999 & FY 2000 \\
\hline Retrieval Feed Processing System Definition & $(\$ 2.4)$ & $(\$ 2.4)$ & $\$ 4.8$ \\
Retrieval System Definition & $(1.6)$ & $(1.2)$ & 2.8 \\
Future DST Retrieval Project & $(0.7)$ & $(1.2)$ & 1.9 \\
ILAW Performance Assessment & $(0.5)$ & 0.5 & $\cdots$ \\
\hline Total & $(\$ 5.2)$ & $(\$ 4.3)$ & $\$ 9.5$ \\
\hline \multicolumn{1}{|c|}{ DST = double-shell tank. } & & & \\
FY = fiscal year \\
ILAW = immobilized low-activity waste.
\end{tabular}

The cost reduction opportunity identified assumes that the $\$ 10$ million TWRS share of the site indirect rate reduction will materialize in FY 1999 consistent with FY 1998 planning. Opportunities to further reduce or eliminate the FY 1999 shortfall of $\$ 10$ million are being explored. However, it is felt that reductions to this plan will cause a significant increase in risk and corresponding impact on confidence in achieving the mission goals.

\subsection{COST REDUCTION OPPORTUNITIES}

The analysis of the Phase 1B requirements to achieve mission goals establishes an additional requirement of $\$ 458$ million to the TWRS project life cycle costs. Potential opportunities and alternative strategies are being explored to mitigate this added requirement. Two have been quantified and are included in this analysis: (1) site indirect and benefit rate reductions and (2) enterprise resource planning forecasted efficiencies. The combined offset is projected to be $\$ 200$ million.

The reduction in indirect costs from the FY 1998 budgeted level of $\$ 278$ million to a performance committed $\$ 260$ million could reduce the budgeting rates and factors applied to base costs in future years. With no additional savings or by maintaining a constant set of rates and factors, $\$ 140$ million in savings could be achieved through FY 2011.

The enterprise resource planning efficiencies are forecasted savings of implementing the new financial, procurement, and work management systems. An additional savings to the TWRS project of $\$ 60$ million could be generated through these efficiencies as estimated by the PHMC team.

A spread of the cost reduction by year is found in Appendix A, Financial Analysis Summary Detail.

\subsection{COMMON OCCUPATIONAL CODE STRUCTURE ANALYSIS}

Figure 22 is a graphical display of the Phase $1 \mathrm{~B}$ resource-loaded schedules by common occupational code structure (COCS) for the $\$ 2.013$ billion baseline. 
Overall, the significant increase in operators and crafts in FY 2001 and FY 2002 (including some temporary increase in engineering support) is to.support the training of private contractor personnel. These personnel will transition to the private contractor once trained, which explains the staff reduction in FY 2003. There is also temporary increase in engineering as the FY 2002 feed processing startup is approached. Other than these expected anomalies, the staffing loading represents a manageable steady decline as the mission is completed. The risk of executing per the disciplines required is acceptable. 
Figure 22. Phase 1B Resource-Load Schedules by Common Occupational Code Structure.

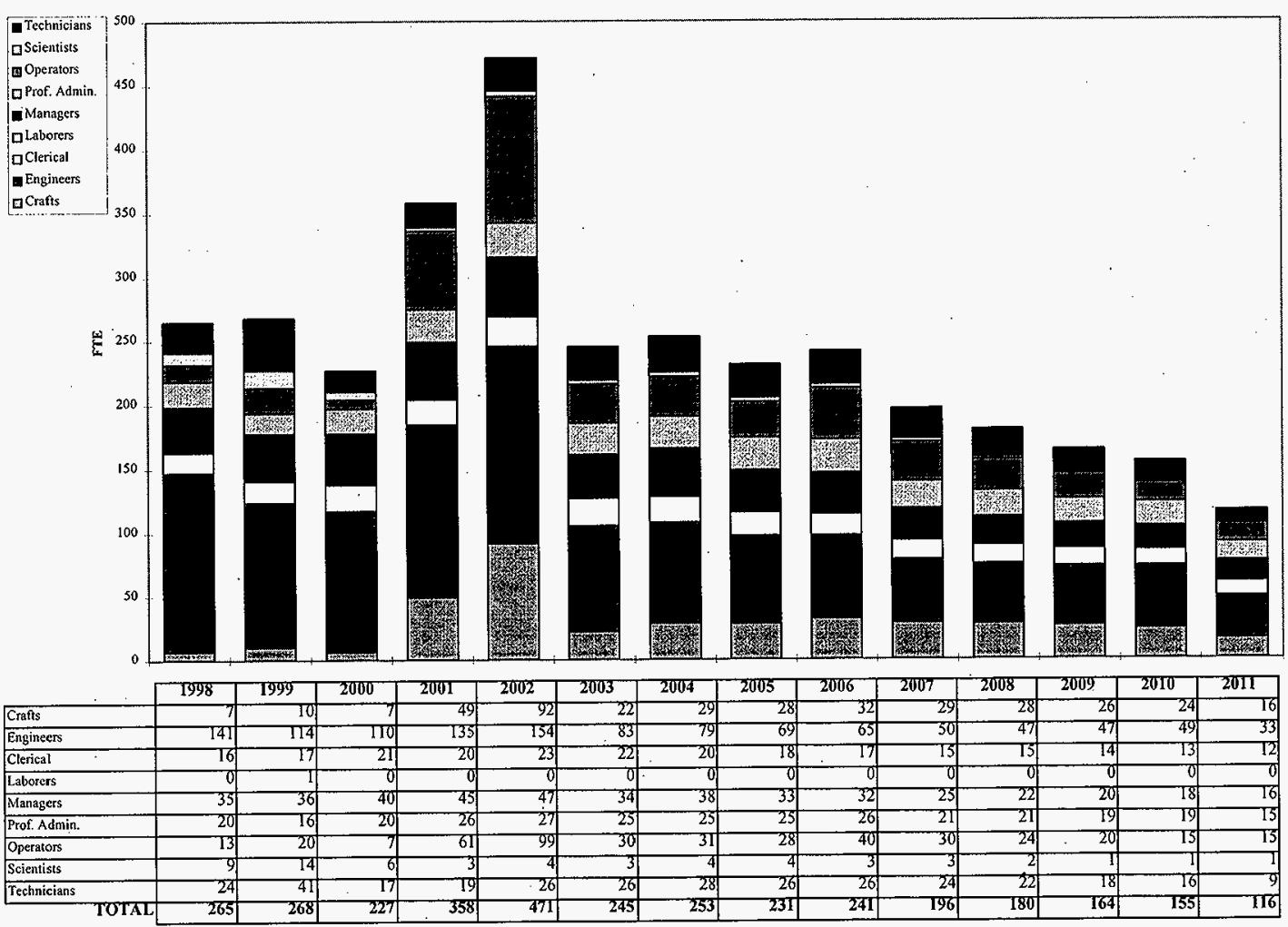


HNF-2017 Rev 0

\subsection{CONCLUSION}

In Section 1.0, an overview of the Financial Analysis was provided and summarized in Table 1 for both the Retrieval and Disposal program and the TWRS project life cycle. Table 21 recaps the pre-Phase $1 \mathrm{~B}$ analysis budget requirements as discussed in previous sections.

Table 22 in this section shows a similar build-up of costs and the impact of proposed offsets and increases to the pre-Phase $1 \mathrm{~B}$ analysis.

Table 21. Pre-Phase 1B Analysis Budget Requirements Increases. (Dollars in millions)

\begin{tabular}{|l|r|r|}
\hline & \multicolumn{1}{|c|}{$\begin{array}{c}\text { Total } \\
\text { TWRS }\end{array}$} \\
\hline Updated Baseline changes to meet critical path (Section 4.1.2) & $\$ 159$ & $\$ 4954$ \\
Retrieval scope transfer shortfalls (Section 4.1.2) & 46 & \\
Allowance for risk to 80\% probability (Section 4.2) & 248 & \\
PBS compliance update (Section 4.6) & 5 & $\$ 5412$ \\
\hline Total & $\$ 458$ & $\$ 458$ \\
\hline Cost reduction opportunities (Section 4.7) & $\$(200)$ & $\$(200)$ \\
\hline
\end{tabular}

PBS $=$ Project Baseline Summary.

TWRS $=$ Tank Waste Remediation System.

The issues concerning the increased requirements in FY 1998/1999 and the recommended adjustments were discussed. The Phase 1B Program as recommended is achievable. Specific recommendations are as follows:

a. Adopt the revised TWRS project baseline as presented in Table 1 and Table 22.

b. Incorporate the $\$ 248.5$ million in allowances for risk into the baseline.

c. Develop detailed action plans tó realize the costs reduction opportunities.

d. Incorporate site indirect and benefits reduction rates into baseline.

e. Delay non-critical path scope which can be moved beyond FY 1999, as indicated.

f. Renegotiate the Tri-Party Agreement milestones associated with the current compliance unfunded list for FY 1998. 


\section{HNF-2017 Rev 0}

Further analysis not contained in the Financial Analysis document that will be performed oyer the next few weeks includes (1) analysis of Year 2000 and Work Management System incremental requirements, (2) development of probabilistic risks discussed in Sections 4.2 and 4.3 on a discrete annual basis, (3) analysis of rephased construction funding (FY 2000-2005) to accelerate AZ-101 and AW-103 retrieval systems and W-464/W-465 Immobilized Storage Disposal Projects to add schedule float, (4) final resource leveling, and (5) complete an updated integrated priority list. 


\begin{tabular}{|c|c|c|c|c|c|c|c|}
\hline FY: & 98 & 99 & 00 & 01 & 02 & $03-11$ & Total \\
\hline Budget Requirements (MYWP) & $\$ 332.6$ & $\$ 339.7$ & $\$ 353.2$ & $\$ 325.4$ & $\$ 322.7$ & $\$ 3,280.2$ & $\$ 4,953.8$ \\
\hline \multicolumn{8}{|l|}{ Existing Shortfall } \\
\hline - Compliance Unfunded (Section 4.6) & 31.0 & $(1.5)$ & $\cdots$ & $(9.6)$ & $(6.8)$ & $(13.1)$ & 0.0 \\
\hline - Vadose Zone Mapping/Logging (Section 4.6) & 4.0 & 4.0 & -.-- & --- &.-- &.-- & 8.0 \\
\hline - PBS Compliance Update (Section 4.6) & $\ldots$ & 3.9 & 4.4 & 0.6 & $(15.8)$ & 11.8 & 4.9 \\
\hline Budget Requirements (Pre-Phase 1B Analysis) & 367.6 & 346.1 & 357.6 & 316.4 & 300.1 & $3,278.9$ & $4,966.7$ \\
\hline \multicolumn{8}{|l|}{ Phase 1B Shortfallanalysis } \\
\hline - Updated $B / L$ to meet critical path (Section 4.1.2) & 8.5 & 18.1 & 21.1 & 3.3 & 6.3 & 101.7 & 159.0 \\
\hline - Retrieval Scope Transfer Shortfall (Section 4.1.4) & $(3.8)$ & $(5.1)$ & 2.9 & 20.1 & 13.9 & 20.0 & 46.0 \\
\hline S/T Phase 1B Shortfall Analysis & 4.7 & 13.0 & 22.0 & 23.4 & 20.2 & 121.7 & 205.0 \\
\hline Requirement@50\%.Certainty & 372.3 & 359.1 & 379.6 & 339.8 & 320.3 & $3,400.6$ & $5,171.7$ \\
\hline - Project Specific Risks (Cat. I \& II) (Section 4.2) & $=--$ & --.- & ---- & -... & 17.5 & 7.0 & 24.5 \\
\hline - Integrated Program Risks (Cat. III) (Section 4.3) & -.-- & $\cdots$ & 10.0 & 40.0 & 40.0 & 134.0 & 224.0 \\
\hline - Critical Path Analysis (Section 4.4 ) & $\underline{0.5}$ & 2.0 & 14.8 & (9.4) & $(12.6)$ & $(0.3)$ & $\underline{e .0}$ \\
\hline S/T Allowance for Risk & 0.5 & 7.0 & 24.8 & 30.6 & 44.9 & 140.7 & 248.5 \\
\hline Requirement@80\% Certainty & 372.8 & 366.1 & 404.4 & 370.4 & 365.2 & $3,541.3$ & $5,420,2$ \\
\hline \multicolumn{8}{|l|}{ Recommended Acțions } \\
\hline - Target Funding Analysis (Section 4.6) & $(5.2)$ & (4.3) & 9.5 & ---- & $\cdots$ & ---- & 0.0 \\
\hline - Vadose Zone Mapping/Logging (Section 4.6) & $(4.0)$ & $(4.0)$ & $\cdots$ & ---- & $\cdots$ & 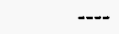 & $(8.0)$ \\
\hline - Compliance Unfunded Renegotiation (Section 4.6) & $(31.0)$ & 1.5 & ---- & 9.6 & 6.8 & 13.1 & 0.0 \\
\hline Updated Budget Requirements & $\$ 332.6$ & $\$ 359.3$ & $\$ 413.9$ & $\$ 380.0$ & $\$ 372.0$ & $\$ 3,554.4$ & $\$ 5,412.2$ \\
\hline Delta to MYWP & 0.0 & 19.6 & 60.7 & 54.6 & 49.3 & 274.2 & 458.4 \\
\hline ost $R e$ & $\cdots$ & $(10.0)$ & $(15.0)$ & $(15.0)$ & $(15.0)$ & $(145.0)$ & $(200.0)$ \\
\hline
\end{tabular}


HNF-2017 Rev 0

This page intentionally left blank. 
HNF-2017 Rev 0

\subsection{REFERENCES}

\section{Department of Energy Orders}

DOE Order 425.1, Startup and Restart of Nuclear Facilities, U.S. Department of Energy, Washington, D.C.

\section{Documents}

Baldwin, J. H., T. J. McLaughlin, R. D. Potter, and R. L. Treat, 1998, Tank Waste Remediation System Retrieval and Disposal Mission Key Enabling Assumptions, HNF-1945, Rev. 0, prepared by Lockheed Martin Hanford Corporation for Fluor Daniel Hanford, Inc., Richland, Washington.

Payne, M. A., P. J. Certa, J. O. Honeyman, J. G. Kristofzski, and W. T. Thompson, 1998, Management Assessment of Tank Waste Remediation System Contractor Readiness to Proceed With Phase 18 Privatization, HNF-2021, Rev. 0, prepared by Lockheed Martin Hanford Corporation for Fluor Daniel Hanford, Inc., Richland, Washington.

Swita, W. R., M. R. Lewis, and M. J. O'Neill, 1998, Tank Waste Remediation System Retrieval and Disposal Mission Initial Updated Baseline, HNF-1946, Rev. 0, prepared by Lockheed Martin Hanford Corporation for Fluor Daniel Hanford; Inc., Richland, Washington.

Zimmerman, B. D., 1998a, Tank Waste Remediation System Retrieval and Disposal Mission Risk List, Rev. 0, prepared by Lockheed Martin Hanford Corporation for Fluor Daniel Hanford, Inc., Richland, Washington.

Zimmerman, B. D., 1998b, Tank Waste Remediation System Risk Management Plan, HNF-SD-WM-PMP-018, Rev. 2, prepared by Lockheed Martin Hanford Corporation for Fluor Daniel Hanford, Inc., Richland, Washington. 
HNF-2017 Rev 0

This page intentionally left blank. 
HNF-2017 Rev 0

APPENDIX A

FINANCIAL DETAILS 
HNF-2017 Rev 0

This page intentionally left blank. 
HNF-2017 Rev 0

CONTENTS

A-1 Financial Analysis Risk Assessment Form/Details . . . . . . . . . . . . . A-1

A-2 Baseline Summary Detail by Year $\ldots \ldots \ldots \ldots \ldots \ldots \ldots \ldots \ldots \ldots \ldots \ldots \ldots \ldots \ldots$

A-3 Unfunded Phase 1B Baseline Cost Summary $\ldots \ldots \ldots \ldots \ldots \ldots \ldots \ldots \ldots$ A-5

A-4 Financial Analysis Summary Detail $\ldots \ldots \ldots \ldots \ldots \ldots \ldots \ldots \ldots \ldots \ldots \ldots \ldots \ldots$ 
HNF-2017 Rev 0

This page intentionally left blank. 
TBR Risk Assessment

TBR: 160.A52 Pretreat 241-AZ-101 (in Tank Sludge Washing)

Subactivity (WBS 8) Risk Assessment

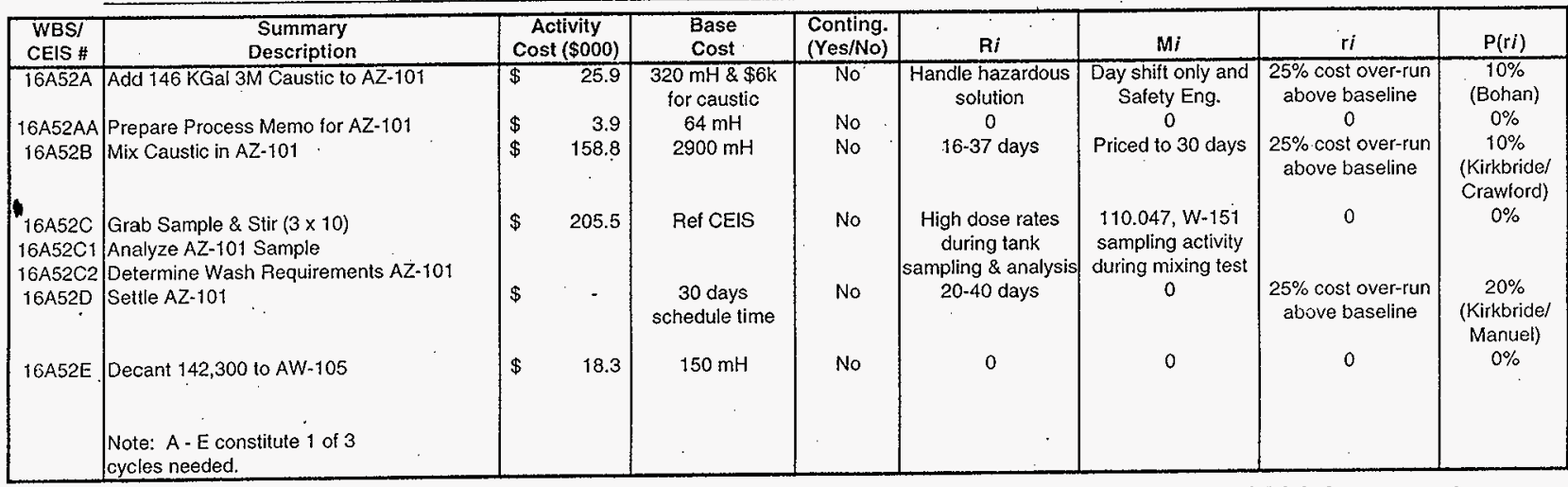

Level I (WBS 7) Risk Assessment

is

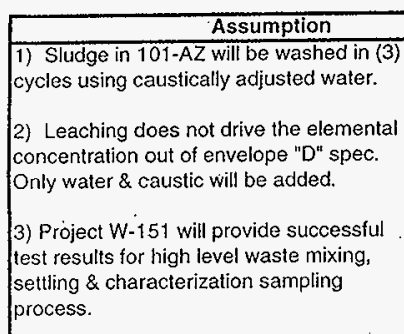
Baseline Risk

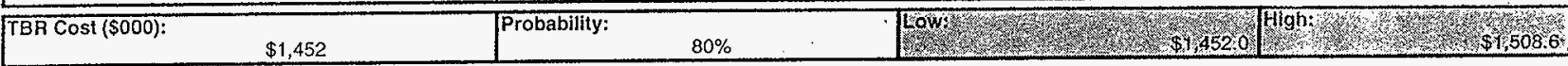




\begin{tabular}{|c|c|c|c|c|c|c|c|c|c|c|c|c|c|}
\hline $\begin{array}{c}\text { Actrity } \\
\text { Prime ID } \\
\end{array}$ & $\begin{array}{l}\text { Status ... } \\
> \\
\text { Prime or } \\
\text { Repeard }\end{array}$ & $\begin{array}{c}\text { P. C. } \\
\text { ist } \\
\text { Unit } \\
\text { Equi } \\
\text { or } \\
\text { simi } \\
\end{array}$ & 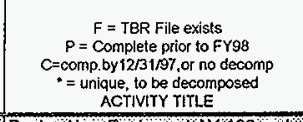 & $\begin{array}{l}\text { For LAW } \\
\text { No Sht } 7 \\
0=\text { Sht } 10+ \\
=\text { Sht } 11 \ldots+.> \\
\text { OWNER }\end{array}$ & $\begin{array}{l}\text { Min cost } \\
(\$ K)\end{array}$ & $\begin{array}{c}\operatorname{Max} \cos t \\
(\$ \mathrm{~K})\end{array}$ & $\begin{array}{c}\text { Budget } \\
\text { (\$K) }\end{array}$ & $\begin{array}{c}\text { Conf } \\
(\%)\end{array}$ & & Quad IIIUI & $\begin{array}{c}\text { Cost } \\
\text { Account }\end{array}$ & Prob Dist & Comment \\
\hline 050.020 & 0.50 .020 & U. & 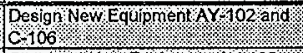 & $w=320$ & $5 \times 668$ & 8 & S. $852 \%$ & $50 \%$ & & & 11310106 & 1823,69 & \\
\hline $050.030^{\circ}$ & $050.030 \%$ & 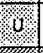 & 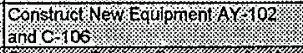 & $W_{320}$ & (1. $5.528: 1$ & $8,8.242,3$ & 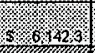 & $90 \%$ & & & 11310106 & & \\
\hline$(2 x 3.62$ & (3) & 新衫 & 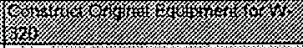 & Westis & & & & & & & 11310106 & & \\
\hline 050.045 . & 050.045 & 80 & Desiguvequipinent support tor W. 320 & Wis20. & $3 ., 7,55.3$ & S. $.37 \%$ & (5.2.2.120 & 50\% & & & 11310106 & 230.8 & \\
\hline 050.050 & 050.050 & U. & 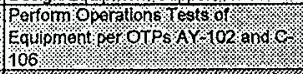 & $w=320$ & (. . & $8.82 .8 \%$ & S. $=7,2: 0$ & $90 \%$ & & & 11310106 & $1823.2 \times$ & \\
\hline 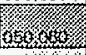 & 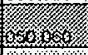 & 1. & Hox & & & & & & & & & & \\
\hline 050.070 \% & 050.070 & 10 & 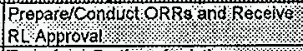 & & 201 & 9001 & $800 . ;:$ & $80 \%$ & & & 11310106 & $806: 3 \%$ & \\
\hline 050.080 & 050.080 & U. & 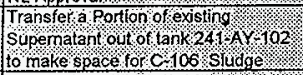 & & (6: & & & $90 \%$ & & & 11310112 & 29.10 & \\
\hline 0.050 .085 & 050.085 & Uू & DOE-RLORR for $W-320$ : & DOE:RL & & & & & & $x$ & & & \\
\hline 050.090 & 050.090 & U. & Sluice $241-106$ into $241-A Y 102$, & Ops. & 5.2373 & $8,2,900.0$ & $8 \% 2,4080$ & 95\%: & & & 11310112 & 2623.0 .00 & \\
\hline 050.100 & 050.100 & पul & Design Additional Egujpiment $/$. & W:320 & S & S. 3959 & S. $185: 0$ & $90 \%$ & & & 11310106 & 2488 & \\
\hline 05011.10 & $050: 110$ & 0 & Construct Addifional Equiponent & $W \div 320$ & $5 \times 658.8$ & S., 12320 & $S=7320$ & 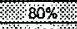 & & & 11310106 & 6 843 & \\
\hline 050.120 & 050,120 & $\frac{U}{4}$ & $\begin{array}{l}\text { Test Add dlionial Equípinent } \\
\text { WRSS Process control }(1: 320)\end{array}$ & $\frac{W-320}{W=320}$ & $\frac{3.55,0}{S .1,9532}$ & $8.55,0$ & $\frac{5 . \% 50}{S \times 2 \times 480}$ & $\frac{100 \%}{\% 99 \%}$ & & & $\frac{11310106}{11310106}$ & $\frac{2450}{2443}$ & \\
\hline 16.0. & 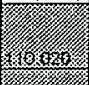 & 䋞, & (1) & & & & & & & & 年 & & \\
\hline 3ink & 3nons & 终 & (6) & & & & & & & & & 3 & \\
\hline 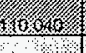 & 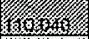 & 4 & o & 20 & & & & & & & & & \\
\hline 110.045 & 110.045 & 4 & $\begin{array}{l}\text { Revise/lssue Mixer Rump Test/ } \\
\text { Plansiprocedures }\end{array}$ & Retrieval & $3 . .28$ & 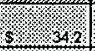 & 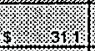 & $98 \%$ & & & $1131014 \mathrm{P}$ & 3. & \\
\hline 110.047 & 110.047 & $\%$ & $\begin{array}{l}\text { Porforni Mixerpump Testsamoling } \\
\text { and Analysis }\end{array}$ & Charn & 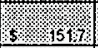 & 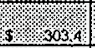 & $1.252: 8$ & $.05 \%$ & & & 11310102 & 2339 & \\
\hline 110.050 & 110.050 & U. & $\begin{array}{l}\text { Conduct leMHCG Readiness } \\
\text { Assossment }\end{array}$ & Retrieval & 8.9 .1683 & 3.0 .374 .0 & $08 \%: 0$ & $00 \%$ & & & $1131014 E$ & . & \\
\hline 110.060 & 110,060 & $\mathrm{U}$ & Receive:DOE Approval to Operate & DOERL & 10 & 10 & . & 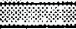 & & $x$ & & 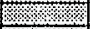 & \\
\hline 110.070 & 110.070 & 4 & $\begin{array}{l}\text { Perform Mixé Pump Test" } 241 \text { AZ } \\
\text { 101 W } 151)\end{array}$ & Retrivall & s. & S. 246.4 & S. & $80 \%$ & & & $1131014 E$ & $214: 4$ & \\
\hline 110.070 & 110.070 & 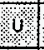 & 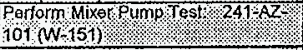 & Retrieval & 3.2 .2$. & 0.0 .5 & & $800 \%$ & 2 & & $1131014 \mathrm{P}$ & 80.20 & \\
\hline 110.090 & $110,090:$ & U: & Prepare Mixér Tést:Report: $(W=151)$. & Rétriéval & $9.88 \%$ & 5.12727 & $5 \times 2$ & 385\% & & & $1131014 \mathrm{P}$ & 1017? & \\
\hline 120.830 & 120.830 & 19 & Revise W.21 1 rDC for Staging Tank & Retrieval, & & & & & & & & ! & Completed \\
\hline 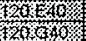 & $y_{2}$ & 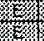 & 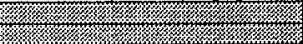 & 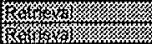 & 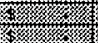 & $\frac{1}{3 x}$ & & 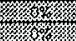 & 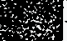 & & $\frac{10}{10}$ & 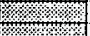 & \\
\hline
\end{tabular}




\begin{tabular}{|c|c|c|c|c|c|c|c|c|c|c|c|c|}
\hline rime l.D. & & $\begin{array}{l}\text { LLWI } \\
\text { HLWI } \\
\text { S\&D/ } \\
\text { INF }\end{array}$ & $\begin{array}{l}\text { P. C, } \\
\text { 1st. } \\
\text { Uni, } \\
\text { Equi } \\
\text { or } \\
\text { Simi } \\
\end{array}$ & Activity Tittle & Owner & RISK OESCRIPTION & ASSUMPTION & MIN & $\max$ & NOM & 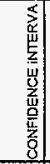 & REPEATS \\
\hline 50.020 & 11310106 & HLW & u & $\begin{array}{l}\text { Design Now Equipment AY-102 and } \\
\text { C-106 }\end{array}$ & $W-320$ & NA & $\begin{array}{l}\text { Projectprogram management assumed until } \\
\text { completion and final analysis of all stuicing } \\
\text { operations in Frg9 }\end{array}$ & & & & & \\
\hline$\theta$ & & & & & & $\begin{array}{l}\text { Only one of the four pumps has to fail to stop } \\
\text { slutcing operations. Eloctrical oquipment and } \\
\text { polymeric hosos are exposed to very high } \\
\text { radaition levels and ilgh temperatures }\end{array}$ & $\begin{array}{l}\text { No pump tailures occur that require equipmont } \\
\text { romoval, ropair, replacement prior to completion } \\
\text { of sluicing }\end{array}$ & 5708.8 & $\$ 3,852.0$ & $\mathbf{S 8 5 2 . 0}$ & $50 \%$ & \\
\hline 50.030 & 11310106 & HLW & $\mathrm{U}$ & $\begin{array}{l}\text { Construct New Equipment AY-102 } \\
\text { and C-106 }\end{array}$ & W-320 & $\begin{array}{l}\text { Somo uncortainly whether the tank annulus } \\
\text { bottom cooling channeis are blocked, and } \\
\text { whother tho high vacuum annulus blocking } \\
\text { modification will perform as intonded. }\end{array}$ & $\begin{array}{l}\text { Vont systoms, instrument systerns, and pit } \\
\text { jumpors for Ay-102 and C-106 can be } \\
\text { constructed as designed }\end{array}$ & $\$ 5,528.1$ & $\$ 0,242.3$ & $\$ 6,142.3$ & $20 \% 6$ & \\
\hline 50.045 & 11310106 & HLW & $\mathrm{U}$ & DesignJEquipment Support for W-320 & W-320 & $\begin{array}{l}\text { Procodonts by other projocts, off-notmal } \\
\text { occurronces, and other now roqulrements aro } \\
\text { always a possibitity. }\end{array}$ & $\begin{array}{l}\text { Includes current requitements for configuration } \\
\text { control, operating grocedures and training }\end{array}$ & $\$ 1,095.3$ & $\$ 2,7170$ & $\$ 2,217.0$ & $90 \%$ & \\
\hline 50.050 & 11310106 & HLW & $u$ & $\begin{array}{l}\text { Perform Operations Tests of } \\
\text { Equipment per OTPs AY- } 102 \text { and C- } \\
106\end{array}$ & $W-320$ & $\begin{array}{l}\text { Random equipment failures can still occur. Will } \\
\text { nave most spare parts to repair most equlpment if } \\
\text { nogodod }\end{array}$ & $\begin{array}{l}\text { All equipment performs as intended, based on } \\
\text { successful, comprehensive AIP's prior to OIP's }\end{array}$ & $\$ 738.2$ & 5827.0 & $\$ 777.0$ & $90 \%$ & \\
\hline 50.070 & 11310106 & HLW & $u$ & $\begin{array}{l}\text { Prepare/Conduct ORRs and Recoive } \\
\text { RL Approval }\end{array}$ & $\begin{array}{l}\text { W-320/ } \\
\text { Ops }\end{array}$ & $\begin{array}{l}\text { Awrays a modest risk that indopendent roviowers } \\
\text { will identify deficioncios or tiffering interprotations } \\
\text { of requilements loading to delays and costly } \\
\text { corroctive actions }\end{array}$ & $\begin{array}{l}\text { Realistic durations of 3-tier ORR based on } \\
\text { recont history. Time allocated for modest } \\
\text { comective actions }\end{array}$ & 5720,1 & 5000.1 & $\$ 800.1$ & $90 \%$ & \\
\hline 50.080 & 11310112 & HLW & $u$ & $\begin{array}{l}\text { Transfer a Portion of existing } \\
\text { Supernatant out of tank } 241-\mathrm{AY}-102 \\
\text { to make space for C-106 Sludge }\end{array}$ & Oeps & $\begin{array}{l}\text { Prepare Transfer Proced ure AY-102 to AP106 and } \\
\text { Transter } 36 \mathrm{~K} \text { galion from AYr } 102 \text { to AP-106 }\end{array}$ & Nom & $\$ 14.9$ & $\$ 43.3$ & $\$ 29.1$ & $\infty 0 \%$ & \\
\hline 50.085 & & & $\bar{U}$ & DOE-RL ORR for W-320 & DOE-RL & ORR will tako 45 calandar days, program risk & ORR will complete in 30 Calendar Days & & & & & \\
\hline 50.090 & 11310112 & HLW & $u$ & Sluice 241-C-106 into 241-AY-102 & Ops & $\begin{array}{l}\text { Lines could plug, waste may form, leaks may } \\
\text { devolop, high rad levels may oxist, C-106 sludgo } \\
\text { may bo harder/stronger than planned }\end{array}$ & $\begin{array}{l}\text { Sluicing goos according to pian over } 12 \text { month } \\
\text { period. in } 80^{\prime} \text { s. } 70^{\prime \prime} 13 \text { tanks were sluiced with } \\
\text { similar equipmont }\end{array}$ & $\$ 2.373 .1$ & $\$ 2,998.0$ & $\$ 2.498 .0$ & $95 \%$ & \\
\hline 50.100 & 11310106 & $H L W$ & $U$ & Dosign Additional Equipment & $W-320$ & $\begin{array}{l}\text { Ever worse assumptions could ros ult, duo to } \\
\text { poorly characterized sludge in C } 106 \text {. If } \\
\text { necossary, the requited } 30 \text { osogreo F subcooling } \\
\text { margin in the TSR's could probably be teduced } \\
\text { based on the largo number of tomp instruments } \\
\text { lon AY-102 }\end{array}$ & $\begin{array}{l}\text { Contingency for installing a safety class } \\
\text { blower/chillet on AY-102 for additional șludge } \\
\text { cooling }\end{array}$ & & & & & \\
\hline & 11310106 & HLW & & 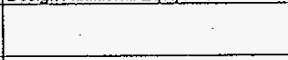 & & $\begin{array}{l}\text { Alternativo, the W-211 rotrioval pumps could bo } \\
\text { expedited for AY-102 to either mix and cool tho } \\
\text { waste or to retiove wasto }\end{array}$ & & 5168.5 & $\$ 395.0$ & $\$ 185.0$ & $\$ 0 \%$ & \\
\hline 50.110 & 11310106 & HLW & $\mathbf{u}$ & Construct Additional Equipment & $W-320$ & $\begin{array}{l}\text { Condition of existing duct work is uncortain. Fow } \\
\text { vendors available for saloty class chillers. } \\
\text { Contingency has boon included, but not enough }\end{array}$ & $\begin{array}{l}\text { Standard constructions ostimate for safoty class } \\
\text { vent equigment. }\end{array}$ & $\$ 058.8$ & $\$ 1,2320$ & 5732.0 & $80 \%$ & \\
\hline 50.120 & 11310106 & HLW & u & Test Additional Equipment & $w-320$ & $\begin{array}{l}\text { Always a risk of poor vendor performance that will } \\
\text { not show up until testing in field }\end{array}$ & Estimate based on a recent testing history & $\mathbf{S 5 5 . 0}$ & 5550 & $\$ 55.0$ & $100 \%$ & \\
\hline 50.130 & 11310106 & HLW & $\mathbf{u}$ & WRSS Procoss Control (W-320) & $W-320$ & $\begin{array}{l}\text { Always a risk of Independent reviowers identifying } \\
\text { new issues that will require more analysis. }\end{array}$ & $\begin{array}{l}\text { Includes procoss control plan, themal modeling, } \\
\text { saloty analysis, and technical reviows. Thorough } \\
\text { PHMC reviow will awoid changes by external } \\
\text { reviowers }\end{array}$ & $51,933.2$ & $\$ 2,348,0$ & $\$ 2,148.0$ & $99 \%$ & \\
\hline 10,045 & $1131014 P$ & HLW & $\mathbf{U}$ & $\begin{array}{l}\text { Revise/lssue Mixer Pump Test } \\
\text { Plans/Procedures. }\end{array}$ & Retrioval & ten- & D. & $\$ 28.0$ & $\$ 34.2$ & $\$ 31.1$ & $98 \%$ & \\
\hline 10.047 & 11310102 & HLW & $u$ & $\begin{array}{l}\text { Perform Mixer Pump Test Sampling } \\
\text { and Analysis }\end{array}$ & Charzn & NuA & $\begin{array}{l}\text { Sample will bo } 5 \text { bottles from } 5 \text { depths from } \\
\text { slingle riser }\end{array}$ & & & & & \\
\hline & & & & & & N/A & $\begin{array}{l}\text { Samples will be tested for envolope and particle } \\
\text { size }\end{array}$ & $\$ 151.7$ & 5303.4 & $\$ 252.8$ & $\$ 8 \%$ & 1. \\
\hline 10.050 & $1131014 \mathrm{E}$ & HLW & $\mathbf{U}$ & $\begin{array}{l}\text { Conduct LMHC Readiness } \\
\text { Assessment }\end{array}$ & Retrieval & $\begin{array}{l}\text { An Operational Readiness Review will be } \\
\text { required to bo portomod resulting in cost and } \\
\text { schodula orerrins. Cost of an ORR will be twice } \\
\text { the cost of the assessment }\end{array}$ & $\begin{array}{l}\text { Roadiness teissue will consist of a Readiness } \\
\text { Assessment }\end{array}$ & $\$ 168.3$ & 5374,0 & $\$ 187.0$ & 900 & \\
\hline 10.060 & & & $u$ & Receive DOE Approval to Operate & DOE-RL & $\begin{array}{l}\text { The RL readiness essessment will take } 45 \text { days } \\
\text { to complete }\end{array}$ & $\begin{array}{l}\text { The RL readiness assessment will take } 4 \\
\text { calendar weeks to complote }\end{array}$ & & & & & \\
\hline
\end{tabular}




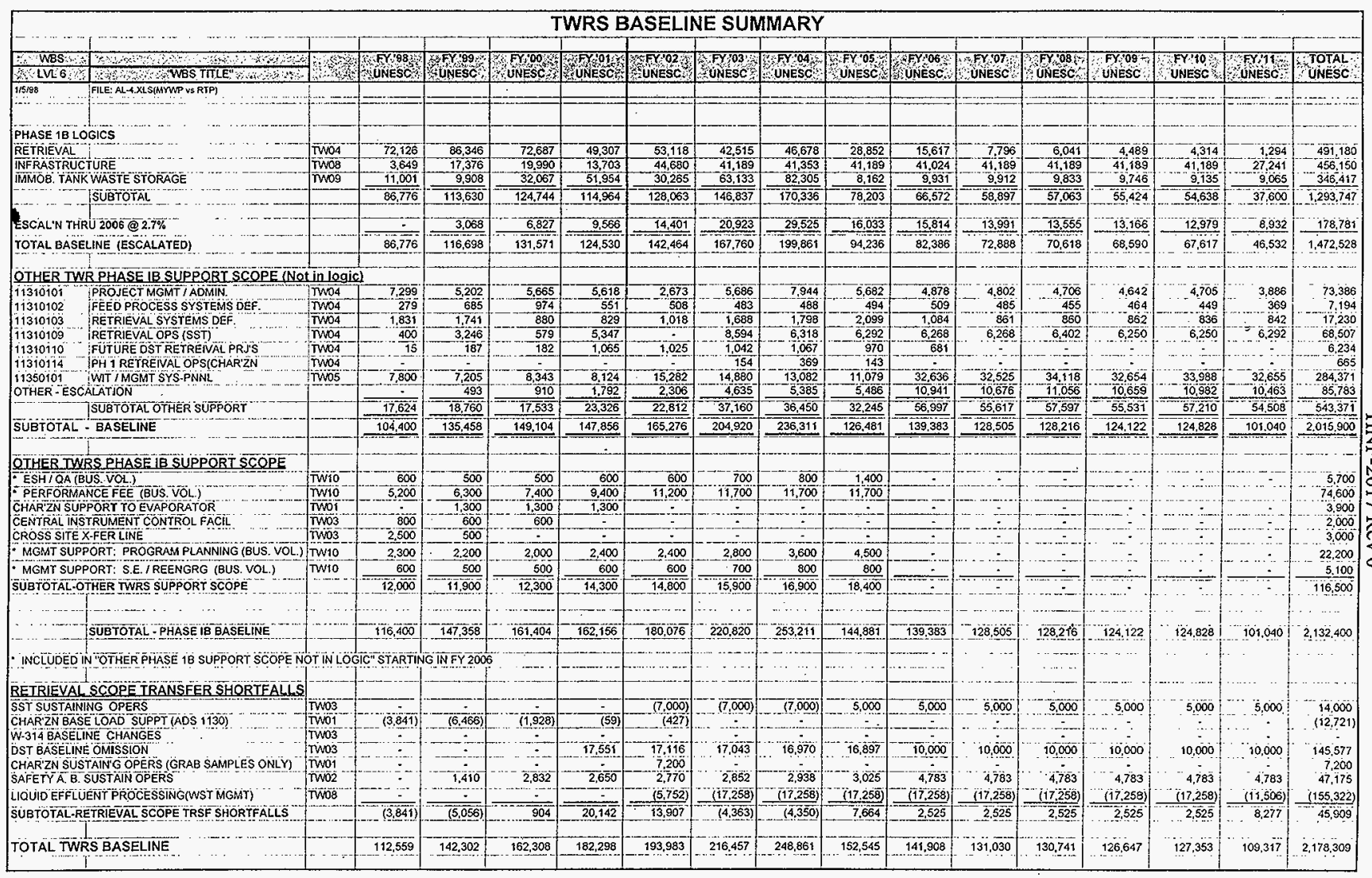




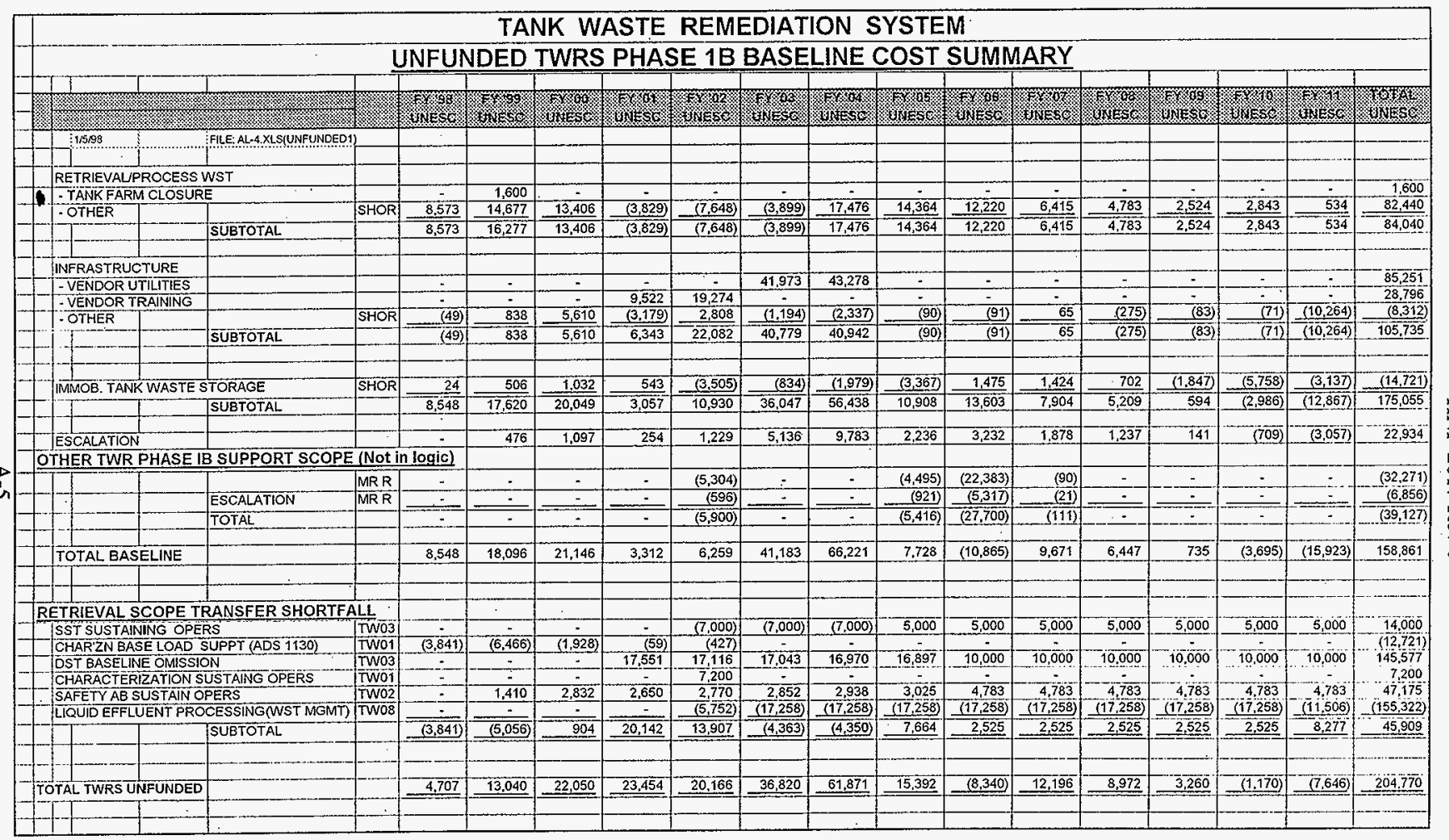




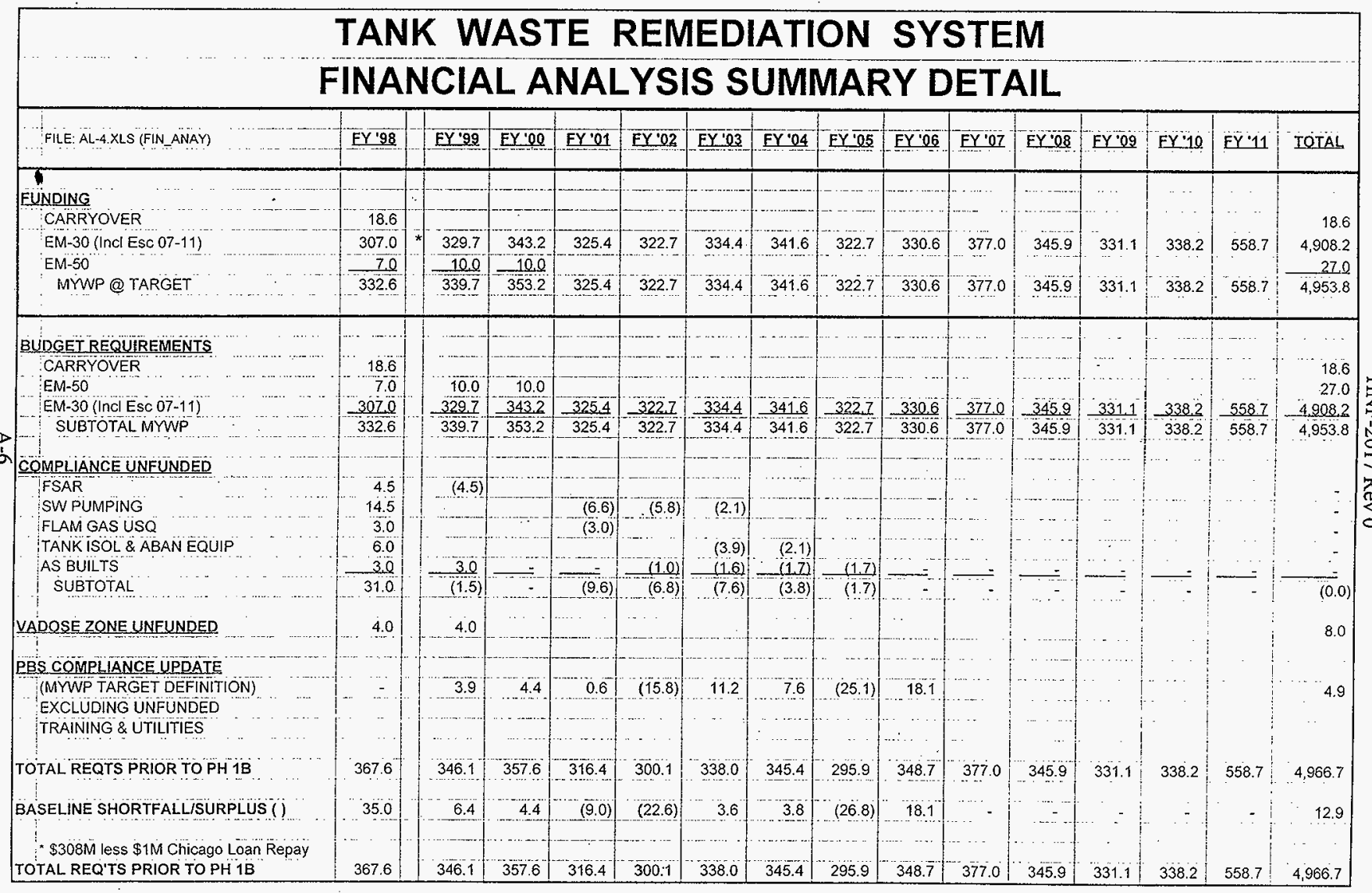




\begin{tabular}{|c|c|c|c|c|c|c|c|c|c|c|c|c|c|c|c|}
\hline FILE AL-4 XLS (FIN_ANAY) & EY98 & FY99 & EY'OO & FY.01 & FY'02 & FY'03 & EY'04 & $E Y^{\prime} 05$ & EY.06 & EY 07 & FYOB & 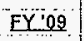 & FY'10 & EY:11 & TOTAL \\
\hline$\pi$ & & & & & & & & & & & & & & & \\
\hline PHASE $1 B$ ANALYSIS & & & 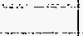 & & & & & & & & & ......... & & & - \\
\hline CHANGES TO MYWP (Sec 2.2.1) & & & & & & 42.0 & 43.3 & & & & & & & & 85.3 \\
\hline Utilities & & & & 9.5 & 19.3 & & & & & & & & & & 28.8 \\
\hline - Vendor Oper. Training & & & & & (5.9) & & & (5.4) & (27.7) & $(0.1)$ & & & & & (39.1) \\
\hline - Retrieval Reserves - Ph 1B New Est & 8.5 & $\frac{18.1}{1.18}$ & 211 & $(6.2)$ & $(7.1)$ & $(0.8)$ & 22.9 & 13,1 & 169 & 98 & 6.4 & 07 & $-(3.7)$ & $-(15,7)$ & 84.0 \\
\hline SUBTOTAL & 8.5 & 18.1 & 21.1 & 3.3 & 6.3 & 41.2 & 66.2 & 7.7 & $(10.8)$ & 9.7 & 6.4 & 0.7 & $(3.7)$ & $(15.7)$ & 159.0 \\
\hline RETRIEVAL SCOPE TRANSFER SHORTF & ÁLL $(\mathrm{Sec}$ & 2.1) & & & & & & & & & & & & & $\cdot$ \\
\hline - SsT Operns Transfer & & & & & $(7.0)$ & $(7.0)$ & $(7.0)$ & 5.0 & 5.0 & 5.0 & 5.0 & 5.0 & 5.0 & 5.0 & $14.0^{-1}$ \\
\hline - DST Operns Tramsfer & & & & 17.5 & 17.1 & 17.0 & 17.0 & 17.0 & 10.0 & 10.0 & 100 & $10.0^{\circ}$ & 100 & 10.0 & 145.6 \\
\hline - Characterization Disp'si Suppt In Baseli & $(3.8)$ & $(6.5)$ & $(1.9)$ & $(0.1)$ & $(0.4)$ & & & & & & & & & & $(12.7)$ \\
\hline - Safety Auth Basis Transfer & (n) & 1.4 & 2.8 & 2.7 & 2.8 & 28 & 29 & 3.0 & 4.8 & 4.8 & 4.8 & 48 & 4.8 & 4.8 & 47.2 \\
\hline - Characterization Transfer & - & 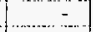 & 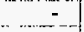 & $=-$ & 7.2 & & -1 & & $=$ & - & $=$ & - & $\therefore$ & $\therefore$ & 7.2 \\
\hline - Liquid Eff. Processing & - & $\frac{-}{1-\ldots}$ & 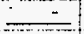 & & $(5.8)$ & $(173)$ & $(17.2)$ & $(17.3)$ & $(17.2)$ & $(17.3)$ & $(17.2)$ & $(17.3)$ & $(17.2)$ & $(11.5)$ & $(155.3)$ \\
\hline SUBTOTAL & $(3.8)$ & (5.1) & 0.9 & 20.1 & 13.9 & $(4.5)$ & $(4.3)$ & 7.7 & 2.6 & 2.5 & 2.6 & 2.5 & 2.6 & 8.3 & 46.0 \\
\hline TOTAL PHASE 1B BASELINE & 372.3 & 359.1 & 379.6 & 339.8 & 320.3 & 374.7 & 407.3 & 311.3 & 340.5 & 389.2 & 354.9 & 334.3 & 337.1 & 551.3 & $5,171.7$ \\
\hline$\cdots$ & & & $(\cdots \cdots \cdots \cdots$ & a......... & 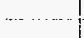 & $\ldots+$. & & $\ldots$ & $\ldots$ & & & & & & . \\
\hline PHASE IB RISK ANALYSIS $(S e c 2.22)$ & & & & .............. & & & & & & & & & & & $\therefore$ \\
\hline HLW & & & & & 1.5 & & & & & & & & & & 1.5 \\
\hline - LAW & & & & & 40 & & & & & & & & & & 4.0 \\
\hline - Immob Wste (S\&D) & & & & & 11.0 & & & & & & & & & & 11.0 \\
\hline - Infrastructure & - & $\frac{-}{-1}$ & $\frac{-}{-\cdots}$ & - & 1.0 & 1.0 & 1.0 & 1.0 & 1.0 & 1.0 & 1.0 & 1.0 & & & 8.0 \\
\hline SUBTOTAL & - & $\ldots=$ & & - & 17.5 & 10 & 1.0 & 1.0 & 1.0 & 1.0 & 1.0 & 1.0 & & & 24.5 \\
\hline PRÓGRAMMATIC RISK (Sec 2.2.3) & $\ldots$ & & 10.0 & 40.0 & 400 & 9.0 & 50 & 40.0 & 20.0 & 20.0 & 200 & 20.0 & & & $2240^{\circ}$ \\
\hline PHASE 1B ANALYSIS (Cont) & & & & & & &.$\ldots \ldots$. & $\ldots$ & & & & & & & $\because$ \\
\hline
\end{tabular}




\section{TANK WASTE REMEDIATION SYSTEM FINANCIAL ANALYSIS SUMMARY DETAIL}

\begin{tabular}{|c|c|c|c|c|c|c|c|c|c|c|c|c|c|c|c|}
\hline FILE: AL-4,XLS (FIN_ANAY) & EY.98. & EY 99 & EY'QQ & EY'01. & FY'O2 & EY.03 & EY.04 & EY.05 & EY06 & $E Y 07$ & $E Y^{\prime} O 8$ & EYOQ & $E Y 10$ & EY11 & TOTAL \\
\hline 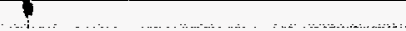 & & & & & & & & & & & & & & & - \\
\hline LIMITED VADOSE BORE/LG & $(4.0)$ & $(4.0)$ & & & -1 & $\cdots$ & & $\cdots \cdots \cdots=$ & 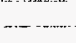 & …… & (........... & & & & (8.0) \\
\hline RECOMM FUNDISCOPE PROFILE & 332.6 & 349.3 & 398.9 & 365.0 & 357.0 & 377.0 & 402.1 & 338.0 & 345.5 & 394.2 & 359.9 & 338.3 & 320.1 & 534.3 & $5,212.2$ \\
\hline NET EXPOSURE TO TARGET & - & 9.6 & 45.7 & 39.6 & 34.3 & 42.6 & 60.5 & 15.3 & 14.9 & 17.2 & 14.0 & 7.2 & $(18.1)$ & (24.4) & 258.4 \\
\hline
\end{tabular}


HNF-2017 Rev 0

This page intentionally left blank. 
HNF-2017 Rev 0

APPENDIX B

FINANCIAL DETAILS 
HNF-2017 Rev 0

This page intentionally left blank. 


\section{HNF-2017 Rev 0 \\ CONTENTS}

B-1 High-Level Waste Batches 1 and 2 Primavera Critical Path Schedules . . . . . . . B-1

B-2 Low-Activity Waste Batch 1 Primavera Critical Path Schedule $\ldots \ldots \ldots \ldots \ldots \ldots$ B-5

B-3 Immobilized Waste Primavera Critical Path Schedule $\ldots \ldots \ldots \ldots \ldots \ldots \ldots$ B-9

B-4 Infrastructure Primavera Critical Path Schedule $\ldots \ldots \ldots \ldots \ldots \ldots \ldots \ldots \ldots$ B-14 


\section{HNF-2017 Rev 0}

This page intentionally left blank. 


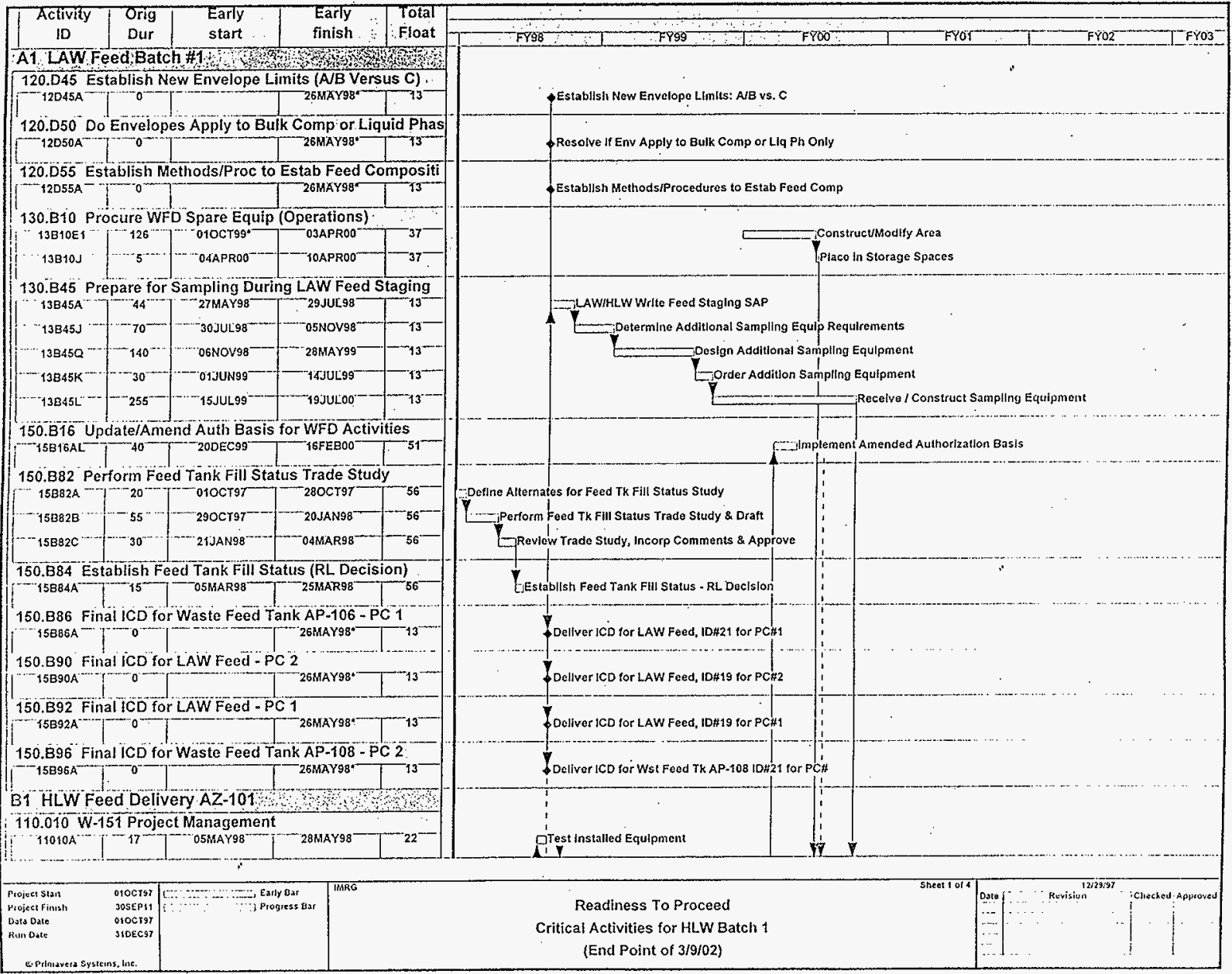




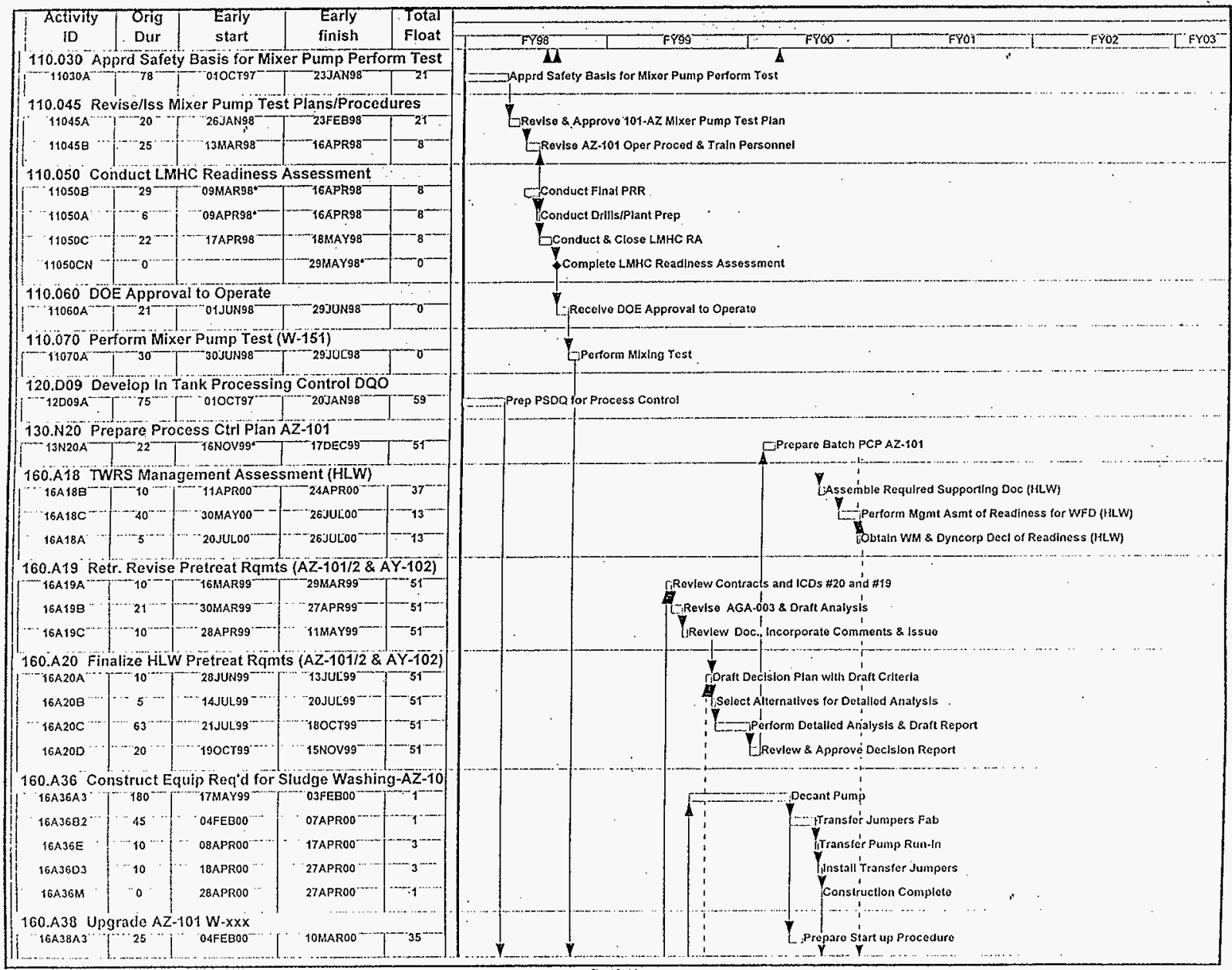




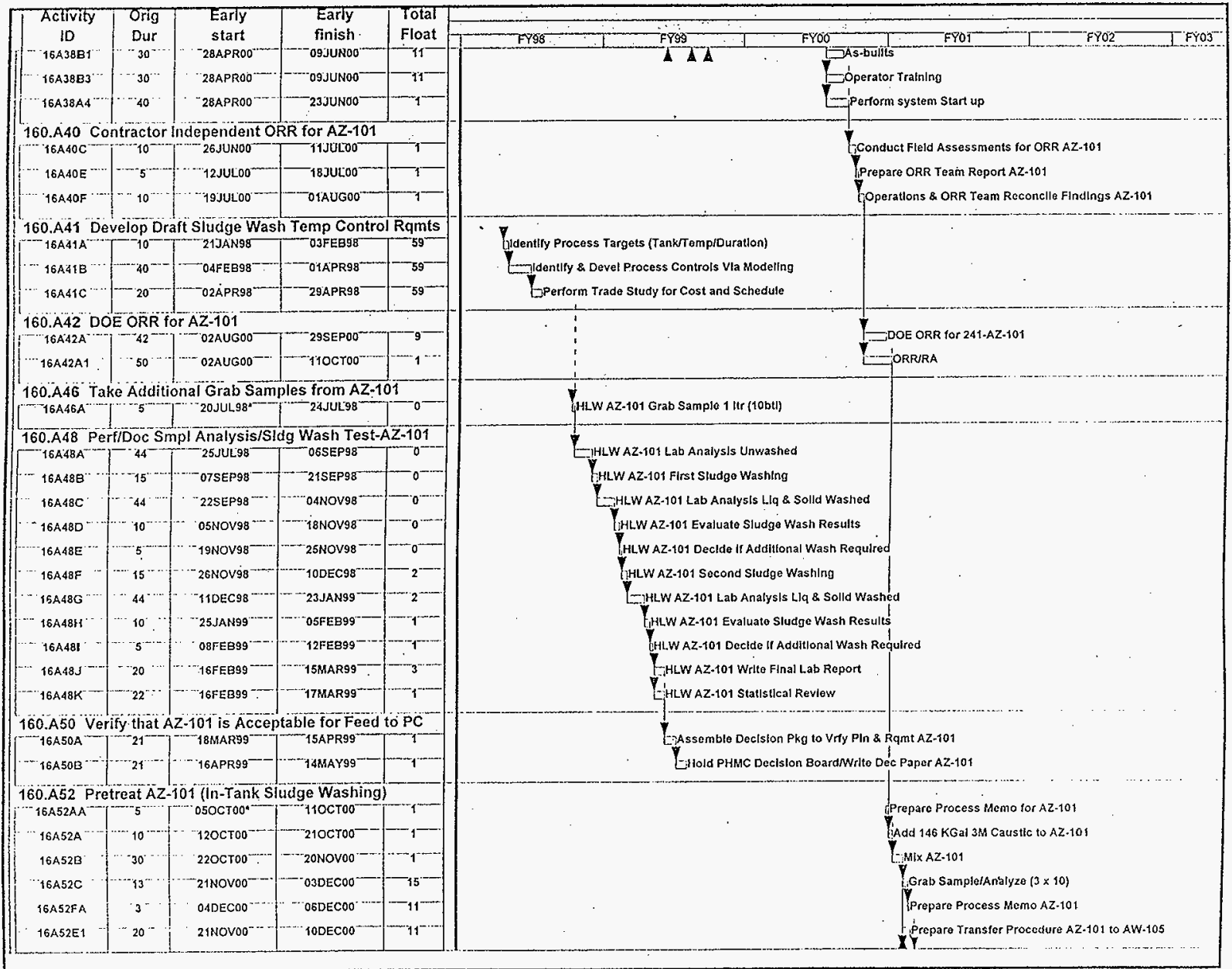




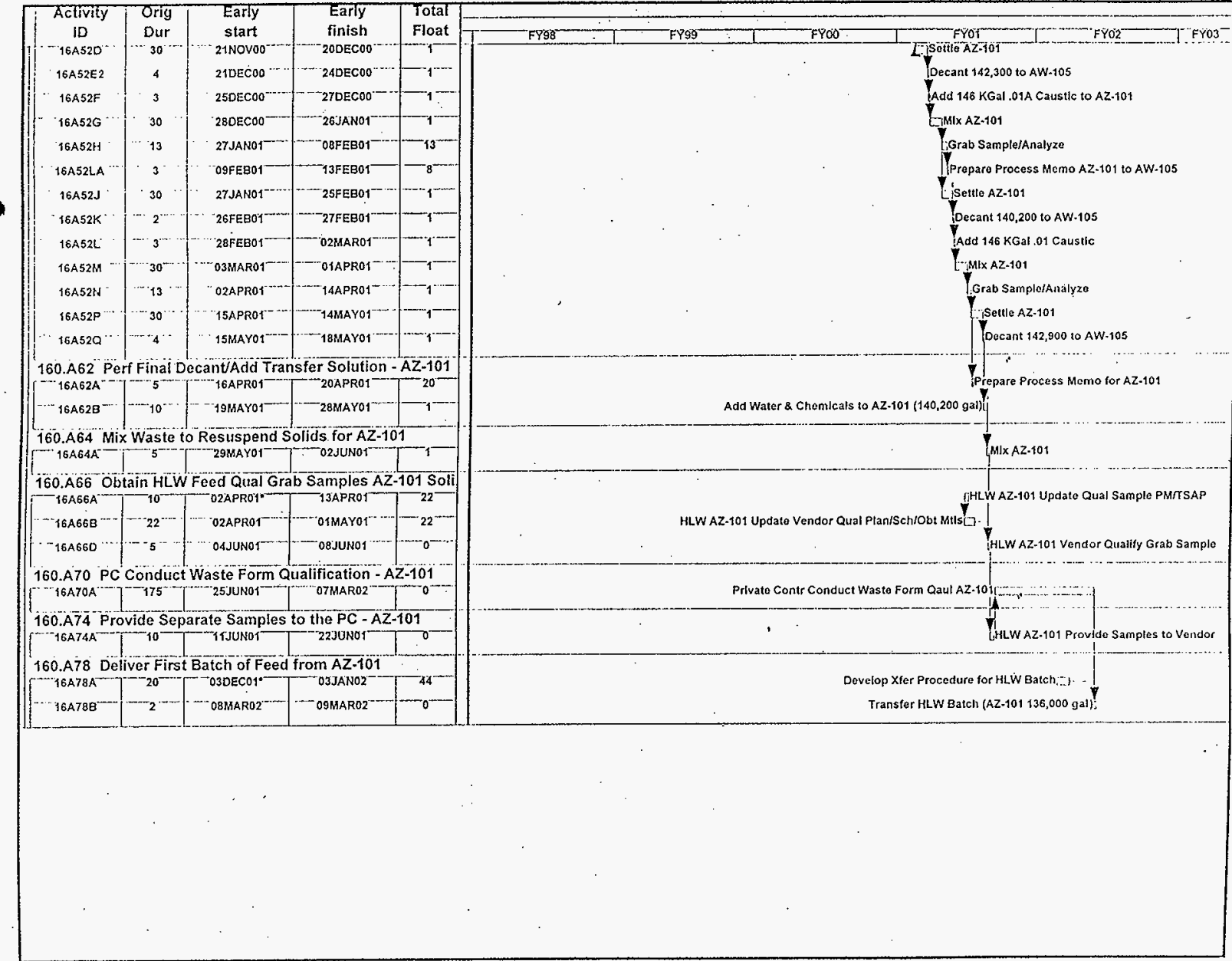




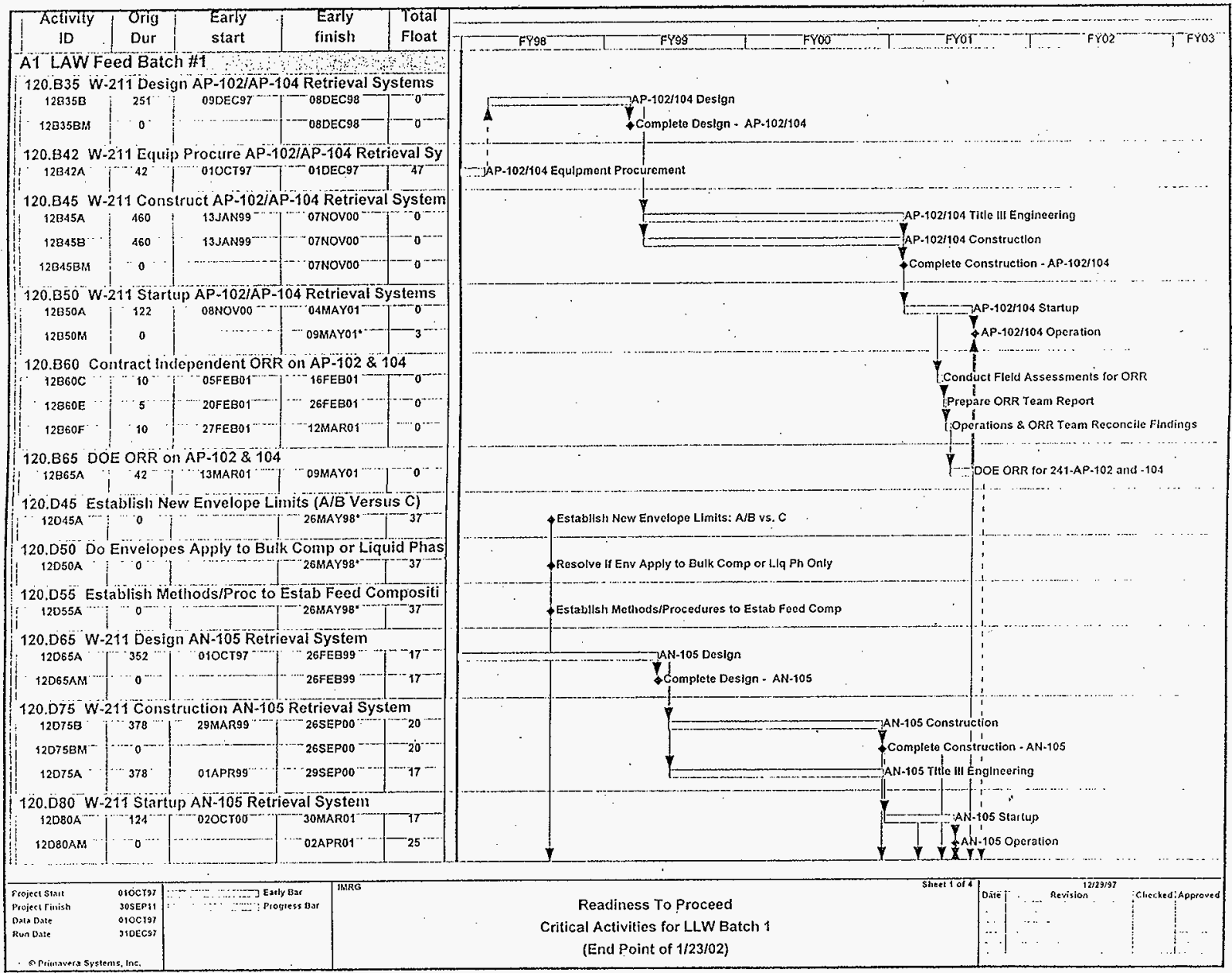




\begin{tabular}{|c|c|c|c|c|c|}
\hline Activity & Orig & Early & Early & Total & 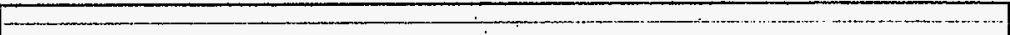 \\
\hline ID & Dur & start & finish & Float & 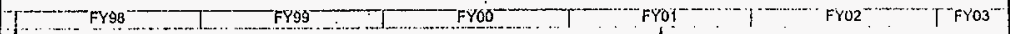 \\
\hline \multicolumn{5}{|c|}{ 120.D90 Contract Independent ORR AN-105 } & 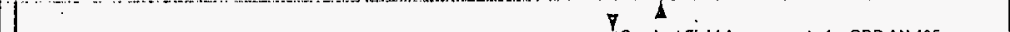 \\
\hline$\cdots 12090 \mathrm{C}$ & 10 & $" 270 E C 00-\cdots$ & TOJANOT & ${ }^{-4} 17^{--}$ & eld Assossments for ORR AN-105 \\
\hline $12090 \mathrm{E}$ & 5 & 11JAN01 -- & 17JANO1-- & $17 \cdots$ & IR Tenm Report AN-105 \\
\hline $12090 \mathrm{~F}$ & 10 & 18JANO' & 31JANO1 & $-17^{--}$ & Loperations \& ORR Téam Reconcile Findings $A N-10$ s \\
\hline \multicolumn{5}{|c|}{ 120.D95 DOE ORR AN-105 } & \multirow{4}{*}{ DOE ORR for $241 \cdot A N-105$} \\
\hline $12095 \AA$ & ${ }^{\prime 4}{ }^{2}$ & O1FEBO1 & O2APRO1 & 17 & \\
\hline \multicolumn{5}{|c|}{$130 . B 25$ Degas AN-105 } & \\
\hline 138258 & $\because 60$ & O3APR01" & $01 \mathrm{JUNOS}$ & -35 & \\
\hline \multicolumn{5}{|c|}{ 130.B30 Mob/Retr Wst in AN-105/Rec Feed in AP-102jAP-1 } & \multirow{11}{*}{$\begin{array}{l}\text { Prep Process Memo to Operate Mixer Pumps AN-105 } \\
\text { Add Dlluent (-25 KGal) Decant Pump Reclre AN-105. } \\
\text { Perform Grab Sampling \& Analysis of AN-105: }\end{array}$} \\
\hline 13E330E & 5 & 25APROT $\cdots$ & O1MAYO1 & 59 & \\
\hline $13830 \wedge$ & 2 & o7 JULO' & OBJULO1 & 0 & \\
\hline $13 B 3082$ & 6 & ogJuLO & 14.JULOI - & 0 & \\
\hline $13830 \mathrm{C} 2$ & 6 & 15JULO1 ${ }^{-\cdots}$ & 20JULOA & $0^{-\cdots}$ & \\
\hline 138300 & 5 & 21JULOT' & 25JULO $\cdots$ & 0 & \\
\hline 13830E1 & 5 & $26 J U 101^{\cdots+\cdots}$ & 30JULO1 & $--0^{--}$ & \\
\hline $13830 \mathrm{~F}$ & 3 & 31.JULO1 & O2AUG01 & - & \\
\hline$-13830 \mathrm{G}$ & $30 \cdots$ & O3AUGO1 - & O1SEPOT & $0^{-}$ & \\
\hline 13B30H & 8 & O2SEPOH & OSSEPO1 & $0-$ & \\
\hline $13 \mathrm{~B} 30 \mathrm{~J}$ & 8 & $\because$ TOSEPO1 & 17SEP01 & 2 & \\
\hline \multicolumn{5}{|c|}{ 130.840 Perform Bootstrap Transfers } & \multirow{10}{*}{ Perform Xfer Flush Water from 2AP to $6 A P$ ) } \\
\hline $13 \mathrm{~B} 40 \mathrm{C} 2$ & 9 & 10MAYO1 $\cdots$ & ¿8MAYOH & $46 \cdots$ & \\
\hline $13840 \mathrm{~B} 2$ & 12 & 10MAYOS $\cdots$ & 21MAY01- & -24 & \\
\hline 1384002 & 4 & 221.AYYOA & 25KAY $01^{-\cdots}$ & 24 & \\
\hline 1384003 & $5^{\circ}$ & 26MAYOT $\cdots$ & 31MAY01 & $-\cdots 24 \cdots$ & \\
\hline $13 B 40 A 1$ & 20 & 10MAYOY & OYJUNO1 ${ }^{\prime}$ & $-3 \cdots$ & \\
\hline $13 B 40 A 2$ & 12 & OBJUN01 & 19JUNO1 & -5 & \\
\hline$\{3840 E 2$ & 5 & 20JUNA1 & 24JUNO1 & 5 & \\
\hline 13B40E3 & 4. & 25.JUNO1 & 28JUNO1 & 5 & \\
\hline $13840 \mathrm{~F} 2$ & 5 & 29.JUNOT & O3JULO & 5 & \\
\hline \multicolumn{5}{|c|}{ 130.B45 Prepare for Sampling During LAWW Feed Staging } & \multirow{9}{*}{ GTralu Sámpling Persomel in New Procedures } \\
\hline $13 \mathrm{~B} 45 \mathrm{~A} \cdots$ & $\$ 4$ & -27 MAY98 & $29 \mathrm{JUL} 98$ & $37^{-1}$ & \\
\hline $13045 \mathrm{~J} \cdots \cdots$ & $70^{\cdots}$ & $30 \mathrm{JUL} 98^{-\cdots}$ & 05NOV98-- & $-37^{---}$ & \\
\hline $13845 Q$ & 140 & O6NOV98 $\cdots \cdot$ & 28MAY99 & 37 & \\
\hline $13845 \mathrm{~K}^{-}$ & $30 \cdots$ & O1JUN99-- & $14 J U L 99^{-\ldots}$ & $-37^{-\cdots}$ & \\
\hline $13045 L$ & 255 & 15JUL.99- & 19JULO0 & $-37^{---}$ & \\
\hline 1384514 & 90 & 20 JUL.00 & $\cdots 27$ NOV00 & 37 & \\
\hline $13 B 45 \mathrm{~N}$ & 22 & 28 NOVOO $\cdots$ & 290ECOO & $-3 y$ & \\
\hline $13 \mathrm{~B} 45 \mathrm{P}$ & .44 & 02JAN01. & O5MAR01 & $\cdots 37^{\cdots}$ & \\
\hline
\end{tabular}




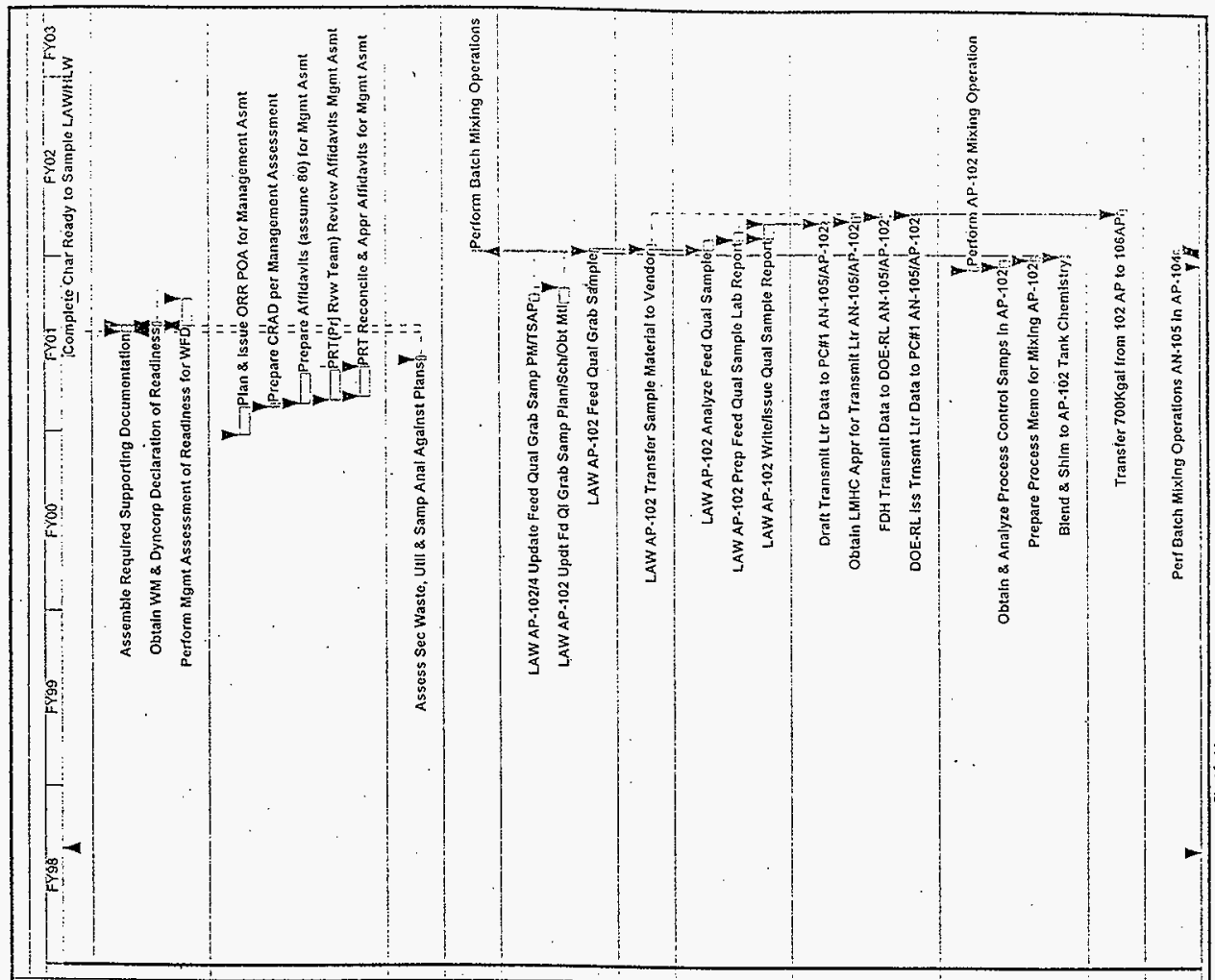

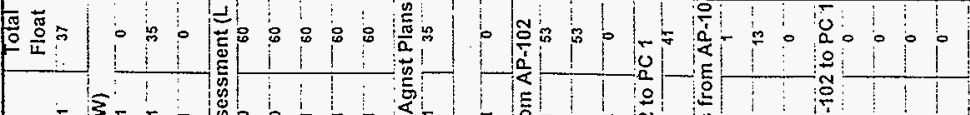

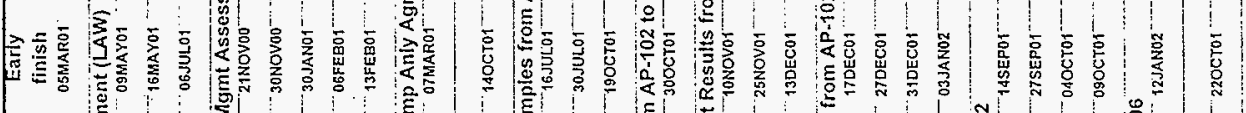

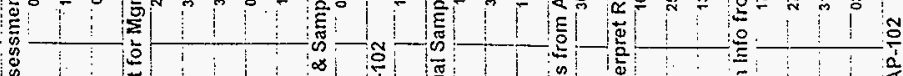

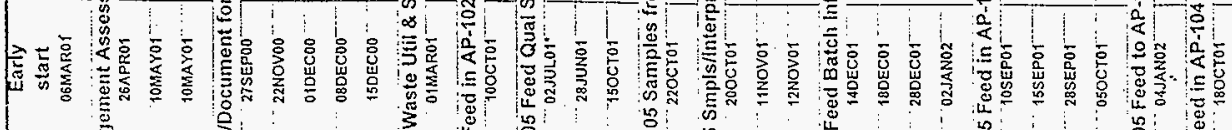

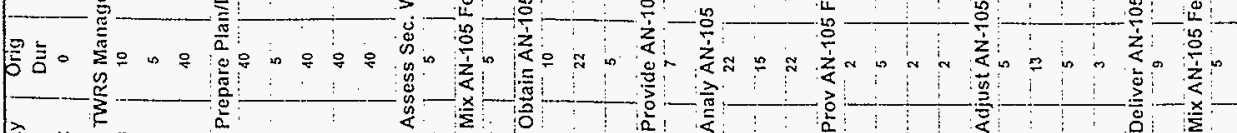

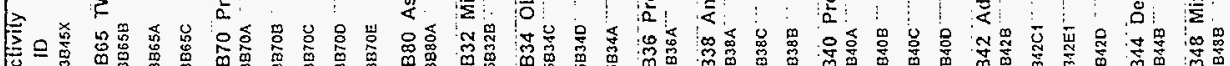
ए人 


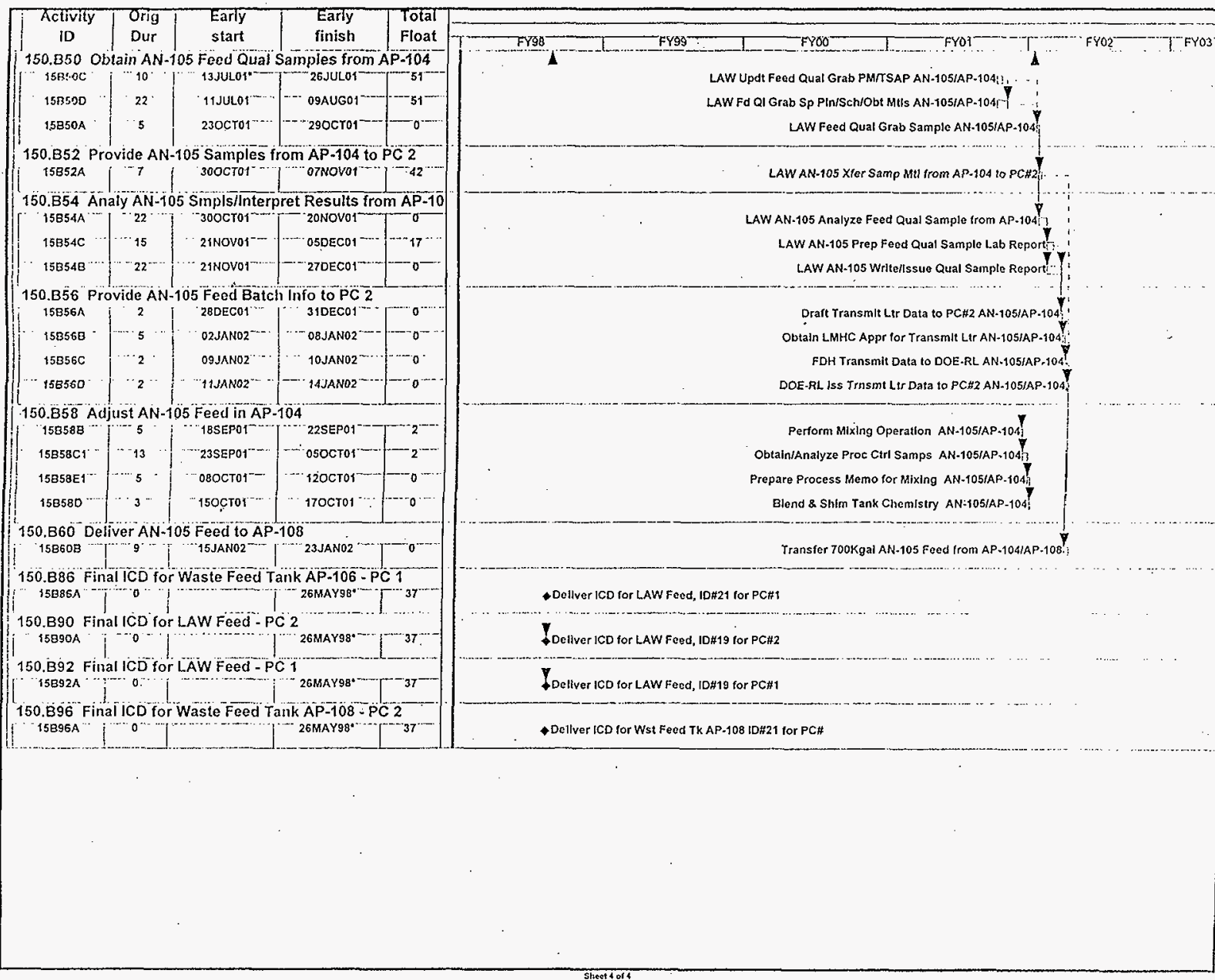




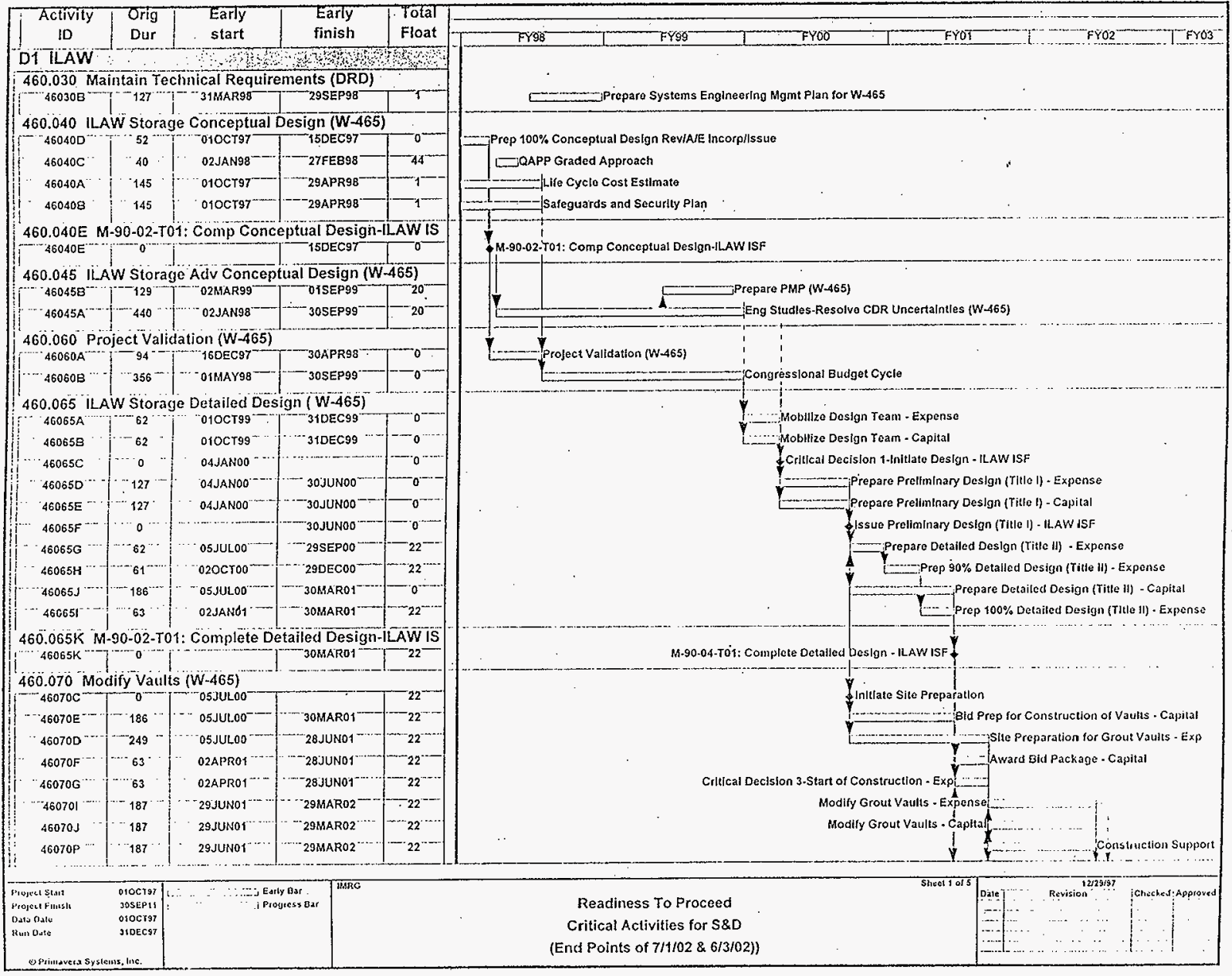




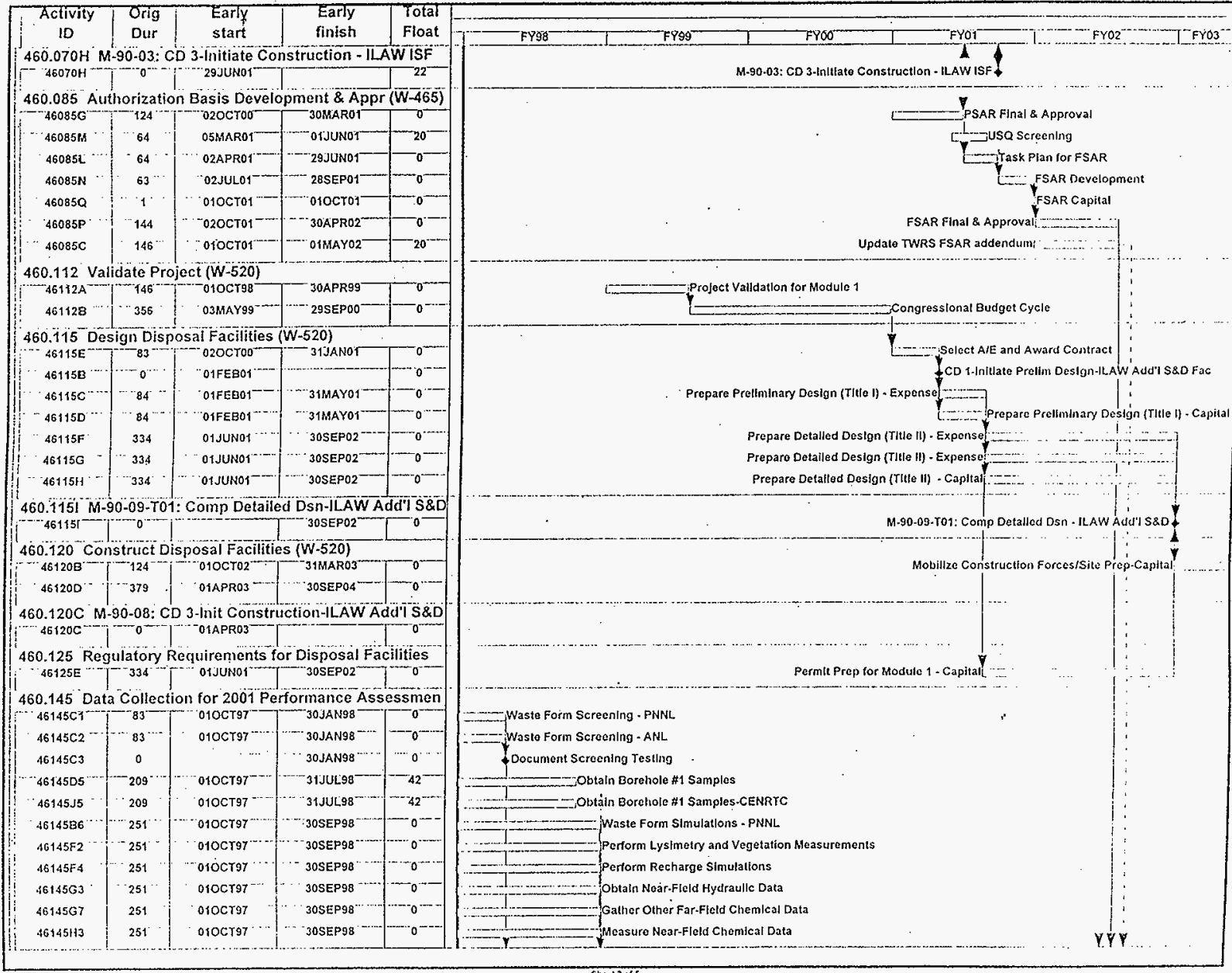




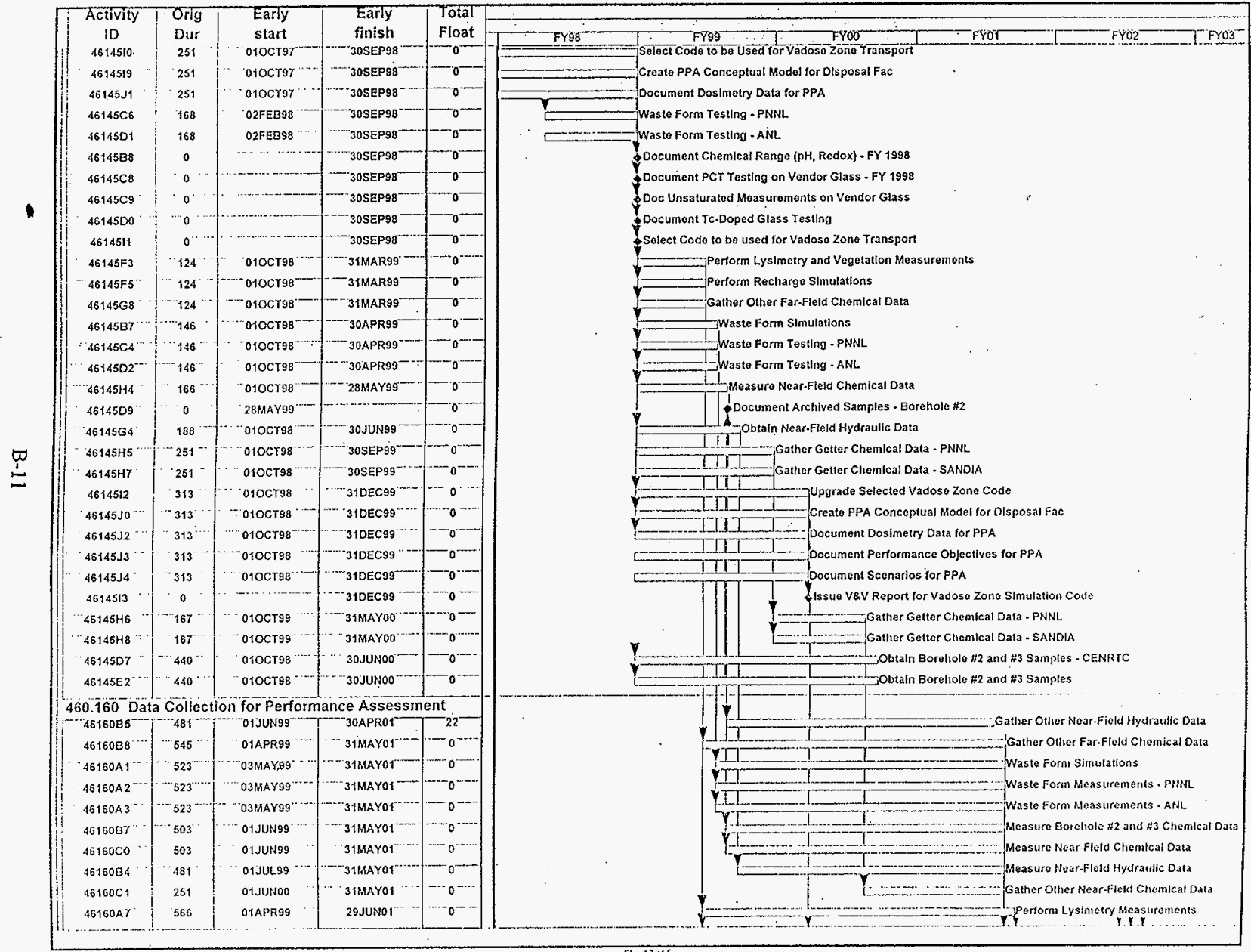




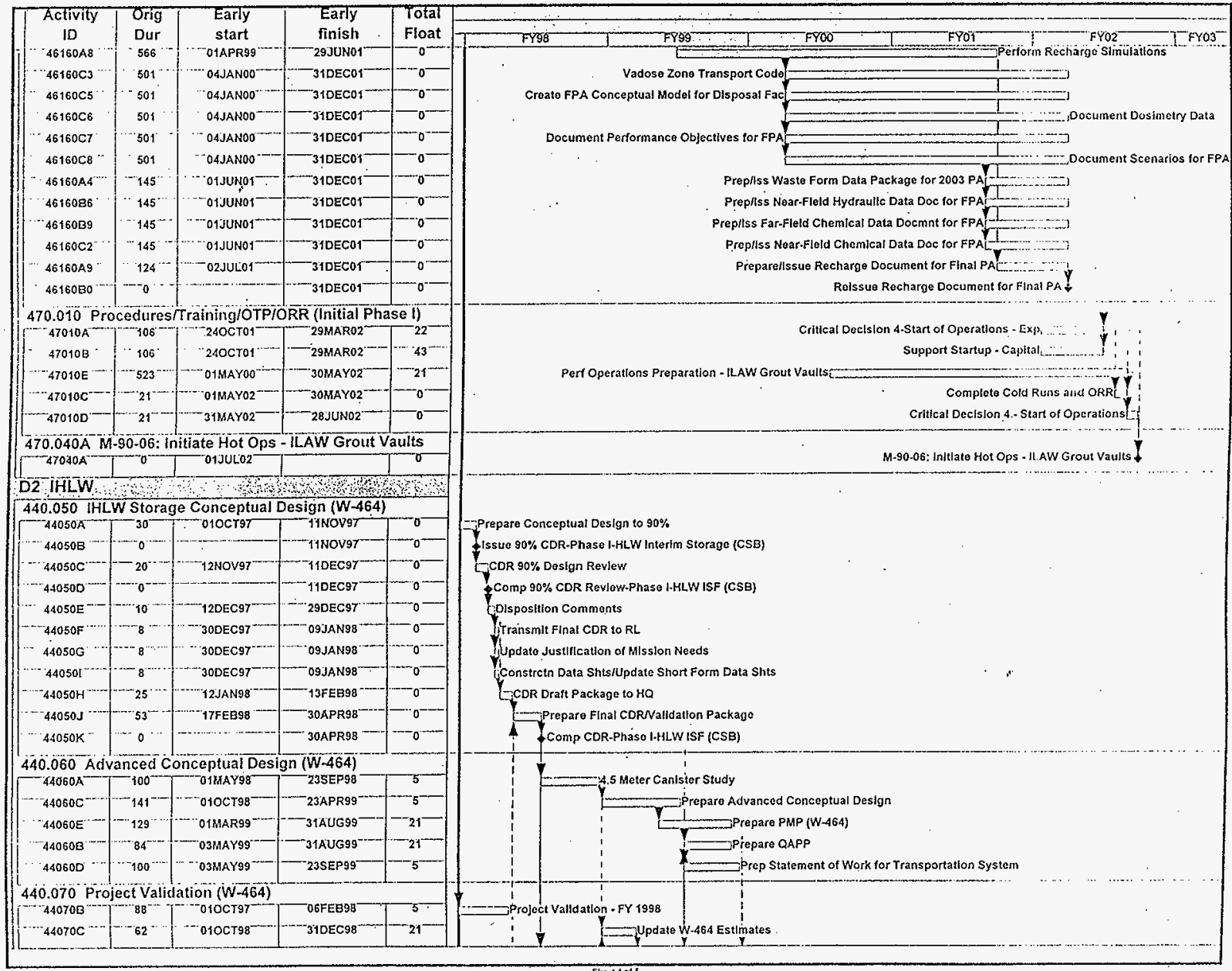




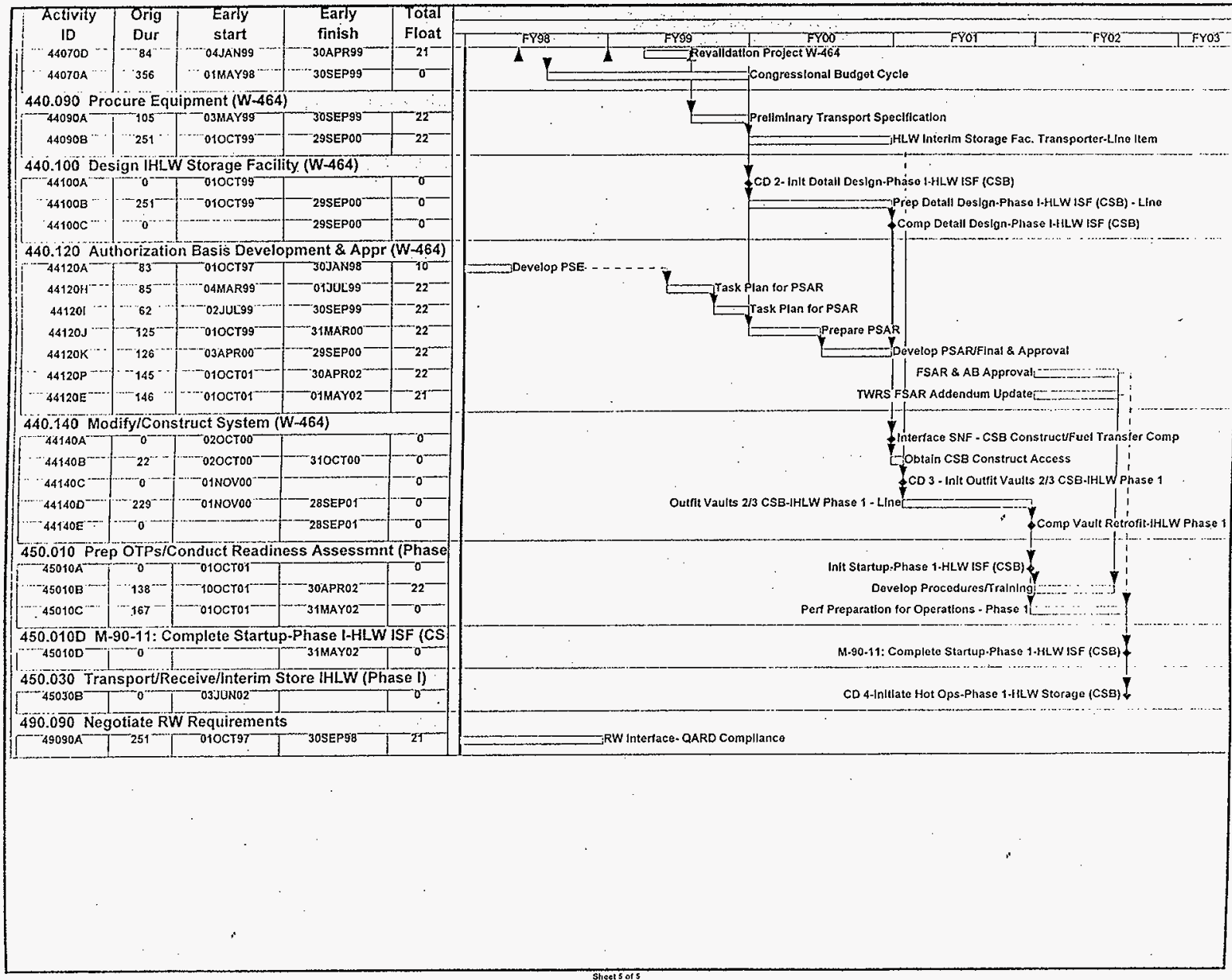




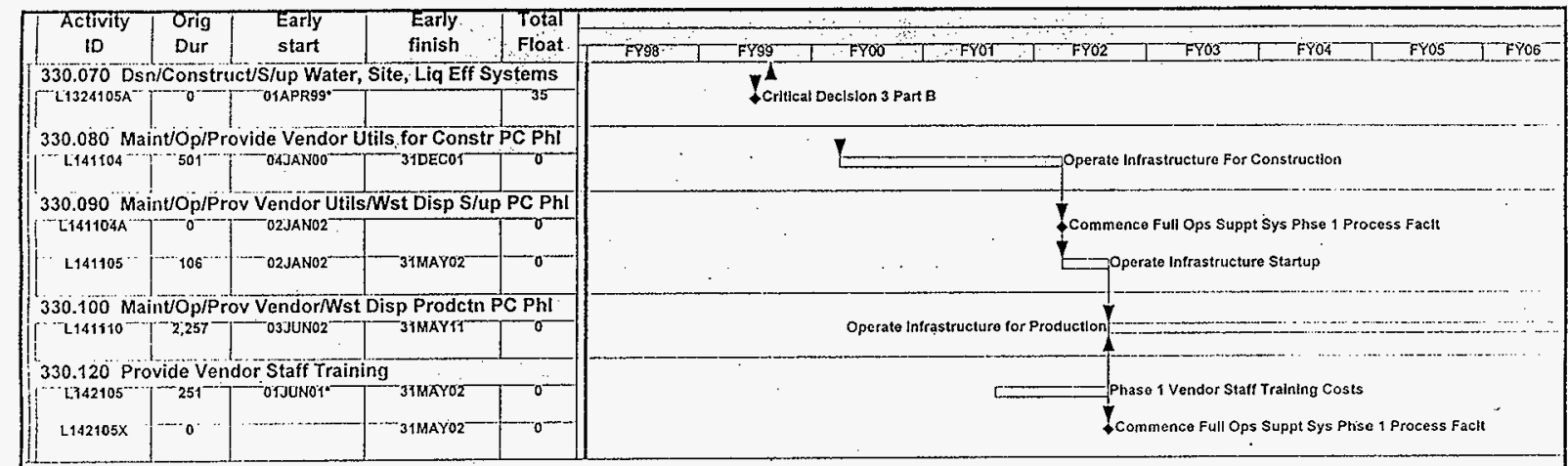


HNF-2017 Rev 0

This page intentionally left blank. 


\section{HNF-2017 Rev 0}

\section{APPENDIX C}

\section{GUIDANCE AND REQUIREMENTS TO}

DELIVERABLES CROSSWALK

TWRS Retrieval and Disposal Mission

Phase 1 Financial Analysis 
HNF-2017 Rev 0

This page intentionally left blank. 
Table C-1. Guidance and Requirements to Deliverables Crosswalk - Retrieval and Disposal Mission Phase 1 Financial Analysis.

\begin{tabular}{|c|c|c|}
\hline \multirow{2}{*}{$\begin{array}{l}\text { Guidance or Requirement } \\
\text { A.1 DOE Letter to H. J. Hatch, FDH, from W J } \\
\text { Taylor, DOE, dated August 8, 1997, \#9757162A } \\
\text { (36 ITEM CHECKLIST) }\end{array}$} & Status & Implementing Location \\
\hline & & \\
\hline $\begin{array}{l}\text { 23. The critical path is identified and float has been } \\
\text { calculated. }\end{array}$ & I & Section 4.4 \\
\hline 24. Activities have been properly funded. & $\mathrm{I}$ & Section 4.5 \\
\hline $\begin{array}{l}\text { 25. Analysis of budget against resource requirements } \\
\text { has been completed. }\end{array}$ & $I$ & HNF 2017, Section 4.7 \\
\hline $\begin{array}{l}\text { 26. There is agreement among scope, budget, and } \\
\text { schedule. The scope of work can be performed within } \\
\text { budget and on schedule. }\end{array}$ & I & Section 4.4 \\
\hline $\begin{array}{l}\text { 27. Schedule risk has been identified and is being } \\
\text { managed. }\end{array}$ & I & Section 4.4 \\
\hline $\begin{array}{l}\text { 36. The PMHC team has prepared a readiness-to- } \\
\text { proceed memorandum and has identified deficiencies } \\
\text { and corrective actions, including funding, necessary to } \\
\text { support privatization. }\end{array}$ & $\mathrm{I}$ & Sections 4.5 and 5.0 \\
\hline $\begin{array}{l}\text { A.2 DOE Letter to H. J Hatch, FDH, from W, J. } \\
\text { Taylor, DoE, dated August } 8,1997, \# 975762 \mathrm{~A} \\
\text { (BODY OF TEXT) }\end{array}$ & & \\
\hline \multicolumn{3}{|l|}{$\begin{array}{l}\text { General PHMC Responsibilities from RL's 8/8/97 } \\
\text { letter, Section 2.1 }\end{array}$} \\
\hline $\begin{array}{l}\text { 5. Costs and schedules in the programmatic baseline } \\
\text { can be met }\end{array}$ & I & Section 4.4 \\
\hline $\begin{array}{l}\text { 6. Critical path analysis is done to determine the } \\
\text { impacts of budget shortfalls on the programmatic } \\
\text { baseline }\end{array}$ & I & Sections 4.4 and 4.5 \\
\hline \multicolumn{3}{|l|}{$\begin{array}{l}\text { A.3 DOE Letter H. J Hatch, FDH, from William J. } \\
\text { Taylor, DOE, dated December 2, 1997, } \$ 9761291\end{array}$} \\
\hline $\begin{array}{l}\text { 6. RTP deliverables and their support must address the } \\
\text { readiness of supporting facilities outside of TWRS, } \\
\text { and understand FDH's readiness to receive secondary } \\
\text { wastes. }\end{array}$ & I & Sections 4.4 and 4.5 \\
\hline
\end{tabular}


Table C-1. Guidance and Requirements to Deliverables Crosswalk - Retrieval and Disposal Mission Phase 1 Financial Analysis.

\begin{tabular}{|c|c|c|}
\hline Guidance or Requirement & Status & Implementing Location \\
\hline $\begin{array}{l}\text { B.1 DOE Order 430.1, Good Practice Guide, } \\
\text { GPG-FM-002 }\end{array}$ & $\%$ & $(4,4)$ \\
\hline \multicolumn{3}{|l|}{ 2.2.4 Baseline: Cost Criteria } \\
\hline 1. Total Estimated Cost (TEC) & $\mathrm{I}$ & Section 3.0 \\
\hline 2. Life Cycle Cost (LCC) & $\mathrm{I}$ & Section 3.0 \\
\hline 2.3.2 Funding Profile & $\mathrm{I}$ & Sections 3.0 and 4.0 \\
\hline \multicolumn{3}{|l|}{ 2.3.4 Baseline: Cost Criteria } \\
\hline 1. Total Estimated Cost (TEC) & I & Sections 3.0 and 4.0 \\
\hline 2. Total Project Cost (TPC) & I & Sections 3.0 and 4.0 \\
\hline 3. Life Cycle Cost (LCC) & I & Sections 3.0 and 4.0 \\
\hline 2.4.2 Funding Profile & $\mathrm{I}$ & Sections 3.0 and 4.0 \\
\hline \multicolumn{3}{|l|}{ 2.4.4 Baseline: Cost Criteria } \\
\hline 1. Total Estimated Cost (TEC) & $\mathrm{I}$ & Section 3.0 and 4.0 \\
\hline 2. Total Project Cost (TPC) & $\mathrm{I}$ & Section 3.0 and 4.0 \\
\hline 3. Life Cycle Cost (LCC) & I & Sections 3.0 and 4.0 \\
\hline \multicolumn{3}{|l|}{ 2.5.4 Baseline: Cost Criteria } \\
\hline 1. Life Cycle Cost (LCC) & 1 & Sections 3.0 and 4.0 \\
\hline \multicolumn{3}{|l|}{$\begin{array}{l}\text { D. } 1 \text { Detailed Instructions for Assessment of RTP } \\
\text { Appendix C, November } 14,1997\end{array}$} \\
\hline $\begin{array}{l}\text { 4. Provide confirmable critical path and float activities } \\
\text { not on the path }\end{array}$ & I & Section 4.4 \\
\hline $\begin{array}{l}\text { 6. Identify those activities most at risk for meeting the } \\
\text { June, } 2002 \text { hot start }\end{array}$ & - I & Section 4.2 \\
\hline $\begin{array}{l}\text { 11. Identify activities most at risk in schedules and } \\
\text { logic diagrams (for infrastructure). }\end{array}$ & I & Sections 4.2 and 4.4 \\
\hline $\begin{array}{l}\text { 12. Identify projects that directly support } \\
\text { infrastructure, based on project plans. }\end{array}$ & I & see HNF-1882 (INFBAS Plan) \\
\hline $\begin{array}{l}\text { 16. Show an ability to meet all schedules needed by } \\
\text { the private contractors for receiving immobilized LAW } \\
\text { and HLW and separated cesium. }\end{array}$ & $\mathrm{I}$ & Section 4.4 \\
\hline $\begin{array}{l}\text { 17. Identify activities most at risk in schedules and } \\
\text { logic diagrams (for ILAW, IHLW, and Cesium). }\end{array}$ & I & Sections 4.2 and 4.4 \\
\hline
\end{tabular}


Table C-1. Guidance and Requirements to Deliverables Crosswalk - Retrieval and Disposal Mission Phase 1 Financial Analysis.

\begin{tabular}{|c|c|c|}
\hline \multirow{2}{*}{$\begin{array}{l}\text { Guidance or Requirement } \\
\text { D.3 Plan for Determining PHMC-Team's RTP for } \\
\text { Waste Feed Delivery - Document Checklist } \\
\text { (Table 3) }\end{array}$} & \multirow[t]{2}{*}{ Status } & \multirow[t]{2}{*}{ Implementing Location } \\
\hline & & \\
\hline $\begin{array}{l}\text { 58. Plans describe reassessing the timing and needs } \\
\text { for procurement of additional mixer pumps for DSTs, } \\
\text { considering the need dates and availability of advanced } \\
\text { mixer-pump designs. }\end{array}$ & I & Section 4.1 \\
\hline $\begin{array}{l}\text { D.5 Draft Plan for Determining RTP for } \\
\text { Infrastructure \& Byproducts Delivery }\end{array}$ & & \\
\hline $\begin{array}{l}\text { 4. Provide confirmable critical path and float activities } \\
\text { not on the path. }\end{array}$ & I & Section 4.4 \\
\hline $\begin{array}{l}\text { D.7 Draft Plan for Determining RTP for } \\
\text { Infrastructure \& Byproducts Delivery, Appendix B, } \\
\text { Programmatic Baseline Checklist. }\end{array}$ & +क & \\
\hline $\begin{array}{l}\text { 33. Provide Economic Analyses and Life Cycle Cost } \\
\text { analyses, and Independent Cost Estimates. (2.3.3- } \\
\text { 2.3.4) }\end{array}$ & I & Section 2.1 \\
\hline $\begin{array}{l}\text { 35. Provide schedule risks and identify how schedules } \\
\text { are managed to reduce risk. }(2.5 .1-2.5 .7)\end{array}$ & I & Section 4.4 \\
\hline $\begin{array}{l}\text { D. } 10 \text { Draft Plan for Determining RTP for } \\
\text { Infrastructure \& Byproducts Delivery, } / \text { ppendix E, } \\
\text { Infrastructure Feed Tank Transfer (Programmatic } \\
\text { Baseline) Checklist. }\end{array}$ & & \\
\hline $\begin{array}{l}\text { 77. Provide Economic Analyses and Life Cycle Cost } \\
\text { analyses, and Independent Cost Estimates. (2.3.3- } \\
\text { 2.3.4) }\end{array}$ & I & Sections 2.1 \\
\hline $\begin{array}{l}\text { 79. Provide schedule risks and identify how schedules } \\
\text { are managed to reduce risk. }(2.5 .1-2.5 .7)\end{array}$ & I & Section 4.4 \\
\hline
\end{tabular}


Table C-1. Guidance and Requirements to Deliverables Crosswalk - Retrieval and Disposal Mission Phase 1 Financial Analysis.

\begin{tabular}{|c|c|c|}
\hline \multirow{2}{*}{$\begin{array}{l}\text { Guidance or Requirement } \\
\text { E.1 TWRS Waste Disposal Division Planning } \\
\text { Guidance dated July } 7,1997 \text { (Updated December } \\
12,1997 \text { ) }\end{array}$} & Status & Implementing Location \\
\hline & & \\
\hline $\begin{array}{l}\text { Prioritize budget according to } 2.2 .1 \text { (privatization } \\
\text { highest, LLW over HLW, finish projects over new } \\
\text { starts, demonstrate an early success with a tank } \\
\text { closure.) }\end{array}$ & I & Section 2.1 and 4.0 \\
\hline $\begin{array}{l}\text { Alternative strategies, risk reduction, core } \\
\text { competencies and capsule disposition, closure get } \\
\text { lowest budget priority }\end{array}$ & $I$ & Sections 4.2 and 4.3 \\
\hline $\begin{array}{l}\text { Add sufficient detail in schedules to define critical path } \\
\text { and logical sequences. }\end{array}$ & I & Section 4.4 \\
\hline $\begin{array}{l}\text { (Projects) identify the impact of funding shortfall on } \\
\text { mission. }\end{array}$ & I & Sections 4.5 and 5.0 \\
\hline $\begin{array}{l}\text { Waste Retrieval Project will plan for the } 10 \text { Phase } 1 \\
\text { items in paragraph 3.2.l. }\end{array}$ & I & Section 3.0 \\
\hline $\begin{array}{l}\text { Waste Retrieval Project will assume the } 11 \text { items in } \\
\text { paragraph 3.2.2. }\end{array}$ & $\mathrm{I}$ & Section 3.0 \\
\hline
\end{tabular}




\begin{tabular}{|c|c|c|c|c|c|}
\hline \multicolumn{6}{|c|}{ DISTRIBUTION SHEET } \\
\hline \multirow{2}{*}{ Do } & \multirow{2}{*}{\multicolumn{3}{|c|}{$\begin{array}{l}\text { From } \\
\text { TWRS Configuration Management }\end{array}$}} & \multicolumn{2}{|c|}{ Page Fof i } \\
\hline & & & & \multicolumn{2}{|c|}{ Date January 3,1998} \\
\hline \multirow{2}{*}{\multicolumn{4}{|c|}{$\begin{array}{l}\text { Project Title/Work Order } \\
\text { Tank Waste Remediation Systems }(\text { HNF-2017) }\end{array}$}} & \multirow{2}{*}{\multicolumn{2}{|c|}{$\begin{array}{l}\text { EDT No. } \quad 622747 \\
\text { ECN No. }\end{array}$}} \\
\hline & & & & & \\
\hline Name & MSIN & $\begin{array}{c}\text { Text } \\
\text { With All } \\
\text { Attach. }\end{array}$ & $\begin{array}{l}\text { Text } \\
\text { Only }\end{array}$ & $\begin{array}{l}\text { Attach./ } \\
\text { Appendix } \\
\text { Only }\end{array}$ & $\begin{array}{l}\text { EDT/ECN } \\
\text { Only }\end{array}$ \\
\hline
\end{tabular}

J.N. Alibert

H.L. Boston

M.P. Delozier

M.D. Ebben

0. A. Halvorson

J.0. Honeyman

K.N. Jordan

R.A. Kirkbride

S.C. Klimper

M.R. Lewis

D.M. McDaniel

R.J. Murkowski

M.A. Payne

M.L. Peterman

R.W. Powe 17

R.E, Raymond

S.H. Rifaey

B. Root

P.S. Schaus

S.E. Seeman

S.J. Simon

W.R. Swita

R.L. Treat

J.M. Vann

J.H. Wicks Jr

R.D. Wojtasek
$\$ 2-48$

G3-21

R2-58

H7 -07

G3-21

G3-21

G3-21

H5-27

H6-25

H5-03

H7-06

H6-37

R2-58

H7- 06

H5- 03

R2-38

R1-56

G3-21

H5- 03

H6-35

H7-06

H5- 03

H5- 03

H6-37

H7-07

G3-21 $x$

2 copies

$x$

$x$

$x$

$x$

$x$

$x$

$x$

$x$

3 copies

3 copies

2 copies

$X$

$x$

$x$

$x$

$x$

$x$

$x$

$x$

$x$

2 copies

$x$

$x$

3 copies 